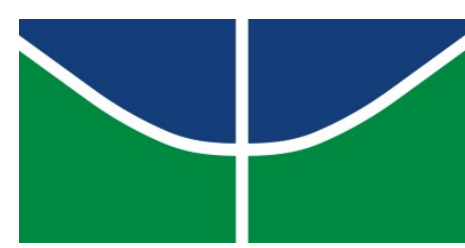

Universidade de Brasília

Instituto de Letras

Departamento de Teoria Literária e Literaturas

Programa de Pós-graduação em Literatura

\title{
O SONHO NA ESCRITA DE CECÍLIA MEIRELES E DE JORGE LUIS BORGES
}

Fabio Alcides de Souza

Orientador: Prof. Dr. José Luis Martinez Amaro 
Fabio Alcides de Souza

O SONHO NA ESCRITA DE CECÍLIA MEIRELES E DE JORGE LUIS BORGES

Dissertação apresentada ao Programa de PósGraduação em Literatura da Universidade de Brasília

Orientador:

Prof. Dr. José Luis Martinez Amaro 
Fabio Alcides de Souza

\section{O sonho na escrita de Cecília Meireles e de Jorge Luis Borges}

Dissertação apresentada ao Programa de Pós-Graduação do Departamento de Teoria Literária e Literaturas da Universidade de Brasília, como requisito parcial à obtenção do título de Mestre em Literatura, na linha de pesquisa Estudos Literários Comparados.

Banca Examinadora

Prof. Dr. José Luis Martinez Amaro - TEL/UnB

(Orientador e Presidente da Banca)

$\overline{\text { Prof. Dr. Augusto Rodrigues da Silva Junior - TEL/UnB }}$

(Membro)

Profa. Dra. Alicia Silvestre Miralles - LET/UnB

(Membro)

Prof. Dr. Erivelto da Rocha Carvalho - TEL/UnB

(Membro Suplente) 
Dedico este trabalho aos atuais estudantes que deveriam ser motivo de inspiração para todos. 


\section{AGRADECIMENTO}

Agradeço a todos que contribuíram na consecução deste trabalho, em especial ao orientador professor José Luis Martinez Amaro pelo apoio sempre solícito, e aos membros da banca de qualificação, professores Anna More e Erivelto Carvalho, cujas recomendações foram fundamentais para o aprimoramento do trabalho final.

Agradeço ainda aos demais membros da equipe do Programa de Pós-Graduação em Literatura da Universidade de Brasília, professores e servidores, e aos colegas discentes. 
Cada sonho é um existir de outro sonho (Álvaro de Campos) 


\section{RESUMO}

Referência: SOUZA, Fabio Alcides. O sonho na escrita de Cecília Meireles e de Jorge Luis Borges. 91fl. Literatura. Universidade de Brasília, Brasília, 2017.

O sonho, fenômeno presente na vida de todas as pessoas, é algo cuja explicação não é plenamente compreendida. O tema do sonho é frequente na Literatura e, historicamente, tem sido motivo de diversas interpretações filosóficas, científicas e culturais, especialmente no âmbito das religiões. Na América do Sul, durante o século XX, a temática do sonho foi utilizada pelos escritores Cecília Meireles e Jorge Luis Borges em vários de seus textos, de maneira recorrente. A partir da perspectiva dos estudos literários comparados, este trabalho aborda a temática do sonho no universo literário, mas também em outras áreas do conhecimento, utilizando as várias percepções sobre o tema como subsídio para a análise das obras de ambos os escritores sul-americanos, especialmente, no que se refere à oposição sonho e realidade.

Palavras-chave: Sonho. Realidade. Cecília Meireles. Jorge Luis Borges. 


\begin{abstract}
Reference: SOUZA, Fabio Alcides. The dream in the writing of Cecília Meireles and Jorge Luis Borges. 91 pg. Literature. Universidade de Brasília, Brasília, 2017.

The dream is something whose explanation is not fully understood. The theme of the dream is recurrent in literature and, historically, has been the subject for various philosophical, scientific and cultural interpretations, especially in the scope of the religions. In South America during the twentieth century, the theme of the dream was used by writers Cecília Meireles and Jorge Luis Borges in several of their texts. From the perspective of comparative literary studies, this work approaches the theme of the dream in the literary universe, but also in other areas of knowledge, using the various perceptions about the theme as subsidy for the analysis of the works of both South American writers, especially, as regards opposition dreams and reality.
\end{abstract}

Keywords: Dream. Reality. Cecília Meireles. Jorge Luis Borges. 


\section{SUMÁRIO}

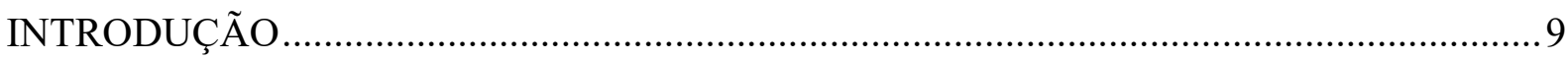

CAPÍTULO 1 - SONHOS NOS ESTUDOS LITERÁRIOS COMPARADOS ........................ 13

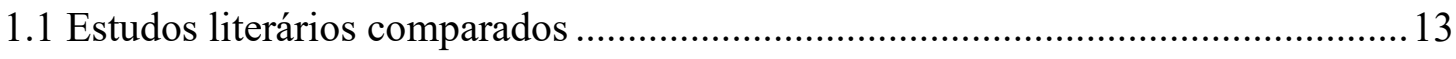

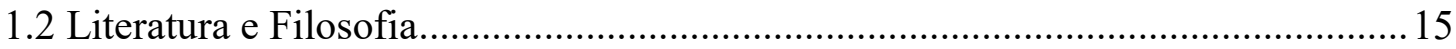

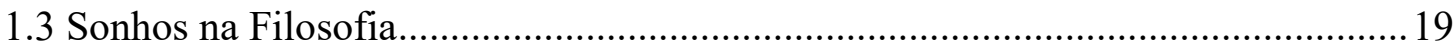

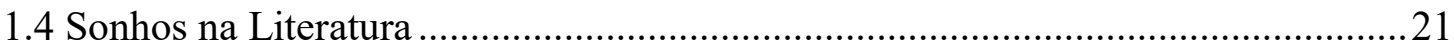

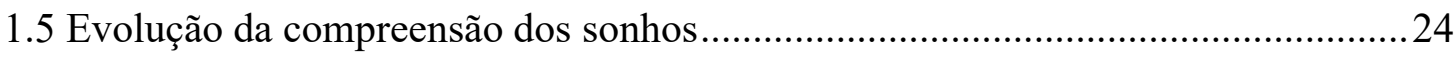

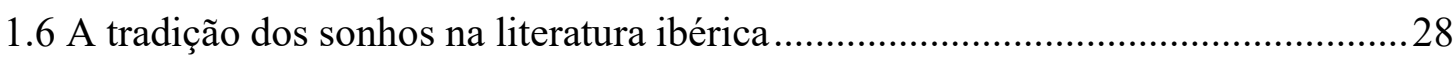

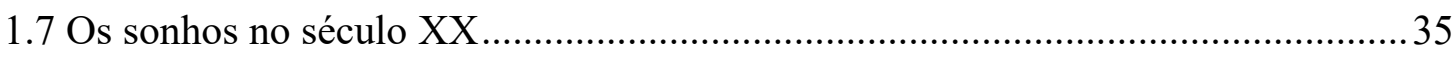

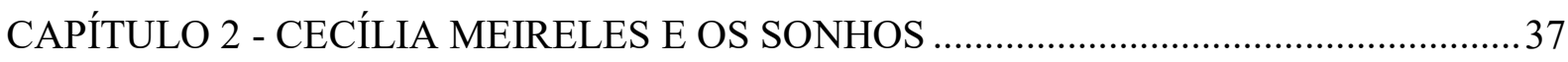

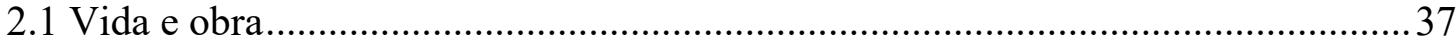

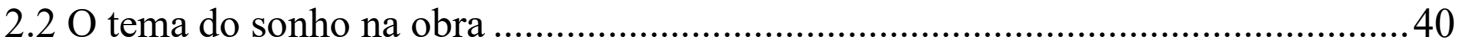

CAPÍTULO 3 - A POÉTICA DOS SONHOS EM JORGE LUIS BORGES ..........................48

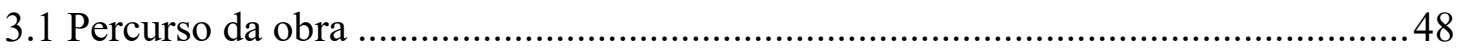

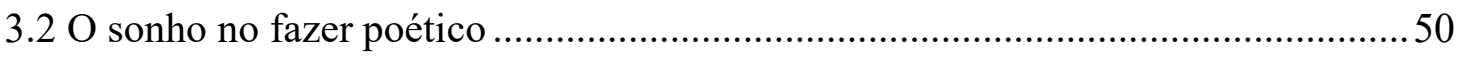

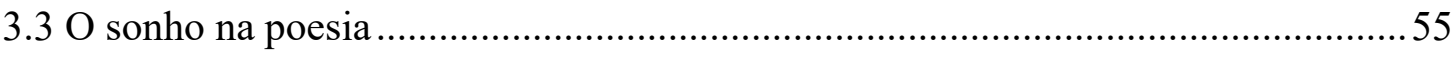

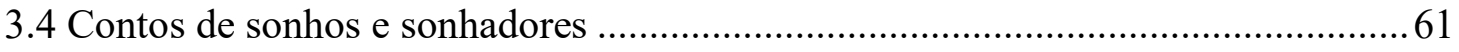

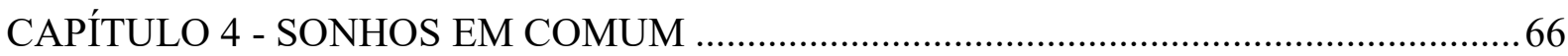

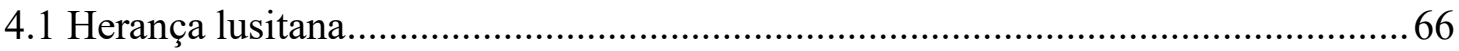

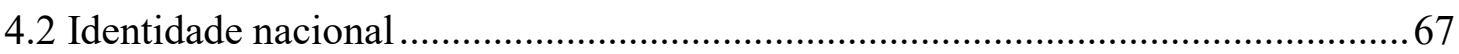

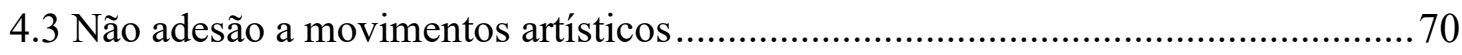

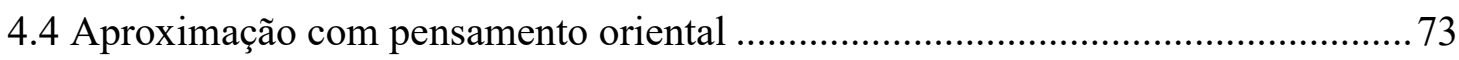

4.5 Relação com ideias de Schopenhauer ................................................................... 77

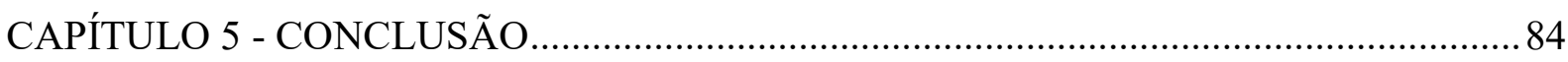

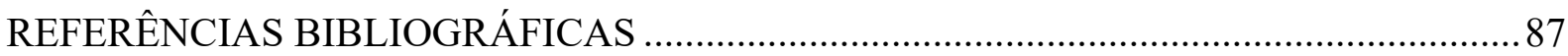




\section{INTRODUÇÃO}

O sonho é elemento presente na vida do ser humano, seja durante o sono, ou no período da vigília, a experiência do sonho é algo inerente a todas as pessoas. Experiência que pode ser alegre ou triste, parecer real ou totalmente absurda, e cuja interpretação está associada a fatores culturais, que variam conforme a região, o momento histórico, o desenvolvimento científico de cada povo ou civilização.

$\mathrm{Na}$ Literatura, de forma geral, referências a sonhos são recorrentes, passando por obras clássicas como Odisséia e Eneida, peças de Shakespeare, Dom Quixote, dentre muitas outras, sendo O Sonho de Cipião, episódio constante do livro De Republica, de Cícero, considerado "pela crítica" um precursor do modelo de sonho literário (TRUEBA, 1999, p.30).

$\mathrm{Na}$ Literatura Brasileira, a poeta Cecília Meireles, cuja obra apresenta como um dos seus traços distintivos um certo distanciamento da realidade, tratou diretamente desta temática em poemas escritos no período de 1950 a 1963, e posteriormente organizados e publicados na antologia denominada Poesia Completa. O sonho, entretanto, se apresenta como tema em sua obra desde seu primeiro livro Espectros de 1919.

A importância da poesia de Cecília Meireles é reconhecida por críticos, como Alfredo Bosi e Otto Maria Carpeaux, além de diversos autores brasileiros dela contemporâneos, como Carlos Drummond de Andrade, Mário de Andrade e Manuel Bandeira. Em artigo sobre o livro Viagem, publicado em 1939, Mário de Andrade, um dos principais nomes do movimento modernista brasileiro, escreveu:

\footnotetext{
Por todas as tão diversas conceituações e experiências de poesia que apareceram no movimento literário brasileiro do Modernismo pra cá, Cecília Meireles tem passado, não exatamente incólume, mas demonstrando firme resistência a qualquer adesão passiva. Ela é desses artistas que tiram seu ouro onde o encontram, escolhendo por si, com rara independência. E seria este o maior traço da sua personalidade, o ecletismo, se ainda não fosse maior o misterioso acerto, dom raro, com que ela se conserva sempre dentro da mais íntima e verdadeira poesia. (ANDRADE, 2012, p.156)
}

O poeta Carlos Drummond de Andrade, ao escrever sobre Cecília Meireles, também ressaltou a obra singular e independente dos estilos de época, a tal ponto diferenciada que "não é de estranhar que a achássemos diferente do retrato comum dos poetas e das mulheres"; e conclui que a poesia ceciliana é "sem paridade no quadro da língua, pela síntese vocabular e fluidez de atmosfera" (ANDRADE, 1964, p.6). 
$\mathrm{Na}$ Literatura Hispanoamericana, o argentino Jorge Luis Borges utilizou o elemento do sonho de forma recorrente em seus contos e poemas, oferecendo uma percepção em que sonhos e devaneios funcionam como criadores de realidades. De forma semelhante à escritora brasileira, Borges também tratou do tema desde seu primeiro livro de poesia Fervor de Buenos Aires, publicado em 1923.

Comumente considerado um dos principais autores do século XX, Jorge Luis Borges produziu uma obra livre dos estilos de época, e que possui grande destaque no âmbito da literatura produzida no mundo ocidental. Se hoje é reconhecido mundialmente, no Brasil, ainda no ano de 1928, o já citado Mário de Andrade escreveu um artigo em que exaltava a obra inicial de Borges, e já previa seu êxito futuro.

\footnotetext{
Este poeta e ensaísta me parece a personalidade mais saliente da geração moderna da Argentina. Depois de Ricardo Güiraldes - o que teve a felicidade de morrer depois da obra-prima - a figura de Jorge Luis Borges é a que mais me atrai e me parece mais rica de lá. Será talvez ele quem vai substituir Ricardo Güiraldes e consolar com uma presença de intimidade a memória do morto. (ANDRADE, 2001, p.284)
}

Cecília Meireles e Jorge Luis Borges são, portanto, dois autores que compartilharam a mesma época, o mesmo continente, a mesma temática. E ao observar as opiniões de Mário de Andrade - um escritor fortemente ligado ao movimento modernista brasileiro - verifica-se que a independência de estilo das obras dos dois autores não impossibilitou a apreciação de seu valor.

O objetivo deste trabalho é analisar e confrontar obras dos escritores Cecília Meireles e Jorge Luis Borges que tratem da temática do sonho e suas representações. Além dos aspectos literários, serão apresentados também possíveis diálogos com filosofias e pensamentos pertinentes, que porventura possam ser úteis para a análise.

A partir da leitura de textos de Cecília Meireles, crônicas e poemas, se pretende verificar a oposição entre sonho e realidade, na obra da poeta brasileira. E, no que se refere a Jorge Luis Borges, serão utilizados poemas, contos, alguns ensaios publicados pelo escritor sobre o tema, além de depoimentos concedidos em entrevistas.

No primeiro capítulo, a partir da utilização de alguns textos teóricos - de teorias literárias e filosóficas - serão apresentados alguns elementos que possibilitem o emprego de pensamentos e conceitos de outras áreas do conhecimento como forma de subsídio para o entendimento dos textos estudados, tendo em vista aspectos considerados no âmbito dos estudos literários comparados. 
O objetivo desta exposição inicial é propiciar um diálogo entre obras e teorias; diálogo no qual possa haver aproximações ou não, mas sempre tentando evitar que sejam estabelecidos critérios de ascendência entre as disciplinas estudadas, ou entre estas disciplinas e a obra em análise.

Serão elencados alguns dos conceitos existentes em áreas do conhecimento humano, que tratem da temática do sonho e do devaneio, especialmente no que se refere a espaços de criação de novas realidades em confronto com a realidade vivida durante o período da vigília, na perspectiva da concepção de experiências artísticas que tenham ênfase no imaginário surgido ou possibilitado pelo elemento onírico.

Além disso, são expostos aspectos históricos e culturais que possibilitem observar as raízes culturais do tema desde os países ibéricos, como forma de apresentar o percurso do tema até os autores aqui estudados, e o momento vivido na primeira metade do século XX.

O segundo capítulo trata, de forma breve, de aspectos da obra da poeta Cecília Meireles, traçando, em linhas gerais, algumas de suas características mais comuns. Neste capítulo, haverá também a apresentação de aspectos cronológicos e biográficos, que permitam ao leitor que já não possua um conhecimento prévio, uma breve percepção da vida e obra da poeta carioca.

Por intermédio da análise dos poemas Sonhei um sonho, Em sonho anunciam a minha morte e Aqui estou nos vales da terra de Cecília Meireles, se busca estabelecer algumas linhas de entendimento sobre a maneira como o tema do sonho se apresenta nestes poemas, suas formas de representação, e possíveis relações dos aspectos existentes com teorias filosóficas e literárias, anteriormente apresentadas, de forma a ampliar as possibilidades de estudo da obra poética.

O terceiro capítulo tem por objetivo demonstrar que a utilização dos sonhos na obra de Jorge Luis Borges seria parte da sua poética. O sonho seria um dos vários elementos recorrentes utilizados pelo escritor na elaboração de seus textos, que agregados a referências a teorias e pensamentos de ordem filosófica ou mesmo religiosa compõem uma espécie de identidade de suas poesias e contos.

O capítulo apresenta ainda poemas e contos de Borges em que o sonho é o tema principal. Desde seu primeiro livro de poesia Fervor de Buenos Aires de 1923, o escritor escreveu sobre o tema, e aqui serão analisados poemas de Jorge Luis Borges publicados a partir da década de 1960, além de dois contos As ruínas circulares e Everything and nothing, em que o sonho é elemento fundamental no tema das narrativas. 
O quarto capítulo estabelece relações entre obras dos escritores Cecília Meireles e Jorge Luis Borges, buscando associações e diferenças na abordagem do tema do sonho. Há não só referências a alguns outros poemas e contos dos autores, mas também a possíveis influências compartilhadas por ambos, dentro da perspectiva dos estudos literários comparados.

Finalmente, o último capítulo apresenta uma conclusão, na qual serão retomados alguns pontos apresentados, de forma a compor um relacionamento entre as partes anteriores, concedendo ao leitor uma percepção geral dos assuntos anteriormente expostos com o objetivo de permitir uma breve recapitulação da temática do sonho nas obras de Cecília Meireles e Jorge Luis Borges que foi exposta no decorrer deste estudo. 


\section{CAPÍTULO 1}

\section{SONHOS NOS ESTUDOS LITERÁRIOS COMPARADOS}

Inicialmente, é essencial estabelecer linhas teóricas que possibilitem a associação de ideias de outras disciplinas e aspectos culturais no âmbito da análise literária. Como forma de introduzir o assunto, apresenta-se então o conceito estabelecido por Henry H. Remak, que define, em linhas gerais, o objeto de estudo da chamada Literatura Comparada:

a literatura comparada é o estudo da literatura além das fronteiras de um país específico e o estudo das relações entre, por um lado, a literatura e, por outro, diferentes áreas do conhecimento e da crença, tais como as artes, a filosofia, a história, as ciências sociais, a religião etc. (REMAK, 2011, p.189)

\subsection{Estudos literários comparados}

Os estudos literários comparados permitem, portanto, a busca pela eliminação de barreiras, sejam as impostas pelas divisões geográficas, sejam aquelas estabelecidas pela divisão das ciências ou áreas do conhecimento; "é uma visão globalizante da literatura, do mundo das letras, uma ecologia humanística, [...] uma visão do universo cultural, englobante e abrangente" (JOST, 2011, p.353).

Dentro deste universo, questões como influência e intertextualidade são importantes para o balizamento dos estudos literários comparados. Numa tentativa de conceituação breve, a influência estaria ligada a uma forçosa hierarquia entre o criador atual e aquele que o influenciou - seja positiva ou negativamente - ou, conforme Nitrini (2010, p.167) "o conceito de influência permite que se instrumentalize a ideia de modelo".

No que se refere à intertextualidade, há a referência a ideias anteriormente expostas de forma que haja uma reutilização de temas, onde o texto atual perfaz câmbios com o original, gerando assim, nas palavras de Perrone-Moisés (1990, p.94) "um vasto sistema de trocas, onde a questão da propriedade e originalidade se relativizam, e a questão da verdade se torna impertinente".

Ao dissertar sobre outras formas e possibilidades de trocas entre textos, PerroneMoisés (1990) apresenta ainda a visão proposta por Jorge Luis Borges, em que, de alguma forma, os escritores atuais, ao utilizarem referências anteriores, recriam os passados, funcionando como precursores daqueles. 
Jorge Luis Borges propõe uma total subversão do conceito de tradição, a partir de uma teoria da leitura. Em "Kafka e seus precursores", ele observa como uma obra forte nos obriga a uma releitura de todo o passado literário, onde passaremos a encontrar não as fontes daquele novo autor, mas obras que se tornam legíveis e interessantes porque existe esse autor moderno; obras que passam a ser, então, "precursoras" dessa nova obra. [...] Para Borges, portanto, a tradição é uma questão de leitura, de recepção, e como essa recepção se transforma em cada momento histórico, a tradição está constantemente sujeita a uma revisão, está em permanente mutação. (PERRONE-MOISÉS, 1990, p.95)

Considerando a visão de intertextualidade como esse sistema de trocas com outras disciplinas e questões culturais, e considerando a necessidade de se tratar de um tema específico no âmbito de uma obra literária - neste trabalho, o tema do sonho -, o estudo deve levar em consideração diferentes formas de leitura de seu conteúdo, em que tanto o texto em si como o seu entorno cultural sejam insumos para a análise.

Paralelamente, o estudo do tema [...] obriga o investigador a empreender duas leituras simultâneas dos textos analisados: em primeiro lugar, o texto é, no plano da criação literária, um universo coerente; em segundo lugar, a procura dum sentido deve ser feita no interior do texto e também no conjunto cultural a que esse texto pertence. Assim, passa-se obrigatoriamente duma análise formalista ou estruturalista do texto para uma análise intertextual e cultural: o texto literário é o lugar dialético onde se articulam estruturas textuais e extratextuais, participando o tema, justamente, das duas séries. (MACHADO; PAGEAUX, 2001, p.94)

Outro aspecto diz respeito aos estudos literários comparados no âmbito da América Latina. Conforme proposto por Pizarro (1985), seriam três possíveis formas de se analisar, de maneira comparada, a literatura latino-americana. A primeira, e a mais tradicional, seria aquela que enfatiza o eurocentrismo, relacionando obras ou autores da América Latina com outros da Europa Ocidental. A segunda seria efetuar comparações entre literaturas nacionais dentro da América Latina. E a terceira forma é a que permite apontar as heterogeneidades das literaturas nacionais em relação ao continente como um todo.

Neste trabalho, em que serão analisadas obras de escritores de Brasil e Argentina, naturalmente será considerada a segunda forma de comparação, mas levando em conta a necessidade de observar, nas semelhanças e diferenças de abordagens e intertextualidades, as identidades das obras e do espaço que constroem no âmbito da literatura universal.

la aproximación intertextual no podrá sino conducir a la observación de la riqueza del proceso, de la asimilación creadora de elementos [...]. La función del comparatismo en este caso tiene la doble posibilidad de ayudarnos, por una parte, a comprender procesos de identidad, y por otra a ubicarnos en el espacio que a nuestra literatura le corresponde en el ámbito de la literatura universal, a contribuir a construir el campo de lo que Étiemble llamó la literatura verdaderamente general. 
Así, al surgir, como una necesidad de la compleja configuración de nuestros sistemas literarios, se podrá transformar el signo de lo que ha sido su instrumentación en el Continente, para dar paso a un conocimiento real de nosotros mismos, así como de nuestras formas de relación con las literaturas del mundo. (PIZARRO, 1985, p.59)

A partir dos conceitos acima estabelecidos, ao analisar uma determinada obra podemos estabelecer possíveis relações da Literatura com diversas outras áreas do conhecimento humano. Ou conforme Steiner (2001, p.165), "nada há tão fascinante e tão conducente à hermenêutica que a experiência de observar e elucidar a intertextualidade da filosofia e da poética, de ouvir a música que habita o pensamento”.

\title{
1.2 Literatura e Filosofia
}

Esta inter-relação, certamente, não é exclusividade da Literatura: a própria Filosofia possui aproximações com diversos outros campos, sejam eles científicos ou não; pois "as ciências humanas aproximam a ciência do campo da Filosofia, o acolhimento filosófico da divergência e da subjetividade aproxima a Filosofia do campo da arte" (LYRA, 1984, p.14).

Esta ideia permite que, no âmbito da Filosofia, em função da necessária aceitação da divergência de pensamento, e considerando ainda o caráter subjetivo inerente a uma disciplina baseada em conceitos mentalmente construídos, seja possível a utilização de outros campos de estudo, como as artes e a ciência, outras formas distintas de pensamento.

\begin{abstract}
A filosofia quer salvar o infinito, dando-lhe consistência: ela traça um plano de imanência, que leva até o infinito acontecimentos ou conceitos consistentes, sob a ação de personagens conceituais. A ciência, ao contrário, renuncia ao infinito para ganhar a referência: ela traça um plano de coordenadas somente indefinidas, que define sempre estados de coisas, funções ou proposições referenciais, sob a ação de observadores parciais. A arte quer criar um finito que restitua o infinito: traça um plano de composição que carrega por sua vez monumentos ou sensações compostas, sob a ação de figuras estéticas. (DELEUZE; GUATTARI, 2004, p.253)
\end{abstract}

Especificamente no que se refere a este estudo, um dos tipos de arte, a Literatura surge como uma forma de saber que, a partir de diversas influências, é capaz de introduzir novos significados, especialmente pelo uso de uma linguagem que enseja a criação de imagens não diretamente perceptíveis, mas que possibilitam entendimentos diferentes e inovadores sobre determinado objeto.

Por se utilizar do discurso simbólico, metafórico, a Literatura seria então "uma das formas mais abrangentes do saber, porque se expressa através da palavra, como a Ciência e a 
Filosofia, embora descompromissada com a verdade empírica - conforme a Ciência Natural ou com a demonstração da verdade - conforme a Filosofia” (KHÉDE, 1984, p.34).

Importante ressaltar a necessidade de se evitar a subordinação da obra literária a conceitos filosóficos, como se a Literatura apenas reproduzisse, de forma artística, ideias anteriormente expostas no âmbito da Filosofia. Conforme exposto por Benedito Nunes, devese evitar estudar a obra literária como "a ilustração de verdades gerais", que seriam advindas da Filosofia. Mas deve-se permitir que a Filosofia opere como "uma aventura do pensamento diante da Literatura" e que a "dialogação com a obra literária [...] sempre colocará a imaginação nos limites do Entendimento" (NUNES, 1993, p.199).

Haveria, portanto, o risco de, ao se efetuar uma análise literária, reproduzir a ideia de que os conteúdos seriam necessariamente produzidos por teorias filosóficas e que aos escritores remanesceria o papel de criarem formas artísticas, cujas imagens permitiriam uma forma mais palatável de entendimento daquelas teorias, muitas vezes eivadas de uma linguagem hermética a grande parte dos leitores.

\begin{abstract}
Assim, só caberia aos escritores e aos poetas traduzir de maneira mais agradável aquilo que os filósofos já teriam pensado de maneira complicada ou "abstrata" [...]. No limite, isso significa que os filósofos sabem pensar, mas não conseguem comunicar seus pensamentos, que não sabem nem falar nem escrever bem; e que os escritores sabem falar bem, sabem se expressar, mas não têm nenhum pensamento próprio consistente. A imagem da literatura como sendo uma linguagem bela, mas vazia, que precisa de "recheio filosófico" para não se reduzir a uma brincadeira tão graciosa quanto fútil, tem seu oposto simétrico numa representação da filosofia como "pura" atividade intelectual, séria, profunda, complicada e incompreensível para o comum dos mortais. (GAGNEBIN, 2004, p.12)
\end{abstract}

Seria, portanto, uma espécie de estereótipo, em que o pensamento elaborado e complexo seria atribuição exclusiva de filósofos, tendo em vista que eles dominariam a capacidade de "pensar", mas sem a capacidade adequada para se expressarem. Aos escritores remanesceria a alternativa de produzir um discurso belo, mas de conteúdo vazio, sem que houvesse neste discurso qualquer possibilidade de produção de pensamento próprio; discurso que não passaria de uma espécie de "brincadeira" graciosa, mas fútil.

Desde que, na Grécia Antiga, Platão estabeleceu uma espécie de condenação dos poetas - e do trabalho ligado à mimese -, a separação entre Filosofia e Literatura tornou-se algo aparentemente irreconciliável, levando à construção de estereótipos como os acima apresentados. Conforme a ideia apresentada por Platão "o artista não mereceria um lugar na República por ser um imitador de nível inferior, alguém que poderia, inclusive, corromper a 
compreensão da juventude por lançar mão da ilusão como forma de representação" (MAGALHÃES, 2009, p.49).

O artista - ou o poeta - afastaria as pessoas do ideal, ao apresentar, em sua obra, representações da representação primeira, residente no mundo perceptível que vivemos. Enquanto ao filósofo estaria reservado o papel de afastar as pessoas das sombras em que permanecem, de conduzi-las ao plano das ideias, posto que presas ao universo material do mundo sensível.

$\mathrm{Na}$ idade Moderna, esta visão da obra poética, gradativamente, conduziu a uma exacerbação do pensamento racional, especialmente durante o período iluminista, que aprofundou a separação entre Filosofia e Literatura. No entanto, no final do século XVIII, o movimento romântico surgido na Alemanha irá se contrapor ao racionalismo, iniciando um processo de reaproximação entre ambas as disciplinas.

Conforme Martin Heidegger, a importância da linguagem poética estaria no revelar e ocultar o ser, ou seja, a representação na obra de arte de situações cotidianas das vidas em geral, a que todos estamos expostos, permite que o sujeito encare a sua própria situação particular de forma mais complexa e profunda.

\begin{abstract}
En lo existente y habitual nunca se puede leer la verdad. Más bien sólo acontece la apertura de lo manifiesto y el alumbramiento del ente cuando se proyecta la patencia y llega al estado de proyección. La verdad como alumbramiento y ocultación del ente acontece al poetizarse. Todo arte es como dejar acontecer el advenimiento de la verdad del ente en cuanto tal, y por lo mismo es en esencia Poesía. [...] La esencia poetizante del arte hace un lugar abierto en medio del ente, en cuya apertura es distinto que antes. En virtud de la proyección puesta en operación, la desocultación del ente que se proyecta hacia nosotros, todo lo habitual y lo hasta ahora existente deja de ser ente por virtud de la obra. (HEIDEGGER, 1992, p.110-111)
\end{abstract}

A partir da utilização da hermenêutica, Hans-Georg Gadamer sugere que, diferentemente do que se costumava considerar no âmbito da Filosofia, a verdade não é absoluta, mas sim vinculada à necessária compreensão do mundo ao redor e ao tempo vivido, uma percepção diferente daquela propugnada pelo racionalismo científico, em que somente seria verdadeiro aquilo que comprovado cientificamente, de forma definitiva.

Lo que me parece indiscutible es que la lengua poética tiene una relación peculiar, muy propia, con la verdad. Eso se muestra, en primer lugar, en que no se adecua en todo tiempo a cualquier contenido; pero también, en segundo, en que siempre que tal contenido adquiere la figura de palabra poética, experimenta una especie de legitimación. (GADAMER, 2013, p.111) 
No entanto, se eliminada esta restrição de cunho racionalista, que estabeleceu uma separação entre o elemento racional e o elemento sensível, poderíamos considerar que a Filosofia, na sua busca pela verdade, poderia se valer de outras disciplinas para construção do saber pretendido. Nesta busca torna-se fundamental "la revitalización de una dimensión simbólica del hombre que ha de estar a la misma altura que la dimensión racional, ya que sólo ambas, entrelazadas, dan cuenta de la complejidad de la naturaleza humana" (ARNÁIZ, 2013, p.50).

Por outro lado, o poeta, ao produzir sua obra literária, incorre num universo de novas possibilidades, situações imaginárias, ideias e sentimentos, cuja verdade não está estabelecida por regras racionais ou de caráter empírico. Na poesia, é possível a abordagem de questões científicas, históricas, sociais, culturais; sem que o poeta esteja preso a elas, pois o seu trabalho é direcionado pela busca da imagem, do elemento sensível, do mítico.

Assim, teríamos o filósofo buscando uma unidade absoluta do ser, na sua tentativa de encontrar a verdade, enquanto o poeta seria o responsável pelo trabalho de lidar com os fragmentos, com as coisas todas, individualmente, sem desprezo a nenhuma delas.

así como el filosofo si alcanzara la unidad del ser, sería una unidad absoluta, sin mezcla de multiplicidad alguna, la unidad lograda del poeta en el poema es siempre incompleta. [...] El filósofo quiere lo uno, porque lo quiere todo, hemos dicho. Y el poeta no quiere propiamente todo, porque teme que en este todo no esté en efecto cada una de las cosas y sus matices; o poeta quiere una, cada una de las cosas sin restricción, sin abstracción ni renuncia alguna. (ZAMBRANO, 2006, p.22)

Nesta vertente, a verdade não é um objetivo do trabalho poético, visto que é permeado pelo imaginário, pela criação de outra realidade; seja pela imitação, seja pelo mascaramento. A poesia seria então o espaço onde se torna possível o diálogo com outras áreas do conhecimento - ainda que discordantes - que provém de um "aceptar el mundo como ficción [...], de este mentir consciente, asumido y lúcido nace la persona, la máscara que oculta nuestra verdadera alma" (LÓPEZ, 2013, p.12).

Ainda no que se refere à relação entre Literatura e Filosofia, torna-se pertinente utilizar as assertivas propostas por Luigi Pareyson, que, em seu livro Os problemas da estética, afirma:

A filosofia pode estar presente como tal na obra literária e contribuir com esta sua explícita presença para o valor artístico da mesma. Naturalmente, há depois uma presença implícita, não menos eficaz e profunda, e é aquela pela qual tudo na obra, mesmo a mínima inflexão estilística, é significante, revela a espiritualidade do autor e, por isso, também o seu modo de pensar, a sua Weltanschauung, a sua filosofia. (PAREYSON, 1997, p.48) 
A presença da Filosofia na obra literária, portanto, não diminui seu valor artístico, e pode inclusive, com sua presença, contribuir na construção deste valor. No entanto, $a$ posteriori, esta presença remanesce como algo implícito, cuja importância será semelhante a todos os demais elementos, na construção da obra, na revelação do elemento artístico.

Considerando isto, podemos entender que Filosofia e Literatura podem conviver na obra literária, mas a obra literária tem em si a independência que possibilita a criação de algo que não está necessariamente vinculado aos conceitos que, originalmente, porventura a tenham influenciado.

No intuito de evitar incorrer na impropriedade de entender a Literatura como algo subordinado à Filosofia, neste trabalho se buscará apresentar diálogos plausíveis das obras analisadas com algumas ideias filosóficas, estabelecendo, sempre que possível, aproximações e divergências, de forma que a análise literária seja subsidiada por elementos não atrelados ou subordinados, mas que adjuntos permitam novos olhares e entendimentos sobre a obra estudada.

\subsection{Sonhos na Filosofia}

Sem pretender estabelecer uma relação exaustiva das abordagens existentes sobre a temática do sonho, este trabalho apresenta algumas referências que permitam a elaboração de uma análise comparada das obras de Cecília Meireles e de Jorge Luis Borges.

A abordagem dos sonhos na Filosofia remonta à Antiguidade, podemos verificar em Platão, na obra Teeteto, que, no diálogo estabelecido por Sócrates, surge o questionamento de como diferenciar a realidade no sonho e na vigília.

\footnotetext{
até podemos discutir se estamos acordados ou a sonhar e se o tempo em que estamos a dormir é igual àquele em que estamos acordados, e se em cada um destes a nossa alma sustenta sempre que as opiniões apresentadas são verdade acima de tudo; de modo que, metade do tempo, afirmamos que umas coisas são reais, na outra metade, que são as outras, mantendo ambas com a mesma firmeza. (PLATÃO, 2010, p.217)
}

Ainda na Grécia Antiga, a questão do sonho irá ser tratada também por Aristóteles, na obra Parva Naturalia, que aborda diversos aspectos relativos a fenômenos naturais, dentre eles, os períodos do sono e da vigília e o fenômeno do sonho; onde aspectos que discutem se os sonhos são pertencentes à alma ou ao corpo são tratados.

Ainda que a visão apresentada por Aristóteles seja fundada principalmente em questões de fundo biológico, há no texto discussão sobre a relação dos sonhos com a 
realidade, quando compara os sonhos aos reflexos na água, em que os movimentos corporais têm papel fundamental na formação das imagens, turbulentas ou claras, e no que se refere aos sonhos de predição do futuro, que o autor considera que não seriam de origem divina, diferentemente da percepção da época.

Posteriormente, no século XVII, René Descartes irá formular o chamado "argumento do sonho", em que considera que "o que podemos pensar que é real, poderia ser simplesmente sonhado" e que "não há indícios suficientes para estabelecer uma clara separação entre o real e o sonhado" (MORA, 2001, p.2737).

Descartes irá apresentar como argumentação o fato de que, muitas vezes, quando estamos sonhando, temos a percepção de que aquela situação é - ou parece ser - tão real, quanto a que vivemos durante o período da vigília. Em função disso, e de forma correlata, não teríamos como comprovar que, durante a vigília, poderíamos não estar vivendo algo semelhante ao que vivemos quando estamos sonhando.

\footnotetext{
Quantas vezes ocorreu-me sonhar, durante a noite, que estava neste lugar, que estava vestido, que estava junto ao fogo, embora estivesse inteiramente nu dentro de meu leito? Parece-me agora que não é com olhos adormecidos que contemplo este papel; que esta cabeça que eu mexo não está dormente; que é com desígnio e propósito deliberado que estendo esta mão e que a sinto: o que ocorre no sono não parece ser tão claro nem tão distinto quanto tudo isso.

Mas, pensando cuidadosamente nisso, lembro-me de ter sido muitas vezes enganado, quando dormia, por semelhantes ilusões. E, detendo-me neste pensamento, vejo tão manifestamente que não há quaisquer indícios concludentes, nem marcas assaz certas por onde se possa distinguir nitidamente a vigília do sono, que me sinto inteiramente pasmado: e meu pasmo é tal que é capaz de me persuadir de que estou dormindo. (DESCARTES, 1996, p.259)
}

O "argumento do sonho" será então fundamental para abordar a dualidade sono e vigília, e se a experiência do sonho poderia ser outra espécie de realidade perante a que vivemos quando estamos acordados.

Enquanto Descartes questiona a realidade ao confrontá-la com a experiência do sonho, George Berkeley irá elaborar a doutrina denominada "imaterialismo", na qual irá propor que a realidade está diretamente relacionada com a percepção, ou seja, somente existiria aquilo que é perceptível, e que, portanto, a existência seria algo exclusivamente realizado na mente.

Dar-se-á que a realidade das coisas sensíveis consiste no serem percepcionadas? Ou será ela qualquer coisa distinta do fato de serem percepcionadas, algo que não tenha relação com a mente? [...] Só falo a respeito das coisas sensíveis. E sobre essas, pergunto: por existência real das coisas sensíveis entendeis uma existência exterior à mente, e distinta do serem percepcionadas? (BERKELEY, 2005, p.99) 
A partir da discussão da realidade como algo necessariamente representado na mente, poderíamos, por analogia, considerar que o sonho - aparentemente, uma construção mental poderia representar uma espécie de outra construção de realidade, posto que perceptível.

Seguindo nesta discussão da realidade, Arthur Schopenhauer irá questionar como seria possível estabelecer uma forma de diferenciação entre sonho e a realidade vivida durante o período da vigília:

temos sonhos; não seria toda a vida um sonho? Ou, dito de maneira mais precisa: há um critério seguro para distinguir o sonho da realidade, os fantasmas dos objetos reais? A alegação de que o sonho possui vivacidade e clareza menores que a intuição efetiva não merece ser levada em conta, pois ninguém ainda teve os dois juntos um do outro para poder efetuar a comparação; mas se pode apenas comparar a lembrança do sonho com a realidade presente. (SCHOPENHAUER, 2013, p.18-19)

A partir destas questões, a realidade poderia ser pensada como uma construção do imaginário, tal como o sonho, mas também seria possível entender o sonho como outra forma de realidade, ou ainda que a realidade fosse uma espécie de sonho de outro plano ainda superveniente. Questões debatidas na Filosofia, e representadas na Literatura, como será visto na sequência.

\subsection{Sonhos na Literatura}

A temática do sonho na Literatura, nos moldes em que seria posteriormente utilizada em outras obras, teria se originado no Sonho de Cipião, capítulo VI da obra A República, de Marco Túlio Cícero, filósofo e político da Roma antiga. No capítulo citado, o personagem Cipião Emiliano conta seu encontro com o rei Massinissa, e o diálogo entabulado sobre seu avô Cipião, o Africano. Após a conversação, o personagem narra o sonho que teve após cair no sono.

No sonho, o personagem encontra seu avô, que lhe dá vários conselhos, com a recomendação de que não se esqueça do que lhe será dito. No decorrer do sonho se vê transportado para a Via Láctea, e, dentre outras assertivas, seu avô lhe diz que a vida na Terra é como a morte e que a vida depois desta é que seria a verdadeira.

Diversos elementos apresentados no Sonho de Cipião serão utilizados posteriormente em obras que tratam da temática do sonho, criando uma espécie de modelo para a construção do elemento onírico: 
maestro del que sueña; predicción del futuro político; descripción del cosmos y recriminación del maestro al soñador ante su insistencia en contemplar la tierra y no atender a la novedad que tiene ante sus ojos. (TRUEBA, 1999, p.92)

É a partir deste mundo novo possibilitado pelo sonho que diversas obras irão se pautar. A Literatura convive, normalmente, em diálogo com o imaginário, e, a partir do texto literário, se possibilita a criação mental de cenários e situações que são construídos pelo leitor durante o processo de leitura.

Durante a vigília, ainda que estejamos vinculados a uma realidade visível, no pensamento reside a possibilidade do devaneio, da elaboração de imagens não necessariamente relacionadas ao aparentemente concreto e perceptível.

No sonho, livre da amarra da consciência, o elemento imaginário ganha novas possibilidades, que permitem o surgimento de situações que poderiam ser aparentemente absurdas, ou mesmo impossíveis no mundo físico, mas que, no universo onírico, fomentam o surgimento de visões que talvez não fossem sequer imaginadas durante a vigília.

Segundo modelo proposto por Gilbert Durand, existiriam dois "regimes" de imaginário: um diurno, ligado ao período de vigília, em que a pessoa acordada, experimenta a possibilidade do devaneio; e outro noturno, subsistente durante o sono:

\begin{abstract}
No regime diurno do imaginário, as imagens expressam uma luta contra a passagem temporal e contra a morte que se afigura como um destino aterrorizante. Já no noturno, esse terror se eufemiza, expressando-se em duas modalidades estruturais: uma de "negação" do tempo, tentando ignorá-lo, mas, ao mesmo tempo, empreendendo a busca de um espaço livre da temporalidade; outra de aceitação ou inserção no tempo, vendo-se a repetição cíclica ou o fluir temporal como um eterno presente, cujas mudanças são formas de permanecer. (MELLO, 2002, p.10)
\end{abstract}

A partir desta dualidade, pode-se estabelecer a mesma relação entre sonho e devaneio, como espaços quase não interseccionais de criação de cenários imaginários distintos, vinculados a formas de expressão de diferentes intenções e possibilidades, em que a ação será pautada por questões temporais e de foro psicológico.

Seguindo neste apartamento de sonho e devaneio, Gaston Bachelard (2009, p.153) indica a "diferença radical" que ele considera existente entre ambos os eventos, diferença esta que residiria no "âmbito da fenomenologia", ou seja, na esfera dos estudos da consciência:

Ao passo que o sonhador de sonho noturno é uma sombra que perdeu o próprio eu, o sonhador de devaneio, se for um pouco filósofo, pode, no centro do seu eu sonhador, formular um cogito. Noutras palavras, o devaneio é uma atividade onírica na qual subsiste uma clareza de consciência. O sonhador de devaneio está presente no seu devaneio. Mesmo quando o devaneio dá a impressão de uma fuga para fora do real, para fora do tempo e do lugar, o sonhador do devaneio sabe que é ele que se ausenta 
- é ele, em carne e osso, que se torna um "espírito", um fantasma do passado ou da viagem. (BACHELARD, 2009, p.144)

A diferença, portanto, estará exatamente na "clareza de consciência" presente no devaneio e ausente no sonho, tendo em vista que no sonho noturno há a perda do "próprio eu". Seja como for, no âmbito do sonho - ou do devaneio - o imaginário poderá se estabelecer como espaço da possibilidade de criação de outros universos, não necessariamente reais. Sobre este universo onírico, interessante observar também a proposição de Maurice Blanchot:

o sonho é o despertar do interminável [...] daí resulta que o sonho parece fazer surgir, em cada um, o ser dos primeiros tempos - e não somente a criança mas, para além, para o mais longínquo, o mítico, o vazio e o vago do anterior. Aquele que sonha dorme, mas aquele que sonha já não é mais aquele que dorme, não é um outro, uma outra pessoa, é o pressentimento do outro, o que não pode mais dizer eu, o que não se reconhece em si nem em outrem. (BLANCHOT, 2011, p.293)

Blanchot reforça a ideia da perda da identidade do sonhador do sonho noturno, e indica que, numa espécie de viagem onírica, somos levados para lugares distantes, para longe do nosso "eu", na direção do universo do mito. Podemos considerar que a preponderância do elemento inconsciente no sonho faz com que surja algo que está apartado, que não é próximo, nem pessoal, nem mesmo reconhecível.

A liberdade contida no elemento imaginário existente no sonho faz com que, em várias obras literárias, haja relatos e narrativas onde o sonho seja recorrente, como forma de estabelecer um espaço onde a linguagem simbólica ali contida traga novas interpretações e perspectivas para os personagens. "Nesta direção, o símbolo afigura-se como o terreno eletivo do campo do imaginário, na medida em que é um meio através do qual o sentido pode manifestar-se e realizar-se" (MELLO, 2002, p.10).

O sonho pode ser percebido também como uma espécie de criação literária, considerando que nele são apresentados fatos - do cotidiano ou fantásticos -, em que há a possibilidade de participação de outras pessoas - ou personagens -; em todo remetendo a uma espécie de representação. Em uma série de entrevistas, o escritor argentino Jorge Luis Borges afirma que "o sonho é o mais antigo dos gêneros literários, [...] uma peça na qual somos o autor, o ator e o teatro. Ou seja, à noite, todos somos, de alguma maneira, dramaturgos.” (FERRARI, 2009a, p.154). 
Se o sonho traz diversas possibilidades de representação que surgem de forma inesperada, é no devaneio, que seria a capacidade de imaginar - ou sonhar - durante o período da vigília, que residiria o trabalho do poeta. Conforme Bachelard:

os documentos de onirismo desperto que o devaneio nos oferece devem ser trabalhados pelo poeta para receber a dignidade dos poemas. [...] A substância fluente dos nossos sonhos, os poetas nos ajudam a canalizá-la, a mantê-la num movimento que recebe leis. O poeta conserva muito distintamente a consciência de sonhar para dominar a tarefa de escrever o seu devaneio. (BACHELARD, 2009, p.153)

Considerando esta ideia, podemos entender o poeta como o responsável em propiciar que - a partir de seus devaneios - os leitores experimentem situações que os remetam ao universo onírico, e encontrem realidades e imagens que possibilitem reviver a experiência do sonho, às vezes desejada, especialmente quando confrontada com a realidade conhecida durante a vigília.

\subsection{Evolução da compreensão dos sonhos}

No âmbito da Filosofia, uma das disciplinas que guarda relação direta com a discussão sobre a realidade é a Metafísica, termo que, segundo MURCHO (2016, p.262), teria surgido a partir da obra de Aristóteles, assim nomeada por reunir textos que discutiam questões referentes não só à realidade, mas ao conhecimento, à lógica e à linguagem, ou seja, algo que vem depois da física. Uma definição para o termo seria que a Metafísica "é a disciplina que se ocupa dos problemas filosóficos mais gerais sobre a natureza da realidade" (MURCHO, 2016, p.259).

Normalmente, as ciências tendem a tratar seus objetos de estudo de forma limitada ao próprio ente estudado, desconsiderando todo o mais que o circunda, ou considerando que todo o mais não passaria de nada. Cada ciência tem o seu foco, e cada uma explica completamente um determinado ente de acordo com suas leis e teorias. A questão é que disciplina se ocuparia de todo o resto, de todo o nada restante?

Frente a eso, la ciencia tiene que volver a afirmar ahora su seriedad y lucidez: que lo único que le importa es lo ente. ¿Qué otra cosa le puede parecer a la ciencia la nada más que un espanto y una fantasmagoría? Si la ciencia está en lo cierto, entonces una cosa es segura: la ciencia no quiere saber nada de la nada. [...] Al meditar sobre nuestra actual existencia, en cuanto está determinada por la ciencia, nos vemos inmersos en un conflicto en el que se ha desarrollado ya un preguntar. Lo único que exige la pregunta es ser expresada con propiedad: ¿qué pasa con la nada? (HEIDEGGER, 2003, p.18) 
Diferentemente da ciência, cuja visão é fragmentada, a Metafísica se preocupa com a realidade como um todo, e com a natureza filosófica dessa realidade. Dessa maneira, conforme MURCHO (2016, p.260) "os problemas do livre arbítrio e da identidade pessoal, [...] a natureza e existência de divindades são problemas metafísicos”. Portanto, temas afeitos à Religião, como a existência ou não de Deus, são de ordem metafísica, não por serem místicos ou sobrenaturais, mas por se referirem a problemas filosóficos relacionados à realidade.

Durante longo período da história, questões de ordem religiosa e/ou metafísica predominaram no pensamento ocidental, fazendo com que as explicações da realidade passassem por argumentos desprovidos de rigor científico. A percepção dos sonhos como de origem divina, ou seu caráter premonitório, são exemplos desta situação. Somente a partir da Idade Moderna, com a ênfase no racionalismo e no conhecimento científico, o saber filosófico retomará importância na civilização ocidental.

\begin{abstract}
Porque hemos visto que Platón, que despreció a la poesía, que erigió en un imperio más alto que nadie a la razón, iba cargado por un designio más generoso y universal, más verdaderamente amante de la unidad, que lo que a primera vista encontramos en su condenación de la poesía. Por eso no le bastó la filosofía y tuvo que hacer teología y tuvo que descubrir, fortaleciéndola, fundamentándola y aclarándola, la mística. Pero, no todos los filósofos han procedido llevados de iguales ansias. Mucho más tarde, en la vida de esa parte del mundo llamada Europa, y en el momento histórico llamado Época Moderna, la Filosofía volvió a nacer por segunda vez, renació y con ello sus pretensiones imperiales fueron presentadas de nuevo, pero de diferente manera. Porque la primera esperanza había quedado fundada. La Edad Media y el Renacimiento han recogido esta herencia platónico cristiana, y era tal su firmeza, que hasta dentro del ascetismo se había hecho lugar para el goce. (ZAMBRANO, 2006, p.73-74)
\end{abstract}

A ênfase na racionalidade e no conhecimento científico na época moderna, naturalmente, fizeram com que assuntos de ordem metafísica perdessem a importância que até então possuíam na sociedade, ainda que temas dessa ordem nunca tenham sido completamente abandonados no âmbito do pensamento filosófico e das artes em geral.

Conforme MELLO (2009, p.12), no final do século XVIII, "os filósofos românticos alemães [...] vão recuperar o elo entre a criação poética e a filosofia, sobretudo neoplatônica, como também os diálogos com o pensamento hermético dos alquimistas". Além disso, posteriormente, no século XIX, movimentos literários, como Romantismo e Simbolismo também irão utilizar temas de ordem metafísica.

Nesta tentativa de explicar a realidade, a partir de uma visão metafísica, questões e mitos religiosos serão frequentemente utilizados em obras literárias. Dentro deste espectro, as 
religiões e o pensamento oriental, especialmente os de origem hindu e budista, serão fonte para novas percepções da forma como está estabelecido o mundo real que conhecemos.

$\mathrm{Na}$ visão indiana do Samkhya, o espírito - ou purușa - é uma consciência pura fora do tempo que testemunha os acontecimentos do presente, conservando uma identidade que não se modifica com a realidade vivida, "la conciencia no es una facultad que puedan ejercer o no los seres, sino una realidad metafísica que trasciende el espacio y el tiempo, que se encuentra más allá de toda contingencia y de toda transformación” (ARNAU, 2012, p.91).

$\mathrm{Na}$ visão budista, uma mesma realidade pode ser aproximada por três percepções distintas: cósmica, humana ou a partir do ente ou objeto; conforme aquele que observa.

\begin{abstract}
Ese algo (lo real), cuando se contempla desde la perspectiva cósmica se denomina brahman, mientras que si se hace desde la conciencia individual se denomina atman. [...] Además, las visiones cósmicas y psicológicas no agotan la diversidad de lo real, a este enfoque dual hay que añadir una tercera perspectiva que tiene en cuenta el punto de vista de los propios objetos. Encontramos así una terna de aproximaciones diferentes (cósmica, humana y entitiva) a una misma realidad. [...] No hay tampoco una predominancia de lo metafórico sobre lo literal, o a la inversa. La mente no es una metáfora del cosmos y el cosmos no es una metáfora de la mente. Ambos son igualmente literales y metafóricos. (ARNAU, 2012, p.128)
\end{abstract}

As diferentes formas de perceber a realidade e sua natureza, seja ela física ou psíquica, são importantes para compreender a percepção do fenômeno do sonho. No decorrer da História, a relação das sociedades com os sonhos passou por modificações decorrentes de abordagens e interpretações religiosas, filosóficas ou científicas. A variação no tratamento do tema no decorrer do tempo e a forma com que se opera permitem abrir a possibilidade de se compreender como se expressava a mentalidade da sociedade no período estudado.

\footnotetext{
Os sonhos são transformados em material histórico. Sonhos de vitória ou de derrota, premonitórios de sucessos ou de desgraças pessoais, sonhos oraculares e enigmáticos decifrados à luz de eventos subsequentes são registrados por cronistas, historiadores e biógrafos. De fato, e de maneira quase paradoxal, o recurso a sonhos relevantes reforça e subscreve a autenticidade do evento histórico. (STEINER, 2001, p.214-215)
}

A partir de uma visão histórica, pode-se perceber o sonho como uma forma de registro de um tempo e de seus eventos, mas também, a partir da observação dos relatos, entender a maneira como as pessoas compreendiam o sonho e de que modo esta experiência as ajudava a entender a realidade em que viviam, além das questões existenciais perante esta realidade.

Desde a Antiguidade, a referência aos sonhos na cultura ocidental esteve presente, normalmente apresentando o caráter coletivo sobreposto ao individual ou íntimo. O sonho 
muitas vezes era considerado como uma espécie de conexão com o elemento divino, possibilitando o recebimento de revelações, que funcionariam como profecias para a coletividade.

No mundo ocidental, uma das vertentes fundamentais para a consideração do tema é aquela originada da cultura grega antiga. Além dos anteriormente citados Platão e Aristóteles, há que se fazer referência a Homero, em cujas obras, Ilíada e Odisseia, o sonho se faz presente.

Na Ilíada, é por intermédio de um sonho enviado por uma divindade, Zeus, que Agamenon resolve reunir as tropas para retomar o ataque à Tróia. Na Odisseia, há referência às "portas do sonho", símbolo também citado na Eneida de Virgílio, na passagem em que Ulisses (ou Odisseu) disfarçado de mendigo conversa com sua esposa Penélope sobre um sonho preditivo:

Penélope, após relatar seu sonho a Odisseu, fala que os sonhos, ambíguos, nem todos se realizam. Há duas portas de sonhos pelas quais eles passam, diz ela: a de chifre e a de marfim. Os que saem pela porta de chifre se realizam; os da porta de marfim são enganosos. (MENESES, 2002, p.27)

Nos dois episódios citados, pode-se perceber características da forma como o sonho era percebido na cultura grega antiga: um espaço propício ao contato com o componente divino, em que é possível o recebimento de mensagens ou revelações que permitem ao sonhador realizar previsões sobre o futuro seu ou da coletividade.

Fundamental na formação da cultura ocidental, a religião cristã também apresenta referências aos sonhos em seus textos sagrados. Tanto no chamado Antigo Testamento recebido da cultura judaica - como no Novo Testamento há na Bíblia diversas passagens em que são apresentadas narrativas de sonhos, em que também está presente o caráter premonitório e a possibilidade de contato com seres divinos ou sobrenaturais.

Esta tradição dos sonhos vinda da Antiguidade não só será mantida, como será diversificada no cristianismo durante a Idade Média, fazendo com que os sonhos premonitórios, ou visões, experimentados por religiosos e nobres passem a ser especialmente considerados para os rumos da sociedade da época.

A la cristiandad le fue legada esta tradición por medio de la Biblia que, como es sabido, contiene una serie de sueños, tales como el de Daniel o el de Jacobo; del mismo modo, encontramos en el Nuevo Testamento experiencias oníricas tales como aquélla que revela el nacimiento de Jesús o la de José, en la cual el ángel lo insta a huir. Ya desde la temprana Edad media cristiana el abanico de experiencias oníricas conocidas era amplio, siendo sus depositarios personajes notables, tales 
como santos, frailes y clérigos, reyes y príncipes. Las conversiones motivadas por un sueño eran, por otra parte, numerosas. Aunque la Antigüedad clásica conocía, como queda dicho, la dimensión individual del sueño, el cristianismo le dio un empuje pues, al aceptar que el creyente pudiera recibir mensajes celestes (o demoníacos) mientras dormía, hizo del sueño un espacio de encuentro virtual e inmediato entre el creyente y Dios (o el Diablo). (ROSE; SCHMIDT; WEBER, 2011, p.16)

Nos séculos subsequentes, consolidou-se no continente europeu aquilo a que se convencionou considerar como "cultura ocidental", que, apesar das diversas diferenças regionais, reúne em sua essência, primordialmente, elementos tanto da cultura grega como do cristianismo.

\subsection{A tradição dos sonhos na literatura ibérica}

A chamada Península Ibérica, região que hoje abriga os países Portugal e Espanha, esteve, durante a Idade Média, parcialmente dominada pelos árabes. Em que pese as influências recebidas neste período, a região manteve uma cultura mais próxima dos demais países europeus, ainda que com características regionais muito particulares. Após o invento da imprensa, e a consequente ampliação da capacidade de disseminação da informação, tornouse viável o desenvolvimento das literaturas nacionais em vários países europeus.

Especificamente na Península Ibérica, ocorrerá o aparecimento de muitas obras, algumas fundamentais na consolidação dos idiomas e das culturas nacionais dos países da região. Após o descobrimento da América, Espanha e Portugal viveram um período de opulência, especialmente em função da exploração das colônias instaladas no novo continente.

Em termos culturais, nas artes em geral, a Espanha viverá aquilo que se denominou o Siglo de Oro, que compreenderá todo o século XVI e grande parte do século XVII, num período artístico que abrange o Renascimento e o Barroco. Período em que o tema do sonho foi tratado também por vários escritores.

Neste período, foi publicada aquela que é considerada por muitos como a principal obra da Literatura Espanhola em todos os tempos: El ingenioso hidalgo don Quijote de la Mancha. Ainda que não seja tema específico da obra, há pelo menos dois trechos em que os personagens relatam situações que remetem ao universo onírico.

A primeira referência ocorre no capítulo XXIII da segunda parte, quando o personagem principal, Don Quijote, visita a cueva de Montesinos, e adormece no local. Posteriormente, quando reencontra seus companheiros que ficaram fora da gruta e lhes conta 
tudo que há sucedido nos subterrâneos, é informado ter ficado apenas uma hora no local, enquanto crê ter passado três dias no interior da gruta.

A outra referência ocorre no capítulo XLI, também da segunda parte, quando os personagens são colocados em um cavalo de madeira de nome Clavileño e, com os olhos vendados, são convencidos de que estão voando. Após o suposto retorno ao solo, o personagem Sancho Panza, conta diversas visões que teria tido do alto, todas fantasiosas; uma autêntica criação literária surgida do devaneio do escudeiro.

sabemos que uno y otro solamente pudieron ver lo que cuentan en sueños, como les ocurre a los personajes de tantas otras obras literarias que tanto Cervantes como el lector conocen bien. A través de los sueños de Don Quijote y Sancho hacemos los lectores un viaje al otro mundo, pero no a un más allá ultraterreno, sino al mundo literario de los libros de caballerías. (TRUEBA, 1999, p.289)

Podemos perceber que a ficção surge a partir dos sonhos e devaneios dos personagens, uma ficção que remete ao universo dos livros de cavalarias, retratados de forma irônica na obra. Se as referências ao sonho na obra de Miguel de Cervantes são episódicas, em outras obras do Siglo de Oro, o sonho tem papel protagonista.

Um dos escritores mais reconhecidos do período, Francisco de Quevedo publicou no século XVII uma das obras mais importantes do Barroco espanhol: Sueños y discursos de verdades descubridoras de abusos, vicios y engaños en todos los oficios y estados del mundo.

Os Sueños de Quevedo estão divididos em cinco partes denominadas: Sueño del Juicio Final, El alguacil endemoniado, Sueño del Infierno, El mundo por de dentro y Sueño de la muerte. No entanto, conforme TRUEBA (1999), somente as partes Sueño del Juicio Final e Sueño de la muerte seriam, de fato, representações de sonhos noturnos, enquanto o Sueño del Infierno seria melhor classificado como uma visão, em função de não haver referência ao ato de dormir, nem de acordar.

Segundo TRUEBA (1999), a obra Sueños pode ser considerada como um exemplo do gênero conhecido por sátira menipeia, gênero que, de acordo com a classificação proposta por Mikhail Bakhtin, possui diversas características, dentre as quais:

La menipea [...] no se ajusta a ninguna exigencia de la verosimilitud externa, se destaca por una excepcional libertad de la invención temática y filosófica [...] la fantasía más audaz e irrefrenable y la aventura se motivan, se justifican y se consagran interiormente por el propósito netamente filosófico de crear situaciones excepcionales para provocar y poner a prueba la idea filosófica. [...]

En la menipea también aparece por primera vez aquello que podría llamarse experimentación psicológico-moral [...]

Sueños, visiones y locura destruyen la integridad épica y trágica del hombre y su destino: manifiestan las posibilidades de otro hombre y de otro destino en la persona 
que pierde su carácter concluso y simple y deja de coincidir consigo misma. Los sueños nocturnos son habituales en la epopeya, pero aparecen como profecía, impulsan una acción o sirven como premonición y no hacen salir al hombre fuera de su destino y carácter, no destruyen su integridad.

Desde luego, en la menipea este carácter inconcluso del hombre y esta su no coincidencia consigo mismo son aún elementales e incipientes, pero ya están descubiertos y permiten una nueva visión del hombre. La actitud dialógica para uno mismo (que se aproxima al desdoblamiento de la personalidad), en la menipea contribuye también a la destrucción de la integridad y cerrazón del hombre. (BAJTÍN, 2003, p.167-170)

Verificam-se, então, alguns pontos importantes que podem indicar uma forma de como o tema do sonho veio a ser tratado em obras posteriores: a liberdade temática e filosófica; a ficção orientada por um propósito filosófico; e o desdobramento da personalidade do homem apartado do seu destino.

Outra obra a ser considerada dentro da temática do sonho, que também pertence ao período do Siglo de Oro da literatura espanhola, apesar de ter sido escrita no continente americano, é Primero sueño de Sor Juana Inés de la Cruz, escritora nascida no atual México.

A obra poética Primero sueño apresenta a experiência da alma durante um sonho noturno. Enquanto o corpo dorme, durante o sonho, os órgãos vitais do corpo acompanham a alma em sua jornada de encontro com a liberdade e a busca pela sabedoria. Nesta obra, segundo KOHUT (2011, p.159), Sor Juana utiliza os instrumentos possibilitados pela Literatura, como metáforas e símbolos, para expressar os conteúdos filosóficos que deseja expor.

Finalmente, em relação ao Siglo de Oro, não se pode olvidar Pedro Calderón de la Barca, escritor notabilizado principalmente pelas peças teatrais, dentre as quais está aquela que é considerada sua principal obra, e que também trata da temática do sonho: La vida es sueño.

Marcada pela visão proposta pelo estoicismo - doutrina que prega a busca por uma existência sem apegos materiais e voltada para o exercício da virtude -, a obra teatral La vida es sueño apresenta como protagonista o príncipe Segismundo, filho do rei da Polônia.

Em razão de uma profecia, o príncipe passa sua vida encarcerado até o momento em que lhe é dada a possibilidade de reinar por um dia, para posteriormente ser devolvido ao cárcere, de forma que o ocorrido lhe pareça ter sido apenas um sonho.

A referência à vida como uma espécie de sonho, relativizando a realidade, se adequa à argumentação estoica de que o indivíduo deve pautar suas ações pela virtude e evitar conduzir sua existência de forma desregrada, atendendo de forma desmedida aos prazeres. Uma cena importante da obra que apresenta alguns desses elementos é o trecho conhecido como 
Solilóquio de Segismundo, em que o protagonista apresenta algumas das suas inquietudes em relação à vida.

\author{
Es verdad, pues: reprimamos \\ esta fiera condición, \\ esta furia, esta ambición, \\ por si alguna vez soñamos. \\ Y sí haremos, pues estamos \\ en mundo tan singular, \\ que el vivir sólo es soñar; \\ y la experiencia me enseña, \\ que el hombre que vive, sueña \\ lo que es, hasta despertar.
}

Sueña el rey que es rey, y vive con este engaño mandando, disponiendo y gobernando; y este aplauso, que recibe prestado, en el viento escribe y en cenizas le convierte la muerte (¡desdicha fuerte!): ique hay quien intente reinar viendo que ha de despertar en el sueño de la muerte!
Sueña el rico en su riqueza, que más cuidados le ofrece; sueña el pobre que padece su miseria y su pobreza; sueña el que a medrar empieza, sueña el que afana y pretende, sueña el que agravia y ofende, y en el mundo, en conclusión, todos sueñan lo que son, aunque ninguno lo entiende.

Yo sueño que estoy aquí, destas prisiones cargado; y soñé que en otro estado más lisonjero me vi. ¿Qué es la vida? Un frenesí. ¿Qué es la vida? Una ilusión, una sombra, una ficción, y el mayor bien es pequeño; que toda la vida es sueño, y los sueños, sueños son.

(DE LA BARCA, 1822, p.21)

Verifica-se no Solilóquio de Segismundo, a presença da visão estoica na postura do protagonista perante a vida, ao relativizar a realeza, a riqueza e mesmo a pobreza. Uma atitude que o leva a considerar que "el hombre que vive, sueña lo que es", e assim, a própria vida não passaria de "un frenesí" ou "uma ilusión". A conclusão a que chega é a de que a vida 
é um sonho, uma perspectiva da realidade, e das ilusões dela decorrentes, que está em conformidade com características do Barroco, estilo dominante no século XVII.

\begin{abstract}
Uno de los fenómenos más característicos del Barroco, resultado - entre otros, - de la adversa coyuntura histórica, es la depreciación de la realidad. Las alusiones a la vida como sueño, como algo fugaz e inconsistente son una constante barroca. La duda entre lo ilusorio y lo real preocupa a todos los pensadores de la época y le permitirá a Descartes poner las bases de la filosofía moderna. Ya en el siglo XVI, ascetas y místicos no dejan de advertir sobre la apariencia engañosa de las cosas y de comparar la vida terrena del hombre a una breve representación teatral o a un sueño. Varios dramaturgos, [...] sobre todo en primera mitad del siglo barroco, se preocupan de la problemática del sueño y hacen de él un motivo o hasta un tema de sus obras. (SABIK, 1998, p.109)
\end{abstract}

O estilo literário presente nas obras do período Barroco, normalmente caracterizado pela oposição de conceitos, pelo espelhamento, se mostra aderente à visão da realidade como sonho, ou pelo menos, como uma visão questionadora do real, tal qual a proposição de Descartes, anteriormente observada no seu "argumento do sonho". A partir do teatro de Calderón estas conjecturas se estabelecem de forma categórica no imaginário e na cultura espanhola, e, consequentemente, na cultura ibérica.

Em Portugal, no século XVI, é publicada a obra fundamental para a literatura lusitana: Os Lusíadas, de Luís Vaz de Camões. Narrada em versos, em forma de epopeia, a obra relata episódios da história portuguesa, em especial aqueles referentes ao navegador Vasco da Gama durante sua viagem de descobrimento do caminho marítimo para a Índia.

No Canto IV, há o relato de um sonho que acomete o rei Dom Manuel, onde aparecem, na forma alegórica de dois anciãos, os rios Ganges e Indos, e que, em tom profético, aconselham o rei a empreender as navegações para a Índia. É a retomada do sonho como elemento premonitório, visto desde a Antiguidade.

Sobre esta condição do sonho premonitório, vimos que é uma característica que estava presente tanto na cultura grega - e na sua mitologia -, como na tradição cristã. Em $O s$ Lusíadas há referência a ambos os elementos, fazendo com que o texto apresente uma integração semelhante àquela existente na própria cultura ocidental. Sobre este aspecto na obra de Camões, e considerando ainda a ideia do sonho como criador de ficção, Borges comentou:

a memória de Camões estava cheia de mitologia, os seus dias e as suas noites estavam cheios de Homero e de Virgílio e essa mitologia estava entrelaçada nele, é uma característica própria de um homem do Renascimento [...] o fato de que nessa epopeia cristã os deuses intervenham com tanta frequência, [...], não se trata simplesmente de que Camões tenha pensado que na Eneida e na Odisseia e na Ilíada 
os deuses intervinham nos assuntos do homem mas que sentia esses deuses. Neste caso, [...] para Camões, que não vivia menos nos episódios quotidianos da vida do que na sua imaginação, os deuses eram reais, de tal maneira que Baco pode disfarçar-se em Moçambique ou pode tentar enganar os portugueses e que Vênus e Marte podem ajudá-los e isto não eram incongruências para ele que vivia no mundo, digamos, da mitologia cristã e da mitologia pagã, e é verdade que a sua vida foi uma vida de sonhos e de imaginações, e que sem esses sonhos e essas imaginações ele não teria podido escrever Os Lusíadas durante os longos anos adversos e as longas navegações. (BORGES, 2001, p.34-35)

A convivência das mitologias no escritor, na sua cultura e no mundo em que vive, propiciam o surgimento do sonho e da imaginação, e a partir desses elementos a ficção nasce. Sem o sonho, a ficção não seria possível; sem a ficção, a realidade não se sustenta.

Durante o século XVII, outro escritor que tratou do elemento do sonho foi o Padre Antônio Vieira, autor de cartas, profecias e, principalmente, sermões que têm relevância no período do Barroco lusitano e brasileiro, tendo em vista ter vivido durante muitos anos na América portuguesa.

Vieira escreveu três sermões sobre sonhos de São Francisco Xavier, nos quais, ao tratar do trabalho de missionário do santo, busca elaborar uma espécie de síntese de diversos autores, na tentativa de estabelecer a explicação dos sonhos.

\footnotetext{
En estos sermones, Vieira buscó lograr una síntesis entre lo que decían Aristóteles, Galeno, San Agustín, la Biblia y las epopeyas sobre los sueños y lo que sostenía la oniromancia vigente en Portugal, en el mundo ibérico y católico, sobre el funcionamiento y el origen de los sueños naturales, divinos y diabólicos. (LIMA, 2011, p.344)
}

No prefácio da obra, o Padre Vieira apresenta sua visão sobre o que seriam os sonhos: "são uma pintura muda, em que a imaginação a portas fechadas, e, às escuras, retrata a vida e a alma de cada um, com as cores das suas ações, dos seus propósitos e dos seus desejos" (VIEIRA, 1694, p.6).

No primeiro dos três sermões sobre sonhos da obra Xavier Dormindo e Xavier Acordado, há o relato de uma luta travada entre São Francisco Xavier e um índio gigante, que, conforme o Padre Vieira relata, seria uma profecia da luta do santo pela conversão da Ásia: "não há dúvida que tudo isto foram profecias do muito que o Santo havia de cansar e trabalhar na conversão daquele grande gigante da Ásia, e vastíssimo Império do Oriente" (VIEIRA, 1694, p.4).

No segundo sermão, Vieira relata o sonho que o santo teve num hospital na cidade de Roma, que o fez acordar aos gritos. No sonho, Deus revela os sofrimentos pelos quais São 
Francisco Xavier ainda passaria em vida, dando ao sonho o caráter profético, a partir da revelação divina.

No terceiro sermão, o último constante da primeira parte do livro denominada Xavier Dormindo, o santo se encontra com o demônio em sonho, e apesar das tentações a que é submetido, vence as tentações e, consequentemente, o próprio demônio, conforme o relato de Vieira.

No livro, o Padre Vieira apresenta, ainda, sua percepção relativa ao processo de formação do sonho, em que afirma existirem sonhos naturais e sonhos sobrenaturais, que seriam também divinos. Acrescenta ainda que os sonhos divinos possuem como característica a ordem, como forma de permitir que se entenda o significado que contêm:

\begin{abstract}
Um dos maiores mistérios e mais delicados segredos da natureza na arquitetura humana é a fábrica dos sonhos. Sendo o sono uma prisão universal dos sentidos, com que os olhos não vêem, nem os ouvidos ouvem [...]; como pode ser que sonhando, vemos sem ver, e ouvimos sem ouvir [...]? A razão, ou filosofia deste artifício natural é porque na memória (não a espiritual, que é potência da Alma, senão a corporal e sensitiva) estão depositadas as espécies de todos os objetos, ou as imagens de todas as coisas que entram pelos sentidos. Estas imagens, enquanto os sentidos dormem, estão encobertas, e escondidas debaixo dos vapores grossos e espessos que sobem ao cérebro. [...] Porque as imagens escondidas das coisas que entraram pelos sentidos, desafogadas dos vapores que as oprimiam, se vão descobrindo, e aparecendo à fantasia, ou sem nenhuma ordem, se os sonhos são naturais; ou se são sobrenaturais e divinos, com aquela ordem e disposição que é necessária para mostrarem e darem a entender o que significam. (VIEIRA, 1694, p.47-48)
\end{abstract}

Em Portugal, importante também pontuar a existência de um movimento de caráter messiânico, denominado Sebastianismo, surgido no final do século XVI, com o desaparecimento de D. Sebastião - herdeiro do trono português - ocorrido em uma batalha no norte do continente africano. A partir deste evento, a nação portuguesa passou a conviver com a expectativa do retorno do nobre como forma de salvação, um período em que os sonhos proféticos passaram a ter papel decisivo para a manutenção do estado português.

As obras literárias citadas permitem observar a marcante presença do elemento onírico nas culturas de Portugal e Espanha, durante o período da conquista do continente americano. Com o processo de colonização, tradições culturais desses países ibéricos foram naturalmente levadas para os novos territórios, onde viriam a surgir novos países, como o Brasil e a Argentina, dos escritores Cecília Meireles e Jorge Luis Borges. 


\subsection{Os sonhos no século XX}

Especificamente na primeira metade do século XX, a ênfase do tema do sonho pode ser atribuída à publicação, em 1900, do livro A Interpretação dos Sonhos de Sigmund Freud. Em que pese as críticas à obra em si ou ao não ineditismo do assunto, o livro obteve grande popularidade e detém ainda hoje grande importância na área da Psicologia.

Em contraposição à percepção dos sonhos como algo de natureza divina ou profética, conforme Costa (2006, p.5), Freud propôs que os sonhos seriam resultado de um processo primário de desejos do inconsciente e que a aparência absurda que por vezes apresentam seria resultado de um processo secundário de censura: “o sonho é uma realização (disfarçada) de um desejo (suprimido ou recalcado)" (FREUD, 2001, p.115).

Ao indicar uma abordagem científica para interpretar sonhos e atribuir ao inconsciente um caráter atemporal, Freud quebrou a tradição de ver mensagens proféticas nos sonhos, mudando o foco dos fatos hipotéticos do futuro para desejos da infância do sonhador guardados no inconsciente.

Nos anos seguintes, a Psicologia viria a se consolidar como uma ciência independente, e o tema do sonho seria tratado por outros teóricos da área, dentre os quais Carl Gustav Jung. Diferentemente das proposições de Freud, Jung considerava que os sonhos não representariam apenas questões íntimas do passado, mas também aspectos culturais do indivíduo. Nesta concepção, os mitos seriam responsáveis pela ligação entre o consciente e o inconsciente.

Os trabalhos na área da Psicologia, especialmente no âmbito da Psicanálise, influenciaram diversos movimentos artísticos de vanguarda surgidos na primeira metade do século XX, como o Expressionismo - em que a realidade decorria da exposição dos sentimentos mais íntimos -, e do Surrealismo, em que o elemento do sonho teve papel preponderante, conforme pode ser percebido neste trecho do Manifesto do Surrealismo de André Breton - publicado em 1924 - em que estabelece comparações entre sonho e realidade:

meu sonho da última noite talvez continue o da noite precedente e seja continuado pelo da próxima noite, com um rigor meritório. [...] E como não está absolutamente provado que, assim sendo, a realidade que me ocupa subsiste em estado de sonho, que ela não desaparece no imemorial, por que não concederia eu ao sonho o que, às vezes, recuso à realidade, seja este valor de certeza em si mesma que, a seu tempo, não se expôs a minha negação? Por que não haveria eu de esperar do indício do sonho mais do que espero de um grau de consciência cada dia mais elevado? $\mathrm{O}$ sonho não pode ser ele também aplicado à solução das questões fundamentais da vida? (BRETON, 2002, p.181) 
Importante citar ainda no século XX, o trabalho de Jacques Lacan, que, segundo Costa (2006, p.16) entenderia o sonho como responsável pelo encontro da realidade com a realidade psíquica, construída a partir da representação advinda da linguagem, que é inescapável aos seres humanos, e que os afasta da natureza.

Em conferência realizada um ano antes de sua morte, denominada Religião e Poesia, Cecília Meireles cita diretamente o Surrealismo como um movimento em que a valorização do elemento inconsciente é fundamental, além de fazer referência ao fato de que não se estava indiferente ao trabalho de Freud:

Depois do simbolismo, [...] talvez a escola poética mais próxima, em sua essência, do sentimento místico do mundo, que não foi indiferente à cogitação metafísica [...], uma das mais interessantes tentativas de expressão poética é a do "surrealismo", se quisermos usar a palavra mais próxima da escola do poeta francês André Breton [...], que vem valorizar o inconsciente. Devíamos não intervir intelectualmente: deixar que a comunicação poética se fizesse espontânea, ainda que incoerente, como uma fonte que se desata da sombra. Freud não esteve ausente nessa nova inquietação. Talvez os mundos submersos em nós sejam a nossa verdade profunda, e talvez neles nos encontremos explicados e compreendidos. (MEIRELES, 1963, apud GOUVÊA, 2008, p.214) ${ }^{1}$

Em uma entrevista a Emir Rodriguez Monegal, Borges expressou sua aversão à obra de Freud, contrapondo que teria lido muito Jung, o que, conforme Bernucci (2001, p.79), seria uma forma de encontrar "em Jung uma autoridade de peso que estivesse à altura daquele problemático doutor Freud, cujas teorias, certamente, incomodaram o escritor”. Em relação a André Breton, Borges fez críticas de cunho político em um artigo de 1938, denominado Un caudaloso manifiesto de Breton.

Seja como for, ambos os escritores certamente não estiveram imunes a toda turbulência provocada pelas novas ideias trazidas pela Psicologia, especialmente no que se refere ao estudos do inconsciente. Ainda que estas questões não sejam utilizadas neste trabalho para efeito de análise das obras, certamente contribuíram para que o tema do sonho tenha tido relevância na primeira metade do século XX.

\footnotetext{
${ }^{1}$ MEIRELES, Cecília. Conferência pronunciada em 1963 na Associação Brasileira de Imprensa.
} 


\section{CAPÍTULO 2}

\section{CECÍLIA MEIRELES E OS SONHOS}

Em ensaio publicado numa coletânea de textos apresentados no Seminário Internacional Cecília Meireles, realizado na Universidade de São Paulo em 2001 - ano do centenário da poeta - Alfredo Bosi cita que "perguntada sobre qual seria o seu maior defeito, ela respondeu: "uma certa ausência do mundo"” (BOSI, 2007, p.13).

\subsection{Vida e obra}

Cecília Meireles nasceu em 1901, na cidade do Rio de Janeiro, então capital do Brasil. Desde cedo, a poeta acostumou-se a enfrentar uma realidade de dificuldades, seu pai morreu três meses antes de seu nascimento, enquanto sua mãe viria a morrer três anos após, fazendo com que Cecília viesse a ser criada pela avó materna de origem açoriana. Segundo relato da própria poeta, "essas e outras mortes [...] me deram desde pequenina, uma tal intimidade com a Morte que docemente aprendi essas relações entre o Efêmero e o Eterno" (GOLDSTEIN, 1982, p.3).

Tendo cursado a Escola Normal, formou-se professora primária, e começou a trabalhar no magistério antes mesmo que completasse os dezoito anos de idade. Neste mesmo período, mais especificamente em 1919, publicou seu primeiro livro de poesia, denominado Espectros, que mostra uma poeta "mais preocupada com a estética formal do que com o sentimento, [...] de algum modo influenciada pelo parnasianismo" (GOUVEIA, 2002, p.83).

Os livros subsequentes, Nunca Mais... e Poema dos Poemas e Baladas para El-Rei, publicados em 1923 e 1925, apresentam, de forma mais evidente, características simbolistas, além de trazerem alguns elementos essenciais da poesia madura de Cecília Meireles: "a consciência da fugacidade do tempo, [...] a consideração da vida como sonho, a melancolia, um toque verlaineano na pintura de ambientes penumbrosos" (DAMASCENO, 1967, p.14).

Em 1922, a poeta casou-se com o artista plástico português Fernando Correia Dias, com quem teve três filhas. O casamento seria interrompido no ano de 1935, em função do suicídio do marido; a poeta casou-se novamente em 1940 com o professor e engenheiro Heitor Grilo.

Desde o início do exercício do magistério, Cecília Meireles desempenhou relevante atividade em prol da Educação. Na década de 1920, a poeta apresentou a tese denominada $O$ Espírito Vitorioso, com o objetivo de assumir uma vaga de professora de literatura na Escola 
Normal do Distrito Federal. A tese trata de questões pedagógicas, faz um traçado da produção literária em Portugal e no Brasil e aborda o papel da literatura na formação dos jovens estudantes, cuja ideia central seria apresentar a literatura como "verdadeiro reflexo das idas e voltas da trajetória humana", com "função formadora e humanista" (GOLDSTEIN, 2007, p.237).

Em 1938, o livro Viagem é premiado pela Academia Brasileira de Letras. O prêmio dado a Cecília Meireles gerou polêmica no meio literário, em função de ser uma obra não alinhada ao panorama modernista então dominante na cena literária brasileira. Conforme Darcy Damasceno, Viagem levou muitos a considerarem que a poeta seria uma autora mais alinhada à Portugal que ao Brasil, exatamente por não apresentar características nacionalistas e anedóticas tão valorizadas pelos modernistas brasileiros. Damasceno acrescenta ainda sobre Viagem:

\begin{abstract}
Mais que a temática explorada ou a revalorização dos sistema versificatório, influía nos equívocos de julgamento o tecido filosófico da autora, que lhe determinava a ascética disciplina e lhe propunha indagações essenciais[...]. Algumas dessas indagações perdurariam nos livros posteriores, constituindo um veio inesgotável para sua poesia; outras, se solucionadas, custariam o preço de amargura e desencanto. A brevidade da vida, a incompreensão humana, a descrença religiosa ganham desde então maior relevo e se fazem motivo de contínua reflexão. (DAMASCENO, 1967, p.20)
\end{abstract}

Vê-se, a partir deste relato, a indicação da presença de um “tecido filosófico", que será fundamental em sua obra posterior. Em Viagem, o estilo da poeta se consolida "trazendo toda a sua inquietação mística para um plano mais próximo da realidade cotidiana, que, no entanto, aparecerá sempre como alegoria" (NETO, 2001, p.xxxii).

Na década de 1940, a poeta irá publicar as obras: Vaga música (1942), Mar absoluto (1945), Retrato natural (1949). Na década seguinte, surgem novas publicações, dentre elas, aquela que talvez seja a mais conhecida do grande público: Romanceiro da Inconfidência (1953), que é uma espécie de "reconstrução lírica e épica de um episódio central da identidade brasileira" (NETO, 2001, p.1) - a Inconfidência Mineira.

O último livro de poesias publicado ainda em vida pela poeta foi Solombra, no ano de 1963; a publicação é introduzida pela seguinte epígrafe: 
A palavra Solombra é "uma forma do português arcaico derivada da expressão latina sub illa umbra, "sob aquela sombra" (HANSEN, 2007, p.33), e esta imagem paira sobre os poemas da obra, permeada por uma atmosfera de melancolia, solidão, morte, sonhos e uma relativização da realidade:

\footnotetext{
Eu sou essa pessoa a quem o vento chama, a que não se recusa a esse final convite, em máquinas de adeus, sem tentação de volta.

Todo horizonte é um vasto sopro de incerteza. Eu sou essa pessoa a quem o vento leva: já de horizontes libertada, mas sozinha.

Se a Beleza sonhada é maior que a vivente, dizei-me: não quereis ou não sabeis ser sonho? $\mathrm{Eu}$ sou essa pessoa a quem o vento rasga.

Pelos mundos do vento, em meus cílios guardadas vão as medidas que separam os abraços. Eu sou essa pessoa a quem o vento ensina: "Agora és livre, se ainda recordas."
}

(MEIRELES, 2001, p.1273)

Neste poema, pode-se perceber a condição de fuga da realidade, a partir do chamamento do vento, que leva o sujeito poético a se libertar, ainda que refém da solidão. Há ainda a referência à "Beleza sonhada" que seria "maior que a vivente", e indaga ao leitor interlocutor, se ele não sabe ou não deseja que seja sonho; um questionamento que sugere a certeza de que se trata de um sonho.

Se Viagem seria a primeira obra de Cecília Meireles a apresentar, de forma mais evidente, as características que serão a marca de sua poesia, pode-se perceber que é Solombra, última obra da poeta, que irá apresentar com clareza o sentimento de "ausência do mundo" indicado pela poeta. Sobre a trajetória da poeta, desde Viagem até Solombra, Leila Gouvêa escreveu:

Esse derradeiro canto espectral da morte, último livro publicado em vida da autora e em época já bem distante do modernismo (1963) - em que retoma o ritmo inaugural do alexandrino, afastado antes em quase toda a obra de maturidade -, traz a austera depuração formal de uma linguagem poética que caminhou lentamente da dicção neo-simbolista da obra imatura para a economia verbal e o despojamento modernos que emergem desde Viagem. (GOUVÊA, 2008, p.214) 
Posteriormente à morte de Cecília Meireles, ocorrida no ano de 1964, poemas que haviam sido reunidos pela poeta sob títulos específicos foram publicados em diversas antologias, sendo a última editada pela Nova Fronteira no ano de 2001.

\subsection{0 tema do sonho na obra}

Para tratar da temática do sonho na obra de Cecília Meireles serão utilizados poemas incluídos na coletânea denominada Sonhos, presente na antologia anteriormente citada; os poemas são: Sonhei um sonho, Em sonho anunciam a minha morte e Aqui estou nos vales da terra. Os três poemas abordam o tema do sonho e sua relação com a realidade perceptível, e permitem ainda a associação de algumas ideias expostas com teorias filosóficas e literárias anteriormente apresentadas.

Em uma das crônicas de Cecília Meireles, de nome Escolha o Seu Sonho, reunidas em livro homônimo publicado no ano de 1964, e que reunia crônicas escritas para um programa de rádio, a poeta propõe que:

Devíamos poder preparar os nossos sonhos como os artistas, as suas composições. Com a matéria sutil da noite e da nossa alma, devíamos poder construir essas pequenas obras-primas incomunicáveis, que, ainda menos que a rosa, duram apenas o instante em que vão sendo sonhadas, e logo se apagam sem outro vestígio que a nossa memória. (MEIRELES, 1996, p.116)

A poeta apresenta a ideia de que deveríamos poder - "como os artistas" - ser capazes de construir o sonho, de forma que criássemos nossas próprias "pequenas obras-primas". A ideia de que no sonho fôssemos capazes de estabelecer nossa própria história é muito semelhante à ideia de Jorge Luis Borges, anteriormente apresentada, de que o sonhador seria uma espécie de dramaturgo.

A diferença é que, na visão idealizada de Cecília Meireles, o melhor seria se pudéssemos, de forma voluntária, exercer o papel de criadores da matéria onírica, e não, como sucede, que os sonhos surgissem de forma autônoma durante o sono. Essa possibilidade criativa a partir de elementos oníricos pode ser vista como uma analogia com o trabalho artístico que utiliza o sonho como técnica na elaboração poética, o devaneio do poeta como viabilizador da sua obra.

De toda forma, Cecília Meireles, ao nos apresentar a possibilidade de que o sonho deveria ser resultado de uma decisão voluntária, indica a ideia de que o sonho poderia ser diferente do que é. De forma semelhante, a realidade vivida durante o período da vigília, 
normalmente, não é aquela que idealizamos, há sempre um quê de desencanto com os fatos cotidianos.

Analisando poemas de Cecília Meireles que tratam do sonho, podemos observar que há um olhar sobre a realidade e à forma como ela pode ser confrontada. Ao final da crônica, a poeta faz o convite, entre parênteses, como quem cochicha ao leitor: "(que gostaria você de sonhar esta noite?)" (MEIRELES, 1996, p.117); um convite a todas as possibilidades, um convite à liberdade.

A coletânea Sonhos reúne quarenta e dois poemas escritos entre os anos de 1950 e 1963, período imediatamente anterior à morte da poeta e apresenta proximidade temática com o último livro publicado pela poeta: Solombra.

Em razão da associação direta com o elemento do sonho, o primeiro poema analisado é Sonhei um sonho, poema de poucos versos, mas que permite uma visão representativa da abordagem do tema.

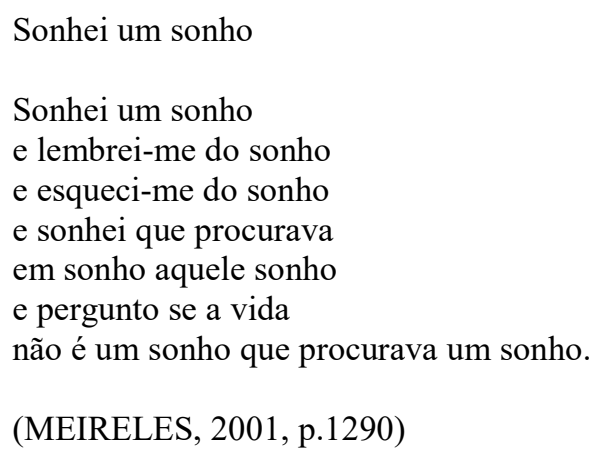

O poema se inicia com a repetição do título, e a repetição é elemento marcante do poema, a utilização - e reutilização - da palavra "sonho", ou o verbo de mesmo radical, em quase todos os versos, e por vezes por mais de uma vez no mesmo verso, leva à sensação de movimento circular, em que sempre retomamos o ponto anterior: sonhar e lembrar e esquecer e sonhar... A circularidade é enfatizada com a conjunção "e" que conecta toda a ação contida no poema, como se todas as ideias estivessem unidas, de mãos dadas.

Escrito na primeira pessoa do singular, o poema apresenta um tom de reflexão, em que a ideia do sonho tem o papel central. Logo no primeiro verso, é estabelecido pelo sujeito poético de forma inequívoca: "Sonhei um sonho"; neste momento, não há dúvida do que ocorreu, mas à sequência, o transcorrer dos versos indicará que a certeza não será a tônica do poema.

O que foi sonhado é lembrado e esquecido, como algo que não teria tanta importância para ser mantido como uma lembrança, algo cuja natureza seria descartável, ou mesmo 
desprezável. No entanto, na quarta estrofe se inicia o relato do sonho, no qual há a declaração: "e sonhei que procurava / em sonho aquele sonho"; portanto, um sonho que conduz a outro, um sonho cuja perspectiva é perseguir outro sonho - "aquele sonho" -, que poderia ser o sonho indicado no primeiro verso e esquecido no terceiro.

É a partir desta procura por um sonho perdido que somos conduzidos à conclusão do poema, quando, então, o sujeito poético revela sua angústia, fazendo um questionamento para si mesmo, mas que recebemos como nosso, de todos: "e pergunto se a vida / não é um sonho que procurava um sonho". A utilização do tempo presente "é" afirma a certeza, enquanto o tempo imperfeito "procurava" indica dúvida quanto ao êxito.

A vida poderia ser então uma espécie de sonho, em que a busca por uma quimera, nunca atingível, seria a sina de todos, sempre a procurar algo que está no plano do sonho. A pergunta fica sem resposta, e o leitor fica com a dúvida.

A dúvida remanescente traz em si a inquietação de se entender o que seria o sonho, em contraposição com a vida - ou a realidade. Seria a vida como "aquele sonho" que "procurava um sonho"? Em Platão, vimos que, tanto durante o sonho como durante a vigília, há dificuldade em não reconhecer as situações ali vividas como reais. No poema de Cecília, a diferença é que, após o sonho terminado, aquele que sonha, já desperto, efetua uma analogia entre os estados e os propõe como possivelmente iguais.

No poema, percebe-se uma aproximação da perspectiva proposta por Schopenhauer, de que toda a vida seria um sonho, porém no caso de Sonhei um sonho, a vida seria um tipo específico de sonho, aquele que "procurava um sonho". No poema, há a pergunta sem resposta, mas permanece a interrogação quanto ao verdadeiro sentido da realidade da vida, quanto aos objetivos estabelecidos por cada um, numa busca incessante por algo que pode de fato não ser nada além de um sonho, um sonho procurado por outro sonho, a própria vida.

O segundo poema a ser analisado tem como título Em sonho anunciam minha morte, no qual estão presentes alguns dos temas constantes do último livro publicado pela poeta, Solombra.

Em sonho anunciam minha morte

Em sonho anunciam a minha morte:

as pessoas falam umas para as outras, propalam, propagam, divulgam para longe a minha vaga morte, nas vozes vagas de um tempo vago.

$\mathrm{Na}$ vigília estamos próximos e claros, sem dubiedade, 


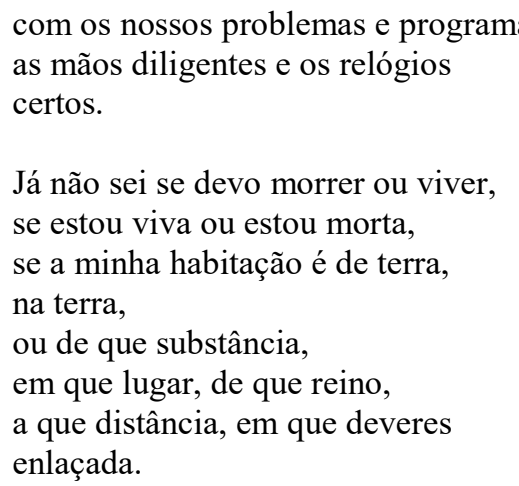

(MEIRELES, 2001, p.1314)

O primeiro verso já determina abertamente do que se trata o poema, com a sentença “Em sonho anunciam a minha morte:", fica estabelecido que há um sonho e que nele há o anúncio da morte do sujeito poético. O emprego de dois pontos como sinal de pontuação, indica que, posteriormente, haverá o enunciado deste sonho, a apresentação da forma como ocorre o anúncio da morte.

Os versos subsequentes mostram como ocorre o anúncio da morte, "pessoas falam umas para as outras / propalam, propagam”; há, portanto, a existência da notícia da morte, e esta notícia é disseminada pelas "pessoas" para muitas outras pessoas. Então o anúncio é divulgado "para longe", e a morte é tratada como "a minha vaga morte" e há a repetição da utilização do adjetivo vago: "nas vozes vagas de um tempo vago".

Se por um lado, o adjetivo vago indica um lugar indeterminado, indefinido, cuja ideia estaria relacionada com aquela introduzida pelos versos anteriores, onde há a propagação do anúncio "para longe"; por outro lado, o adjetivo vago passa a sensação de incerteza, de algo confuso, que não possibilita segurança quanto à sua realidade. A partir desta segunda possibilidade, podemos considerar que a condição de vagueza, seja do tempo, da morte ou das vozes leva ao questionamento da realidade contida nestes elementos, que, ainda que, estejam no âmbito do sonho parecem distantes do sujeito poético, seja pela distância, seja pela incerteza.

A segunda estrofe é escrita na primeira pessoa do plural, incluindo o leitor na conjuntura. Há referência direta ao período da vigília, e, em contraponto à primeira, deixa logo estabelecido que, neste período, "estamos próximos e claros", em oposição direta ao estabelecido anteriormente, onde impera o "longe" e o "vago". E a ideia de uma realidade inexorável é confirmada no segundo verso com a utilização da expressão "sem dubiedade", ratificando que seria certo, sem dúvida. 
Nos versos seguintes, no entanto, a constatação da certeza da realidade é feita com tom desiludido: "com os nossos problemas e programas, / as mãos diligentes e os relógios / certos". Ao deixar o último verso com apenas uma palavra, confere ênfase à palavra "certos", impondo à realidade o aspecto de certeza, ainda que não traga em si algo necessariamente positivo.

A última estrofe volta a representar a perspectiva do sujeito poético, na primeira pessoa do singular. É o retorno da dúvida exposta na primeira estrofe, relativa ao sonho do anúncio da morte, mas que agora regressa durante a vigília. E a dúvida ganha ares de desalento. O sujeito poético não sabe se deve "morrer ou viver", se está "viva" ou "morta", questionando, portanto, se a realidade vivida durante a vigília é de fato real e pode ser considerada vida.

A dúvida sobre sua morada expõe a possibilidade de somente se encontrar na morte o abrigo verdadeiro a ser obtido, ao indicar que sua habitação poderia ser "na terra". E a dúvida existencial permanece ao questionar sobre sua "substância", seu "lugar", "reino", retoma a questão da "distância", para finalmente interrogar "em que deveres enlaçada". Os "deveres" nos remetem à ideia de "problemas" e "programas" expostos na segunda estrofe, o que poderia significar uma contestação às tarefas obrigatórias existentes durante a vigília, cuja importância é aparentemente nula para a essência da poeta, que não encontra mais neste lugar, o seu lugar.

O poema Em sonho anunciam a minha morte permite verificar elementos sugeridos por Maurice Blanchot, quando diz que "aquele que sonha [...] é o pressentimento do outro, o que não pode mais dizer eu, o que não se reconhece em si nem em outrem” (BLANCHOT, 2011, p.293). No poema, o sujeito poético não sabe se está morto ou vivo, qual sua habitação, qual sua substância, seu lugar, seu reino; não se reconhece mais. Enquanto no sonho, anunciam sua "vaga" morte, na vigília, sua morte já está decretada, posto que não se identifica com nada, nem em nada.

Outro aspecto a ser notado é a percepção do real, que, no poema, se apresenta "claro", mas que ainda assim não permite que se conclua que essa realidade é a do sujeito poético, imerso na dúvida quanto à sua existência. Neste ponto, há uma diferença existente entre esta percepção e aquela proposta por Berkeley fundada na ideia de que o que é perceptível, e, portanto, realizado na mente, seria real. No poema, ainda que esta realidade possa ser verificada na mente, há o questionamento de sua certeza, já que a dúvida, que aparentemente não haveria, permanece no sujeito poético, como se a própria mente não pudesse ser garantia de verdade. 
O terceiro poema, em análise, é Aqui estou nos vales da terra, poema que mantém a utilização da primeira pessoa do singular e que apresenta elementos de percepção da realidade, durante o período da vigília.

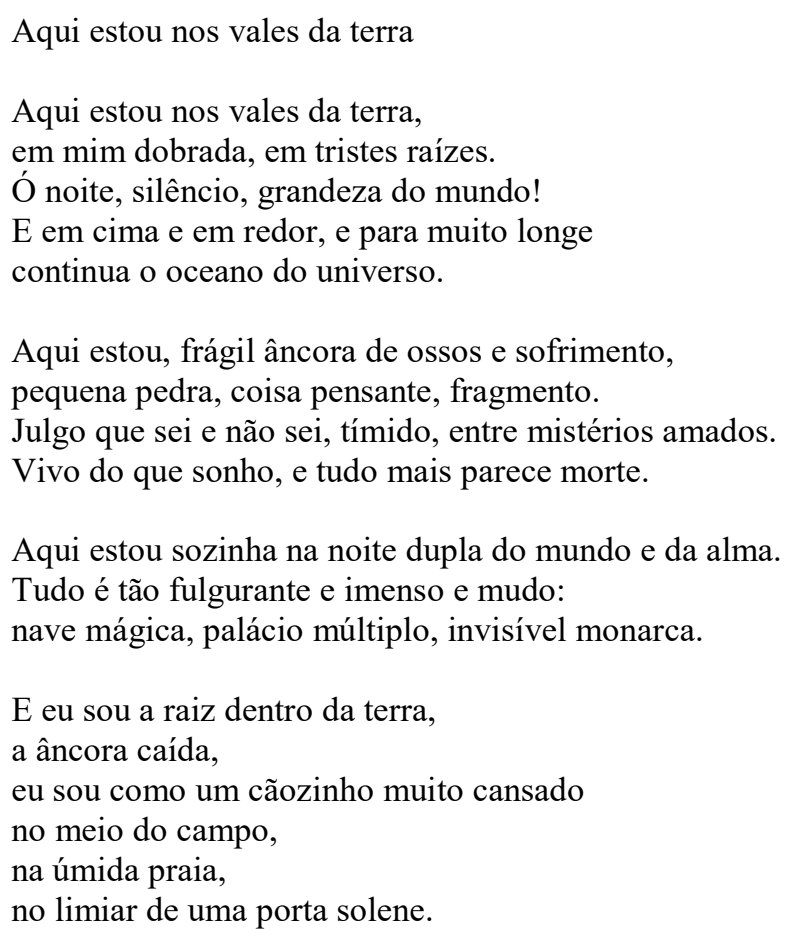

(MEIRELES, 2001, p.1309)

O sujeito poético indica no primeiro verso do poema o lugar onde está situado, e se encontra "nos vales da terra", como a representar que não está apenas na terra, mas em um vale, ou numa espécie de buraco, no feitio de um esconderijo. Ideia que é reforçada no segundo verso, quando afirma "em mim dobrada, em tristes raízes"; a imagem de alguém dobrado leva a pensar na situação de encolhimento, talvez naquilo que é conhecido como posição fetal. Na sequência, a representação da noite e do silêncio como "grandeza do mundo!", demonstram uma tendência a considerar que o mundo se engrandece, quando tudo está parado, quieto. Mas enquanto há noite aqui, em outros sítios, longe, “continua o oceano do universo".

A segunda estrofe retoma o sentimento de ensimesmamento, sob um ponto de vista de fragilidade e desencanto, ao propor-se uma "frágil âncora de ossos e sofrimento" e ampliar sua pequenez, que ainda que "pensante" não passa de "fragmento", ou algo partido, incompleto, despedaçado. O sujeito poético acrescenta que é iludido ao pensar que sabe algo e, em sua timidez, reconhece que seus amores não passam de "mistérios". É então, no quarto 
verso, que expõe a sua realidade: "vivo do que sonho"; ou seja, somente ao sonhar, sente-se vivo, enquanto o que resta além disso "parece morte".

Prossegue reafirmando, na estrofe seguinte, sua condição de solidão, ante a duplicidade existente entre as noites: "do mundo" e "da alma". E é nesta situação, que tudo se transfigura e se apresenta de feitio ao mesmo tempo "fulgurante", "imenso" e "mudo". Uma oposição ao sujeito poético que, anteriormente, se colocava como pequeno e fragmentado, mas que não era mudo, mas "pensante". O mundo seria então a citada "nave mágica" em que haveria um "invisível monarca". Retomando o verso anterior, este "monarca" que comanda a imensidão de um "palácio múltiplo" seria então não só "invisível”, mas também "mudo", e assim sendo, não se torna presente, deixando a sua volta o sentimento de solidão permanente.

No final do poema, o sujeito poético expõe sua condição de total isolamento perante a imensidão do universo que o rodeia: "sou a raiz dentro da terra"; retoma na sequência a imagem da "âncora", que, se antes era feita de "ossos e sofrimento", agora, encontra-se "caída". Ao associar a imagem deste verso com a anterior referência à "dentro da terra", somos levados a perceber algo como um sepulcro.

E, nesta condição, o poeta se percebe como "um cãozinho muito cansado", imagem de fragilidade e desencanto, "no meio do campo", num espaço aberto e solitário, mas "no limiar de uma porta solene". A palavra "solene" passa a percepção de algo respeitoso, imponente, numa imagem que pode remeter à ideia de morte, mas que também pode ser uma referência ao universo onírico, que é o que lhe resta de vida, enquanto nesta condição de isolamento e solidão.

Ao considerar o poema como um todo, podemos observar um confronto entre uma realidade de dimensões grandiosas, mas silenciosa, e o sujeito poético pequeno, frágil, despedaçado, mas que não está mudo e que pensa. No seu pensamento, o poeta percebe que, perante a realidade assustadora, somente o sonho lhe permite viver, mais especificamente no sonho acordado, ou no devaneio, que surge na sua introspecção, durante o silêncio da noite.

Conforme indicado por Bachelard (2009, p.144), no devaneio residiria a clareza de consciência que irá permitir a fuga do real, e no poema Aqui estou nos vales da terra, esta fuga onírica do real surge como possibilidade única, como a última alternativa perante uma realidade que se demonstra vazia de vida.

Nos poemas aqui analisados, a "ausência do mundo" - que a própria Cecília Meireles definiu como seu principal defeito - está presente. Há neles um sentimento de perceber o sonho - inclusive enquanto devaneio - como uma outra realidade possível, uma realidade 
onde ainda reside alguma esperança, enquanto se vive um desencanto com a realidade do período da vigília.

Pedindo licença para discordar da poeta, que definiu este sentimento de "ausência" como um defeito, pode-se entender que a percepção do sonho como elemento integrante da vida, que permite a confrontação com outros universos e imaginários, faz com que se possa fruir outras possibilidades e encontrar na realidade da vigília, momentos de outra vida possível, na imaginação e no inconsciente. 


\section{CAPÍTULO 3}

\section{A POÉTICA DOS SONHOS EM JORGE LUIS BORGES}

No prólogo de seu Livro dos Sonhos - uma antologia de obras de origens e épocas diversas ligadas à temática do sonho - Jorge Luis Borges apresenta uma tese, que teria sido inspirada em um ensaio do final do século XVII, escrito pelo inglês Joseph Addison. Segundo essa tese, a qual Borges anuncia estar de acordo, os sonhos seriam "o mais antigo e não menos complexo dos gêneros literários" (BORGES, 2013, p.3).

\subsection{Percurso da obra}

Em sua obra literária, é recorrente a utilização de símbolos como: espelhos, tigres, labirintos, bibliotecas; além da presença constante de referências a teorias filósoficas. Neste capítulo, o sonho, outro elemento comum em diversos poemas e contos, será abordado no intuito de observar seu emprego como procedimento literário, na criação da identidade poética do autor.

Desde sua primeira obra, o livro de poesias Fervor de Buenos Aires, publicado no ano de 1923, e cuja temática primordial é a capital portenha - seus espaços e hábitos -, é possível verificar a presença da referência ao elemento sonho em oito poemas. No poema Amanecer, a própria cidade de Buenos Aires, inspiração do livro, tem sua realidade problematizada nos versos: “y si esta numerosa Buenos Aires no es más que un sueño" (BORGES, 2011b, p.16). No mesmo poema, anteriormente, há a referência a conjecturas dos filósofos Schopenhauer y Berkeley de que "el mundo es una actividad de la mente, un sueño de las almas" (BORGES, 2011b, p.16).

No prólogo da edição de 1969 de Fervor de Buenos Aires, Borges discorre sobre a percepção de sua relação com o jovem escritor de 1923, e indica que "aquel muchacho [...] ya era essencialmente [...] el señor que ahora se resigna o corrige"; e acrescenta: "Fervor de Buenos Aires prefigura todo lo que haría después” (BORGES, 2011b, p.16). Em que pese algum possível exagero nesta afirmativa, no que se refere ao tema do sonho, esta espécie de prefiguração está presente.

Seus primeiros poemas foram influenciados pelo movimento vanguardista conhecido como Ultraísmo, originado na Espanha em 1918. Sobre este movimento, Borges escreveu inclusive um artigo na revista Nosotros, denominado Ultraísmo, em que faz críticas ao Modernismo hispânico, e apresenta características do novo movimento. Ainda que, 
posteriormente, Borges tenha abandonado as premissas deste movimento, e tenha externado sua insatisfação de ter participado dele, importante notar que:

El ultraísmo fue, en definitiva, un pequeño movimiento, que tuvo, sin embargo, un enorme valor en la historia de la literatura argentina al proclamar, por un lado, de un modo neto y sin fisuras, la liquidación del programa modernista y de todas sus derivas postmodernistas (PRIETO, 2011, p.359)

De alguma maneira, a partir desta ruptura, a literatura hispano-americana do século $\mathrm{XX}$, e em especial a argentina, pôde seguir um caminho independente daqueles vigentes na literatura espanhola. Conforme Noé Jitrik, o movimento vanguardista na América Latina passaria por dois momentos: o primeiro, de confronto com a estrutura vigente, utilizando-se de uma atitude de denúncia do código então utilizado; e o segundo momento, seria marcado pela criatividade na busca por uma poética própria (AZZETTI, 2011, p.25-26).

Jorge Luis Borges será, então, uma espécie de condutor deste movimento ao redirecionar sua poesia e, posteriormente, seus contos para uma visão mais metafísica, intimista, mas de tom universal e menos localista, ainda que estas características já sejam perceptíveis mesmo nos primeiros livros da década de 1920, claramente relacionados ao ambiente portenho. Nos livros subsequentes, a cor local não irá desaparecer, mas segundo Jaime Alazraki "lo central será ahora la reflexión filosófica, sus preferencias literarias y las paradojas de la cultura" (ALAZRAKI, 1977, p.453).

Há então três elementos fundamentais para o entendimento da literatura borgeana: suas referências filosóficas, os escritores que o influenciaram e aspectos da cultura universal. Considerando este período como uma espécie de maturidade da sua escritura, alcançada a partir dos anos 1940, pode-se chegar aos temas que irão estar presentes em sua obra:

\footnotetext{
Los temas que prescriben el proceso de abstracción y profundización metafísica en la poesía borgeana en la etapa que llamamos madurez, pueden ceñirse paradigmáticamente a las lucubraciones sobre los tópicos recurrentes desarrollados por la filosofía desde su nacimiento cinco siglos antes de la era cristiana, tales como la muerte, desprendida de una inquisición sobre la vida; el tiempo y su sucedáneo, la eternidad; el sentido del mundo; el destino del hombre, entre otras inquietudes, que en Borges se desplazan sobre la soledad metafísica del desencanto y la frustración (AZZETTI, 2011, p.87)
}

A discussão na poesia de temas tão afetos à Filosofia será observada também nos contos. Interessante observar é que, em sua obra, apesar da utilização destes temas, não é tarefa fácil relacioná-lo com uma determinada escola filosófica, sendo comum que estudiosos distintos o classifiquem em escolas antagônicas. No entanto, o que certamente Borges fez foi 
“incluir ideas filosóficas en sus cuentos como ningún otro lo ha hecho" (PALMA, 2010, p.65).

No âmbito da prosa, a utilização do conto como gênero preferido, em vez do romance, pode ter se dado por várias razões, o próprio escritor sugeriu algumas possibilidades que vão desde sua preguiça em escrever romances até o fato de o conto estar mais associado à fábula (BRESCIA, 2011, p.814). Seja como for, a utilização deste gênero, especialmente em narrativas de cunho fantástico, irá se expandir por toda uma geração de escritores argentinos, entre eles Julio Cortázar, Adolfo Bioy Casares e Silvina Ocampo.

\subsection{O sonho no fazer poético}

O uso do fantástico em contraponto à realidade irá fazer com que o sonho seja um dos temas mais importantes na obra de Borges, seja no diálogo com ideias filosóficas, ou com outras obras literárias. Segundo Alazraki:

\footnotetext{
Para Borges la poesía es una música, un sueño dirigido y un espejo 'que nos revela nuestra propia cara'; [...] que la realidad de crónica es tan empobrecedora como las noticias de los periódicos y que los sueños y los mitos nos devuelven a ese ser que íntimamente somos. (ALAZRAKI, 1977, p.453)
}

O emprego dos sonhos seria então resultado da necessidade do poeta de estabelecer esta confrontação com a realidade, num espaço onde o mito possa, a partir de um espelhamento do observado, trazer novas percepções sobre o observado. Características essas que estariam na gênese da poética de Borges. A poética percebida como "entendimento de poesia - ou de literatura em geral - característico de certo autor, época ou gênero literário, depreensível das obras por meio de análise” (SOUZA, 2006, p.164).

No prólogo ao livro El elogio de la sombra, publicado em 1969, Borges afirma:

No soy poseedor de una estética. El tiempo me ha enseñado algunas astucias: eludir los sinónimos, que tienen la desventaja de sugerir diferencias imaginarias; eludir hispanismos, argentinismos, arcaísmos y neologismos; preferir las palabras habituales a las palabras asombrosas; intercalar en un relato rasgos circunstanciales, exigidos ahora por el lector, simular pequeñas incertidumbres, ya que si la realidad es precisa la memoria no lo es; narrar los hechos (esto aprendí en Kipling y en las sagas de Islandia) como si no los entendiera del todo; recordar que las normas anteriores no son obligaciones y que el tiempo se encargará de abolirlas. Tales astucias o hábitos no configuran ciertamente una estética. Por lo demás, descreo de las estéticas. En general no pasan de abstracciones inútiles; varían para cada escritor $\mathrm{y}$ aun para cada texto y no pueden ser otra cosa que estímulos o instrumentos ocasionales. (BORGES, 2011b, p.100-101) 
Apesar de fazer referência ao termo "estética", informar abertamente que não a possui, demonstrar descrédito por ela, e, inclusive, exemplificar algumas de suas "astúcias" no processo de escrita - que não seriam "estética" -, é importante tentar estabelecer uma distinção entre os termos "estética" e "poética". Conforme Pareyson:

A poética é programa de arte, declarado num manifesto, numa retórica ou mesmo
implícito no próprio exercício da atividade artística; ela traduz em termos
normativos e operativos um determinado gosto, que, por sua vez, é toda a
espiritualidade de uma pessoa ou de uma época projetada no campo da arte. A
estética, pelo contrário, não tem nem caráter normativo nem valorativo: ela não
define [...] normas para o artista [...], longe de prescrever leis ao artista ou critérios
ao crítico, estuda a estrutura da experiência estética e aqui se encontra com o
problema da poética e da crítica. Torna-se objeto da sua reflexão o esforço do artista
para dirigir, segundo leis ou normas, sua própria atividade. (PAREYSON, 1997,
p.11-12)

A partir desta conceituação de "estética" e "poética", e considerando ainda as palavras de Borges, podemos verificar que ele indicou no seu prólogo diversas atitudes que podem ajudar na caracterização de sua poética; e - por que não? - inferir também a existência de uma estética borgeana, que pressupõe seu leitor como elemento fundamental na recriação dos universos imaginados.

Em relação à poética especificamente, pode-se observar, nos textos de Borges, a existência de uma recorrência de assuntos, temas que são decorrentes de todo o arcabouço de leitura do autor, seja ela filosófica ou literária, que traduziria "em termos normativos e operativos" a atividade artística do poeta.

$\mathrm{O}$ conto As ruínas circulares, publicado no livro El jardín de senderos que se bifurcan, é um dos relatos de Borges que aborda a temática do sonho de forma mais direta. Narrado na terceira pessoa do singular, o relato apresenta a história de um homem sem nome, que, sem ser visto, desembarca em uma região não identificada pelo narrador, que apenas indica que o homem vinha do "Sul". Ao chegar à região o homem atinge um "recinto circular", uma espécie de templo sagrado de um deus que "não recebe honra dos homens". Neste local, o homem dorme, e ao dormir, sonha.

Após o primeiro sonho, o homem decide buscar um objetivo, que, segundo o narrador, seria "sobrenatural": o objetivo de sonhar um homem. Após um mês, o homem sonha com um coração que batia na "penumbra de um corpo humano", que, a cada noite, se expandia. E, antes de um ano, o homem enfim "sonhou um homem inteiro", que, no entanto, se mantinha adormecido. 
Quando já perdia as esperanças, sonhou com um deus que recebia sacrifícios num templo circular como aquele em que estava o homem, e este deus lhe prometeu animar o homem sonhado, de forma que todas as criaturas, exceto o próprio deus e o sonhador, pensariam que ele seria real. E, enfim, o homem sonhado despertou.

O sonhador passa a acompanhar seu filho sonhado, por vezes extasiado, e outras vezes, contrariado. Um dia, desperto, lembrou da situação de seu filho de ser meramente um simulacro, "apenas a projeção do sonho de outro homem", e temeu pela humilhação que seu filho sentiria, quando o soubesse. Finalmente, após a destruição do santuário do deus que o auxiliara, o homem percebeu que a morte lhe chegava, mas quando tentou dar fim à sua vida, o homem percebeu "com alívio", “com humilhação" e "com terror", que "ele também era um simulacro, que outro o estava sonhando" (BORGES, 2011a, p.98, tradução nossa).

$\mathrm{Na}$ busca por um sujeito completo, num espaço onde os elementos racional e sensível estejam presentes e imbricados, Borges nos oferece o vazio, o vácuo da essência, a inexistência pura e simples, realizada apenas mentalmente. A realidade poderia ser pensada como uma construção do imaginário, tal como o sonho; mas também poder-se-ia entender o sonho como outra forma de realidade, ou ainda que a realidade fosse uma espécie de sonho de outro plano ainda superveniente. No conto, não há diferença entre realidade e sonho, posto que a realidade é, de fato, criada a partir de outra pessoa que sonha.

O autor propõe uma relativização da realidade, deixando ao leitor a possibilidade de perceber que não necessariamente existe aquilo que se está vivendo. No conto As ruínas circulares, o personagem percebe com alívio - ainda que aterrorizado - a ideia de que ele mesmo se trata de um simulacro, indicando também certa resignação com a sua condição.

Situação que remete à circularidade das ruínas, que se repetem infinitamente, de deuses e templos infinitos, de sonhadores e sonhados, de criadores e criaturas, sempre simulações de um real talvez inexistente, mas que existente enquanto realização mental, como proposto por Berkeley.

A criação literária pode ser considerada como uma espécie de sonho, tendo em vista que nela são apresentados fatos - do cotidiano ou fantásticos -, em que há a possibilidade de participação de outras pessoas - ou personagens -; em todo remetendo a uma espécie de representação. E é nesta possibilidade de representação que o escritor irá trabalhar, utilizando o sonho como base para sua poética, pautando sua escrita na ênfase do imaginário criador de realidades: 
Borges transita los espacios de la irrealidad como una manera de modificar las formas y el mundo que lo circunda. Nos inquieta y llena de preguntas sobre esa manera de conducirnos poéticamente, de introducirnos en su laberinto de ideas, imágenes, aromas y climas, en ese universo de espejos y espejismos [...]. (LABORDE, 2016, p.1-2)

A partir de realidades que se sabem imaginadas, todo o imaginário estabelecido passa a ser real, ou o real seria também uma construção mental, em que não se sabe ao certo quem é o criador e a criatura.

Pode-se estabelecer um paralelo com a construção poética dos sonhos elaborada pelo escritor Julio Cortázar, contemporâneo e conterrâneo de Borges. Em um de seus contos, denominado La noche boca arriba, a trama se desenvolve a partir de um acidente em que um motociclista fica gravemente ferido.

A partir de determinado momento, o motociclista passa a ter um sonho, que, a princípio, poderia se tratar apenas de delírio. No sonho, que é detalhado minuciosamente no conto, o motociclista se vê subitamente em outros tempos, numa selva, sendo perseguido por astecas. As narrativas seguem de forma paralela, até que, ao final, o protagonista passa a considerar que sonho e realidade se inverteram, e encara o sacrifício diante dos astecas como real, enquanto o acidente com a motocicleta é descrito como "mentira infinita" (CORTÁZAR, 2014, p.209).

No conto de teor fantástico de Cortázar, percebe-se a existência de diferentes realidades, em que o sonho é a ligação entre ambas. Diferentemente do conto As ruínas circulares, em La noche boca arriba, as realidades não apresentam uma estrutura hierárquica, elas estão justapostas, em paralelo, e marcadas pela incerteza de quem é o sonhador e de quem seria o sonhado. Conforme Brescia, o próprio Cortázar define esta forma de apresentar o fantástico como uma forma "intersticial”, em que não haveria uma ruptura entre o real e o insólito. Acrescenta ainda, em relação a Borges:

\footnotetext{
Borges había señalado el camino, y la coincidencia es clara: para ambos, la literatura fantástica es equiparable a la ficción misma y su relación con el referente aceptado como real es siempre sesgada. Sin embargo, en Cortázar este volver la espalda a la realidad es una manera de interrogarla desde otro plano, ya que lo fantástico parte de la realidad y no es exógeno a ella. (BRESCIA, 2011, p.2980)
}

Em este sentido, ambos escritores utilizaram o elemento do sonho como parte de sua poética, ao representar outras realidades. Em Borges, são confrontadas não apenas a dualidade sonho e realidade, mas também divino e humano, criador e criatura, autor e personagem, 
imaterial e físico, infinito e finito; mas é o elemento do sonho que faz com que este diálogo se torne possível dentro da obra.

Em Cortázar, o fantástico emerge do sonho, que funciona como uma porta para a realidade paralela, que se apresenta em mesmo nível que a original, como se ocorressem de forma concomitante, sem hierarquias e deixando ao leitor a incerteza quanto ao que seria real e ao que seria sonho. O próprio autor escreveu em sua Obra crítica, a sua impressão pessoal sobre o elemento fantástico na literatura:

\begin{abstract}
Sempre pensei que o fantástico não aparece de forma áspera ou direta, nem é cortante, mas se apresenta antes de uma maneira que poderíamos chamar de intersticial, a deslizar entre dois momentos ou dois atos no mecanismo binário típico da razão humana a fim de permitir-nos vislumbrar a possibilidade latente de uma terceira fronteira [...]. Neste sentido a literatura cumpriu e cumpre uma função pela qual deveríamos agradecer-lhe: a função de nos tirar por alguns momentos dos nossos esquemas habituais e mostrar-nos, mesmo que seja por intermédio de outro, que talvez as coisas não finalizem no ponto em que os nossos hábitos mentais pressupõem. (CORTÁZAR, 1998, p.321)
\end{abstract}

Se em Cortázar, o elemento fantástico que emerge do sonho surge como uma "terceira fronteira", em Borges, não há fronteira, posto que o sonho seria o criador da realidade, que, de forma circular, surgiria a partir de um sonhador. Sobre a função do sonho na obra de Jorge Luis Borges, Jaime Alazraki escreveu:

aunque la vida puede ser un sueño, dentro de ese sueño también nosotros, criaturas del sueño de alguien, soñamos: la narración es un sueño de su creador pero los personajes creados se abandonan a sus propios sueños, o más precisamente: se les permite abandonarse a sus propios sueños. Cuando esto último ocurre, los sueños devienen recurso literario con claros atributos. Su función se define desde la cosmovisión que gobierna el relato, su sentido, a partir de los contextos narrativos en los cuales ha sido inserto. (ALAZRAKI, 1975, p.9-10)

Assim, pode-se perceber que o sonho surge como recurso literário do escritor, que permite ao leitor experimentar a liberdade de se perder em seus sonhos, ao ver a representação dos sonhos dos personagens. A função do sonho atende ao objetivo de permitir que a cosmovisão do escritor seja exposta, o que, no caso de Borges, é todo um conjunto de correntes filosóficas e influências literárias que se mesclam na composição de um relato particular e universal.

Jorge Luis Borges é por muitos críticos considerado o principal nome da Literatura Argentina. Em sua obra, contos e poemas são os gêneros mais frequentes, mas escreveu ainda uma série de ensaios, em que aborda diversos assuntos, em especial, temas literários e de ordem filosófica. Suas opiniões e ideias podem ser verificadas também nas muitas entrevistas que concedeu durante sua vida. 
Perguntado, em entrevista, sobre suas influências no âmbito da Filosofia, o escritor cita os filósofos George Berkeley e Arthur Schopenhauer. Sobre Berkeley, Borges diz que “era um idealista piedoso, já que imaginava Deus como um contínuo sonhador" (FERRARI, 2009a, p.174). Sobre a presença da Filosofia no âmbito da literatura borgeana, conforme a pesquisadora da obra de Jorge Luis Borges, Zulma Mateos:

\footnotetext{
Reiteradamente resalta Borges que no pretende ser un filósofo y, en efecto, su proposito no fue hacer filosofía. Pero el hecho de negarse a si mismo un pensamiento filosófico original no implica que no haya asumido, y tempranamente, una posición filosófica. No se puede pensar que un literato de la profundidad temática de Borges - y que usa constantemente la filosofía como ingrediente literario - carezca de una visión filosófica que articule su pensamiento. (MATEOS, 1998, p.18)
}

$\mathrm{Na}$ mesma entrevista anteriormente citada, Borges afirma que "o sonho é o mais antigo dos gêneros literários, [...] uma peça na qual somos o autor, o ator e o teatro. Ou seja, à noite, todos somos, de alguma maneira, dramaturgos" (FERRARI, 2009a, p.156).

O sonho seria percebido pelo escritor como uma espécie de criação literária, considerando que nele são apresentados fatos - do cotidiano ou fantásticos -, em que há a possibilidade de participação de outras pessoas ou personagens; em todo remetendo a uma espécie de representação.

\subsection{O sonho na poesia}

A seguir, serão analisados três poemas de Jorge Luis Borges, publicados a partir da década de 1960, são eles El Sueño de La Rosa Profunda (1975), Sueña Alonso Quijano de El oro de los tigres (1972) e El Sueño de El otro, el mismo (1964) que tratam diretamente da temática do sonho, desde o título, ainda que a utilização do tema seja recorrente nas obras do autor, desde o seu primeiro livro Fervor de Buenos Aires (1923).

\section{El Sueño}

Cuando los relojes de la media noche prodiguen un tiempo generoso, iré más lejos que los bogavantes de Ulises

a la region del sueño, inaccessible

a la memoria humana.

De esa region inmersa rescato restos

que no acabo de comprender:

hierbas de sencilla botánica,

animales algo diversos,

diálogos con los muertos,

rostros que realmente son máscaras, 


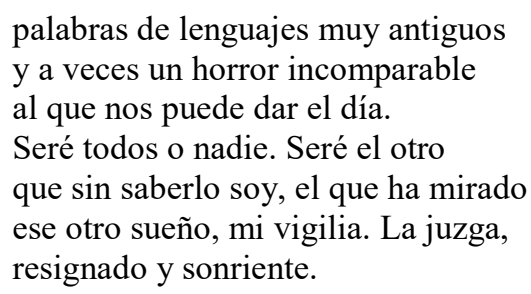

(BORGES, 2011b, p.140)

No poema El Sueño, o sujeito poético estabelece que tudo começará assim que surja um tempo propício, um tempo que virá com os relógios da meia-noite, durante a noite, mas não necessariamente durante o sono, e tampouco com a certeza de que se dará ainda desperto, na vigília. Neste momento, haverá então a possibilidade de se buscar um novo horizonte, que estará mais distante que aquele alcançado pelos marinheiros de Ulisses, em sua Odisséia. E o novo horizonte é o que o sujeito poético denomina como "a região do sonho", que seria então um espaço que a memória humana não pode ocupar.

Se considerarmos que tudo que pensamos está necessariamente ligado a algo que conhecemos, e o que conhecemos faz parte de nossa memória, a "região do sonho" seria aquela que permitiria que encontrássemos algo nunca antes experimentado, algo que não só não encontra par na realidade vivida durante a vigília, mas que também pode ser completamente dissociado desta ideia de realidade.

Na sequência, são apresentados os elementos pertencentes a esta "região do sonho", na qual o sujeito poético vai buscar no seu âmago, restos que estão ali imersos, numa atitude semelhante a de quem explora um navio naufragado no fundo do oceano, e ali encontra relíquias de outros tempos, muitas vezes desconhecidas e surpreendentes. E o sentimento que emana dos "restos" resgatados é a incompreensão, em função de tudo aquilo que se lhe apresenta ser completamente diferente do que sua memória permite reconhecer.

Há então a enumeração das coisas incompreensíveis, de uma forma gradativa, possibilitando que o leitor experimente surpresa semelhante àquela vivida pelo sujeito poético. Parte de elementos básicos de natureza "sencilla" até chegar em um "horror incomparable". E, nesta jornada, apresenta uma espécie de evolucionismo dos elementos: vegetal, animal, humano, e algo além, perturbador. Se ervas e animais estão na esfera do simples e do diverso, a presença do elemento humano transmuta a "região do sonho".

Há diálogos com os mortos e rostos que, diferentemente daqueles vistos durante a vigília, são realmente máscaras, talvez porque, na vigília, as verdadeiras máscaras seriam escondidas com os rostos. Surgem então "palavras de línguas muito antigas", uma busca pela ancestralidade, pela origem dos significados, pelo real significado das coisas. 
E, finalmente, é afirmado que, na "região do sonho", há "a veces un horror incomparable al que nos puede dar el día”. O verso indica que durante o dia se vivem horrores, mas que os vividos "na região do sonho", seriam, algumas vezes, incomparáveis, o que permite inferir que outras vezes os horrores do dia poderiam ser até piores. No entanto, é importante verificar que há aqui a contraposição do "día" com a "media noche" que indica o tempo vivido no poema, nesta oposição poderiam estar ainda o binômio "sonho" e "vigília", "morte" e "vida", ou mesmo, "humano" e "divino".

A razão do "horror" não é descrita, de forma a deixar o leitor com a angústia de algo que não se conhece, mas considerando que este horror surge após o diálogo com os mortos e contato com línguas antigas pode-se perceber que aí pode residir o drama do encontro com uma verdade indesejada, cuja origem pode estar nos antepassados e que só se revela na morte.

Então o sujeito poético determina: "Seré todos o nadie"; uma identidade que inexiste na individualidade vivida durante a vigília, algo que somente se realiza enquanto unidade comum na região dos sonhos, do contrário não é possível existir. E, no espaço da individualidade perdida, é possível assumir qualquer identidade, inclusive a de um outro que o próprio sujeito poético não consegue se reconhecer, mas que, por ser todos, é também ele mesmo, e que deste ponto de vista ambiguamente externo e interno encara, a partir da "região do sonho", o outro sonho que é a sua "vigília".

A perda da identidade do sujeito poético encontra paralelo com a proposição de Bachelard de que o sonhador do sonho perde o próprio "eu". Além disso, neste ponto, se propõe claramente que o período da vigília seria, ele próprio, um outro sonho, seguindo a ideia proposta por Schopenhauer, de que toda a vida seria também um sonho.

Finalmente, a partir da perspectiva externa, o outro julga a "vigília", "resignado y sonriente"; uma percepção marcada pelo conformismo perante a situação, perante uma realidade que de fato pode ter momentos de "horror incomparable", mas que é, na essência, nada além de um outro sonho, uma espécie distinta do sonho vivido durante o sono, mas que acaba sendo encarado de forma "sonriente", uma tranqüilidade que pode parecer inexplicável, mas que se torna aceitável em função do inexorável destino ao qual necessariamente todos ("ou nadie") estamos condenados.

O poema seguinte trata-se de Sueña Alonso Quijano, publicado no ano de 1972, no livro El oro de los tigres: 


\begin{abstract}
Sueño de alfanjes y de campo llano
Y se toca la barba con la mano

Y se pregunta si está herido o muerto.

¿No lo perseguirán los hechiceros

que han jurado su mal bajo la luna?

Nada. Apenas el frío. Apenas una

Dolencia de sus años postrimeros.

El hidalgo fue un sueño de Cervantes

$\mathrm{Y}$ don Quijote un sueño del hidalgo.

El doble sueño los confunde y algo

está pasando que pasó mucho antes.

Quijano duerme y sueña. Una batalla:

Los mares de Lepanto y la metralla.
\end{abstract}

(BORGES, 2011b, p.145)

Neste poema, a citação no título ao nome Alonso Quijano, nome original do personagem Dom Quixote já indica a referência direta à obra de Miguel de Cervantes. Sobre o poema e a relação com Cervantes, Borges explica que "sem dúvida Cervantes foi sonhado por Deus ou pela consciência universal” (FERRARI, 2009b, p.136). Estas informações serão importantes para a compreensão do poema.

Os primeiros versos indicam que um homem acorda durante um sonho que seria “incerto", em que há sabres em um campo, provavelmente de batalha, pois o homem se toca para avaliar se está ferido ou morto. Não há outra possibilidade, não se pode estar simplesmente ileso, tal a realidade a que está exposto durante a jornada sonhada. E, envolto na atmosfera onírica, o homem se questiona se não estaria sendo perseguido por feiticeiros, que teriam lhe rogado uma praga durante o sonho.

A resposta que é dada pelo sujeito poético, mas que pode ser percebida como uma representação do sentimento vivido pelo homem retratado no início do poema. E a resposta é: "Nada. Apenas el frío. Apenas una dolencia de sus años postrimeros". Há então a percepção do vazio que se permanece fora do sonho, um espaço frio em que não resta nada além da indolência dos últimos anos.

Se comparado com o poema El Sueño anteriormente analisado, é de se verificar a existência lá dos pólos "todos/sonho" e "ninguém/vigília", enquanto no poema Sueña Alonso Quijano os pólos são "nada/vigília" e "tudo/sonho", em que é ressaltado o aspecto de que no sonho reside a possibilidade da criação.

Poderíamos perceber aqui ainda um pouco do "horror" do período da vigília, retratado em El Sueño, um espaço em que remanesce a sensação de desencanto, situação que nos remete a mesma ideia expressa no poema Aqui estou nos vales da terra de Cecília Meireles, em que tudo, na vigília, "parece morte". 
Na sequência, inicia-se então a referência à obra de Cervantes, e, então, o sujeito poético apresenta dois níveis de sonho, primeiro o autor, Cervantes, sonha o fidalgo, Alonso Quijano; depois, Quijano sonha Dom Quixote. Esta ideia é semelhante ao poema Sonhei um sonho de Cecília Meireles, em que a vida seria um sonho que procura outro sonho. Cervantes ao escrever (ou sonhar) o fidalgo, faz com que o personagem também procure um sonho, que se realiza por intermédio do Quixote.

Surge então a proposição da confusão do sonho duplo, mas acrescenta que "algo está pasando que pasó mucho antes", uma indicação de que, na região onírica, a referência do tempo não é concreta, e que a realidade ali criada pode sim estar viva, o passado pode estar acontecendo agora, durante o sonho.

O poema é finalizado com a indicação de que Alonso Quijano está dormindo e sonhando, e então, na região de seu sonho, surge uma batalha, em que estão convivendo, concomitantemente, a batalha marítima de Lepanto de 1571 - em que nações cristãs enfrentaram o império otomano - e a "metralla", artefato militar criado muito tempo depois.

É o ponto onde o tempo e o espaço convergem, uma realidade criada e que pode ser tão verdadeira quanto aquela que a inspirou. Um sonho em que os seus protagonistas não sabem que são apenas personagens de um sonho, e o seu sonhador também não sabe que sonha, e que talvez seja ele mesmo, neste momento, fruto do devaneio do poeta que o imaginou.

O terceiro poema trata-se de um soneto, intitulado também El sueño, tal como o primeiro poema apresentado, tendo sido publicado no ano de 1964, no livro El otro, el mismo.

\author{
EL SUEÑO \\ Si el sueño fuera (como dicen) una \\ tregua, un puro reposo de la mente, \\ ¿por qué, si te despiertan bruscamente, \\ sientes que te han robado una fortuna? \\ ¿Por qué es tan triste madrugar? La hora \\ nos despoja de un don inconcebible, \\ tan íntimo que sólo es traducible \\ en un sopor que la vigilia dora \\ de sueños, que bien pueden ser reflejos \\ truncos de los tesoros de la sombra, \\ de un orbe intemporal que no se nombra \\ y que el día deforma en sus espejos. \\ ¿Quién serás esta noche en el oscuro \\ sueño, del otro lado de su muro?
}

(BORGES, 2011b, p.91) 
Neste soneto, publicado antes dos poemas anteriormente apresentados, há a discussão sobre o fenômeno do sonho. Nele, podemos perceber aproximações com as meditações de Descartes, pois o sujeito poético propõe questionamentos ao leitor, no entanto, ao apresentar algumas respostas, não demonstra preocupação com a perspectiva da verdade filosófica, mas com a interpretação do fenômeno do sonho, com a tentativa de encontrar formas de decifrar seus enigmas por meio da linguagem poética. Uma tentativa errática que percorre vários caminhos, destinos, labirintos:

\footnotetext{
Descubrimos en ese laberinto poético muchos caminares fascinantes y a veces aterradores que son los parajes del sueño del poeta. Nos perdemos no sin resistencias en él, no sabemos si encontraremos alguna salida. Su horror y su éxtasis nos penetran, al mismo tiempo que vamos entrando de una palabra a otra palabra, de un verso a otro, de un poema a otro, de un sueño a otro sueño, de una pesadilla a otra [...], de un espejo a otro espejo, de un significante a múltiples significados. (LABORDE, 2016, p.4)
}

Introduz-se o poema apresentando uma proposição lógica sobre o caráter do período de sono como simples intervalo para o repouso da mente, ao questionar a impressão que se tem ao acordar de terem "roubado una fortuna" ou de ser "tan triste madrugar". E incluindo o leitor na angústia da perda que a hora traz, acrescenta que ela "nos despoja de un don inconcebible" e "íntimo". Inconcebível porque não criado, que nos seria inerente e individual, algo como a condição de um deus cuja imaginação seria capaz de criar realidades.

As circunstâncias vividas, mas que são tomadas ao acordar, somente podem ser recuperadas durante a vigília, pelo devaneio, que pode trazer de volta da região dos sonhos como reflexos dos "tesoros de la sombra", de um espaço "intemporal", sem nome e deformado nos espelhos, por ser assim algo criado à semelhança, mas diferente, necessariamente que não é espelho, cujo criador não se reconhece, ou não pode admitir como igual.

O poema é concluído com um novo questionamento que é direcionado novamente ao leitor, ao propor, na segunda pessoa do singular, que identidade o leitor assumirá durante a próxima noite, em um sonho "oscuro", que está do "outro lado de su muro", na região dos sonhos. Esta questão que parece desafiar o leitor a encarar seu sonho, mesmo que sombrio, nos remete ao convite proposto por Cecília Meireles em sua crônica, anteriormente apresentada, em que a autora interroga "(que gostaria você de sonhar esta noite?)" (MEIRELES, 1996, p.117).

No contexto da crônica, a sensação é que há um olhar distinto sobre a realidade, e o questionamento seria como um convite à liberdade de imaginação. No poema de Jorge Luis 
Borges, a impressão é de que o mergulho na região dos sonhos levaria a uma experiência que não é somente uma alternativa à realidade, mas também um espaço onde a experiência atemporal será algo necessariamente inigualável durante a vigília. Uma experiência quase divina de criar outra realidade, em que, ainda que sejamos nós mesmos, jamais será reflexo perfeito do sonhador.

\subsection{Contos de sonhos e sonhadores}

Nos contos, a presença dos sonhos também é tema utilizado com frequência pelo autor, como no conto anteriormente citado As ruínas circulares, que apresenta uma espécie de estrutura da representação do sonho na obra de Borges. Outro conto, cuja composição guarda bastante semelhança, e que ajuda na construção deste sistema de possíveis realidades é Everything and Nothing; publicado no ano de 1960 e que faz parte do livro El hacedor.

$\mathrm{O}$ conto Everything and nothing, como As ruínas circulares, também é narrado em terceira pessoa, e faz referência a uma pessoa na qual "ninguém existia nele". O relato segue delineando a biografia do personagem, indicando o que fez aos vinte anos, os seus hábitos de simulação e a ida para Londres, onde se torna ator, tarefa que lhe proporcionava a alegria de ser alguém, mas que, ao término, lhe remetia de volta à situação de ser ninguém.

Em função desta situação, o personagem passa a imaginar "outros heróis" e "outras fábulas trágicas". Então passa a viver uma dualidade, enquanto seu corpo vive a realidade opaca de sua vida, sua alma se transforma em vários outros personagens: Julio César, Julieta, MacBeth, Ricardo... Durante vinte anos, o personagem narrado vive esta "alucinação controlada" até que é tomado pelo fastio, decide vender o teatro e se transforma num “empresário aposentado".

Após escrever seu testamento, que em nada lembra seus tempos poéticos, o personagem sucumbe, não sem que, antes de morrer, surja uma lenda de que tendo se colocado diante de Deus, reclamou de ter sido tantos, na imaginação, mas, ao mesmo tempo, não ter sido nenhum, recebe a seguinte resposta de Deus, desde um redemoinho: "Tampouco eu sou; sonhei o mundo como tu sonhaste tua obra meu Shakespeare, e entre as formas de meu sonho estás tu que como eu és muitos e ninguém" (BORGES, 2012, p.44, tradução nossa).

Se observados ambos os contos, veremos que, em ambos, a narrativa é relatada em terceira pessoa, por um narrador que não faz parte do enredo. Em ambos os contos, são 
apresentados fatos imaginados nas mentes dos personagens principais. Além disso, ambos os contos retratam o percurso dos personagens até sua morte.

Em termos estéticos, há a apresentação do sujeito que busca encontrar alguma essência. No conto As ruínas circulares, o personagem deseja sonhar um homem, de forma que a existência deste ser sonhado pareça real para ele. $\mathrm{O}$ sonhador sofre com a perspectiva que seu ser sonhado descubra que não existe e que é meramente um simulacro, algo sem essência. No entanto, ao final do conto, o sonhador percebe que ele mesmo também foi sonhado por outro e que, portanto, sem uma essência absoluta.

Situação semelhante pode ser observada em Everything and Nothing, pois o personagem, que não possui essência nenhuma, busca, em suas criações imaginárias, uma forma de se imbuir da alma obtida por aqueles personagens imaginados. No entanto, ao retornar a si, sua essência continua a mesma, nula. Ao final do conto, o personagem - que é revelado se tratar do escritor William Shakespeare - ao dialogar com Deus, descobre que mesmo Deus se sente sem essência, vazio.

$\mathrm{Na}$ busca por um sujeito completo, num espaço onde os elementos racional e sensível estejam presentes e imbricados, Borges nos oferece o vazio, o vácuo da essência, a inexistência pura e simples, realizada apenas mentalmente.

Ainda considerando os contos apresentados, podemos estabelecer algumas analogias entre ambos. Ambos tratam da temática do sonho de forma a indicar que o sonho poderia ser uma espécie de escolha estética, posto que tema recorrente na obra de Jorge Luis Borges.

A partir da discussão da realidade como algo apenas representado na mente, poderíamos, por analogia, considerar que o sonho - aparentemente, uma construção mental poderia representar uma espécie de outra construção de realidade, posto que perceptível. Situação que é observada em ambos os contos analisados, onde a existência remanesce como construção mental do sonho ou do devaneio dos personagens.

A realidade poderia ser pensada como uma construção do imaginário, tal como o sonho, mas também poder-se-ia entender o sonho como outra forma de realidade, ou ainda que a realidade fosse uma espécie de sonho de outro plano ainda superveniente. Em ambos os contos, não há diferença entre realidade e sonho, posto que a realidade é, de fato, criada a partir de outra pessoa que sonha.

Outra confrontação importante a ser observada é que, apesar dos contos apresentarem o sonho como tema, no conto Everything and Nothing, percebe-se que o trabalho de imaginação, entabulado pelo personagem criador de diversos outros, é realizado durante o 
período da vigília, o que indicaria que estaríamos diante de um sonho acordado, diante do devaneio.

No conto Everything and Nothing, a criação - a partir do devaneio - de diversos outros personagens e respectivos universos imaginários, possibilitam ao seu criador a experiência de almas que ele próprio não consegue vivenciar em sua realidade.

Podemos verificar nos contos o interesse em mostrar a não-concretude da realidade, a possibilidade de que ela exista apenas enquanto construção mental, seja pelo sonho ou por exercício de imaginação durante o devaneio.

Outra característica a ser observada é a de relativização da realidade, propondo, de alguma maneira, ao leitor a possibilidade de que o que se está vivendo não necessariamente existe, e que, portanto, talvez não merecesse tanta preocupação conforme a fala de Deus no conto Everything and Nothing, em que o tom de desabafo e resignação da fala, pode levar o leitor a pensar que, se nem mesmo Deus possui em si uma personalidade, por que não buscar no imaginário um refúgio para outras vidas?

De forma semelhante, no conto As ruínas circulares, o personagem percebe com alívio - ainda que aterrorizado - a ideia de que ele mesmo se trata de um simulacro, indicando também certa resignação com a sua condição, situação que remete à circularidade das ruínas, que se repetem infinitamente, de deuses e templos infinitos, de sonhadores e sonhados, de criadores e criaturas, sempre simulações de um real talvez inexistente, mas que existente enquanto realização mental, conforme proposto por Berkeley.

Os contos foram escritos em datas distintas, o primeiro no ano de 1941, e o segundo no ano de 1960. O ser humano Jorge Luis Borges teve sua vida marcada pela cegueira, que o acometeu durante a década de 1950. A diferença de abordagem da temática do sonho, pois no conto Everything and Nothing há uma ênfase no devaneio, ou do sonho acordado, poderia ser um indicativo da necessária ênfase do universo imaginário durante a vigília, visto que o escritor já estava desprovido da visão.

Uma outra forma de entender a representação da realidade na obra de Borges seria aquilo que LIMA (2003) denomina de antiphysis. Originariamente, haveria uma oposição natural entre o mundo da physis - região do natural ou da realidade perceptível - e o mundo da mímesis - espaço da arte, que cumpre um relacionamento de semelhança e diferença com a physis.

No âmbito da mímesis, a obra de arte é convertida pelo olhar humano em "algo semelhante ao esperável por nós, i.é., em algo que é lido de acordo com nossa codificação 
cultural" (LIMA, 2003, p.239), onde a percepção de semelhanças e diferenças é de alguma maneira aceita conforme uma "convenção cultural interiorizada".

Normalmente, na obra de arte a mímesis possibilita que as representações façam com que haja uma identificação do receptor em face do que lhe é apresentado, por meio de um processo de reconhecimento, onde "a concentração em condutas extraordinárias - o heroísmo, a perversidade, o comportamento singular - serve de guia para a experiência do leitor" (LIMA, 2003, p.242).

$\mathrm{Na}$ obra de Jorge Luis Borges, segundo LIMA (2003), ocorreria exatamente o contrário, onde os padrões miméticos e as "simetrias poéticas" são ostensivamente postas em xeque, por meio de uma ironia que impõe a perda das referências. Borges estaria propondo, então, uma inversão da tradição existente nas ficções, em que, ao questionar a mímesis, criando uma antiphysis, em que as correspondências se perdem, acaba, consequentemente, questionando a physis.

A circunstância acima faz com que a ficção no âmbito da antiphysis transforme a vida naquilo que LIMA (2003, p.248) denomina de "experiência de pesadelo", posto que simulada e pertencente a um mundo encadeado de histórias dentro de histórias, ficções geradas a partir de ficções, com a convivência de personagens reais com ficcionais. Dessa "antiphysis borgiana" emerge uma literatura fantástica desapegada do grotesco, mas cujo horror surge pela "aniquilação ficcional da realidade".

O mundo borgiano seria então resultado da "aniquilação ficcional da realidade", onde a supressão da paixão é o que permite a possibilidade de outras realidades, pois a paixão restringe as opções. Sem a paixão, surge o espelho como a centralidade da antiphysis, pois se transforma em gerador de alternativas de realidade. Ou como propõe DE MAN (1976), um espelho gerador de "pseudo-realidade":

\footnotetext{
La invención poética comienza con la duplicidad, pero no termina ahí, pues la duplicidad particular del escritor [...] brota del hecho que él presenta la forma inventada como si poseyera los atributos de la realidad, permitiendo así que ésta a su vez se reproduzca imitativamente en otra imagen reflejada en el espejo que toma la pseudo-realidad anterior como su punto de partida. A esto lo mueve la intención blasfema de atribuir la divina categoría de ser a meros entes. Como resultado, la duplicidad alcanza una multiplicidad de imágenes sucesivas reflejadas. (DE MAN, 1976, p.147-148)
}

O sonho, tal como o espelho, funcionaria portanto como um espaço divino gerador do real, cujo produto é um "desejo que subverte a imagem do real” (LIMA, 2003, p.254). Sonho 
e espelho funcionariam como um labirinto, mas uma espécie de labirinto ao avesso, sem enigmas ou entendimentos subliminares, mas uma referência a si mesmo.

A literatura de Borges - por meio de sua antiphysis - questionaria a Literatura, a realidade e também a paixão, cujo exercício necessariamente é limitador. O espelho, responsável pela formação de duplos, teria uma espécie de raiz comum, que estaria no cerne do texto, a ser encontrado a partir de um labirinto de onde não se deseja sair, mas se encontrar. 


\section{CAPÍTULO 4 SONHOS EM COMUM}

A América do Sul teve grande parte do seu território ocupado por povos oriundos da Península Ibérica, e que viveram na região sob a condição de colonos das metrópoles europeias durante mais de quatro séculos. Na primeira metade do século XIX, diversos processos de independência provocaram o surgimento de novos países, cujas identidades culturais somente seriam consolidadas posteriormente.

Dentre os novos países, Brasil e Argentina se tornaram, com o decorrer do tempo, as principais economias da região, ganhando importância nos cenários regional e mundial. Apesar disso e da proximidade geográfica, muitas vezes parecem países extremamente distantes, especialmente no aspecto cultural, como se a barreira linguística fosse muito maior do que realmente se apresenta, tendo em vista a evidente proximidade entre os idiomas português e espanhol.

Ainda no século XIX, as literaturas brasileira e argentina seguiriam caminhos independentes, mas semelhantes, em função da tendência presente no movimento romântico de buscar estabelecer uma identidade nacional e uma cultura autônoma nos países recémcriados praticamente por decreto. Apesar das semelhanças na abordagem, o isolamento entre as culturas dos países vizinhos seguirá sendo uma constante.

Nesta conjuntura, de países vizinhos, mas distantes, nasceram dois escritores, nas capitais e principais cidades desses países, que irão ter grande representatividade nas suas respectivas literaturas nacionais: Jorge Luis Borges, em 1899, em Buenos Aires; e Cecília Meireles, em 1901, no Rio de Janeiro.

\subsection{Herança lusitana}

Contemporâneos, alguns aspectos da vida de ambos guardam semelhanças como a ascendência lusitana, que enquanto em Cecília Meireles é exaltada e comprovada, pois era neta de açorianos, em Borges é uma possibilidade, que, no entanto, era costumeiramente reiterada pelo escritor que escreveu os seguintes versos sobre essa possível herança:

Los Borges

Nada o muy poco sé de mis mayores 


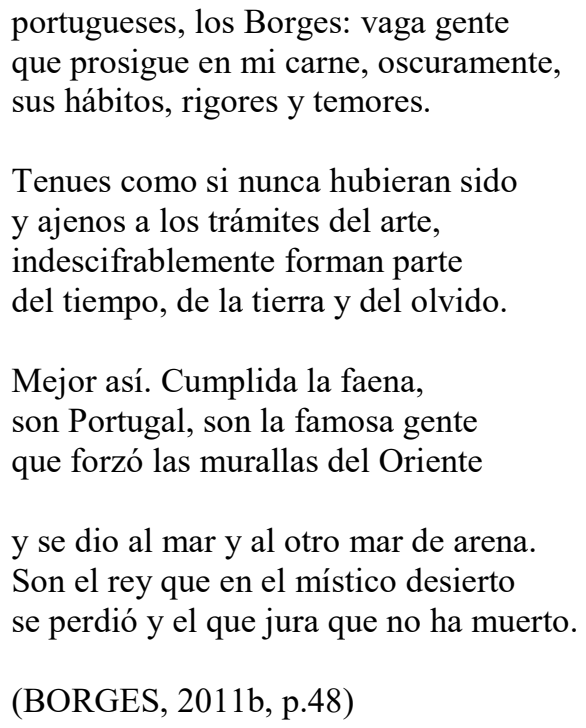

O espírito lusitano normalmente associado com sentimentos de desprendimento, de destemor, em que o mar se tornou um condutor da viagem rumo ao sonho de descobrimento pode se referir a uma tentativa do poeta de encontrar em si a semente da sua inquietude frente à realidade, um sebastianismo que não espera encontrar um messias, mas um sonho que possibilite a construção de uma nova realidade.

Ademais, em seu período mais glorioso, a nação portuguesa teve o sonho como importante protagonista da vida política e social do império:

a concepção da vida como sonho não era particular de Portugal. Encontra-se em textos ibéricos, católicos e, com alguns diferentes matizes, mesmo protestantes. A particularidade portuguesa não era a presença dos sonhos, mas sim seu papel preponderante na formulação do projeto de monarquia e nação, e sua permanência ao longo dos séculos. (LIMA, 2010, p.280)

A ênfase numa ascendência portuguesa poderia indicar, ainda, a busca por uma condição mais multicultural na sua obra, reduzindo a cor local que apresentou nos primeiros textos. A referência frequente a aspectos da cultura ocidental, buscando uma escrita que tenha uma abrangência mais ampla é uma característica importante na trajetória da obra de Borges.

\subsection{Identidade nacional}

Em texto publicado no ano de 1953, denominado $O$ escritor argentino e a tradição, o autor apresenta sua visão sobre a problemática de se definir quais seriam as características necessárias para definir um escritor argentino, ou sua literatura como argentina. 
No ensaio, Borges critica a chamada poesia gauchesca, que apresentaria elementos artificiais em relação à poesia popular produzida pelos gauchos, especialmente no que se refere à linguagem utilizada - profusa em expressões regionais - e aos temas.

O autor considera que seria um "equívoco" a crença de que a poesia argentina somente deva assim ser considerada caso apresente um evidente matiz local, inclusive porque um verdadeiro nativo costuma prescindir da "cor local", posto que para ele aspectos desse tipo lhe pareçam naturais.

Borges apresenta então o que denomina de uma "mínima confidência", em que faz referência a suas obras iniciais e compara com uma obra recentemente publicada naquele período:

\begin{abstract}
Durante muitos anos, em livros agora felizmente esquecidos, tratei de transcrever o sabor, a essência dos bairros afastados de Buenos Aires; naturalmente fui pródigo em palavras locais (não prescindindo de palavras como cuchilleros, milonga, tapia e outras) e escrevi assim aqueles esquecíveis e esquecidos livros. Há quase um ano escrevi uma história intitulada $A$ morte e a bússola, que é uma espécie de pesadelo, um pesadelo em que figuram elementos de Buenos Aires deformados pelo horror do pesadelo; na história penso no Paseo Colón e o chamo de Rue de Toulon, penso nas quintas de Adrogué e as chamo de Triste-le-Roy. Publicada esta história, meus amigos me disseram que finalmente haviam encontrado no que eu escrevia o sabor dos arredores de Buenos Aires. Precisamente porque eu não me havia proposto encontrar esse sabor, porque me havia abandonado ao sonho, pude lograr, ao cabo de tantos anos, o que antes buscara em vão. (BORGES, 1986, p.121)
\end{abstract}

Borges demonstra que, na sua percepção, somente quando o escritor trata dos temas universais é que consegue escrever verdadeiramente sobre sua terra e suas tradições culturais. Segundo ele, os argentinos não estariam desvinculados do seu passado europeu, e podem manejar os temas trazidos do antigo continente de forma livre, enriquecendo-os.

Ao concluir o ensaio, numa visão semelhante à apresentada por Bachelard em relação ao devaneio criador, Borges afirma: "se nos abandonamos a esse sonho voluntário que se chama criação artística, seremos argentinos e seremos, também, bons ou toleráveis escritores" (BORGES, 1986, p.126).

A busca por uma literatura capaz de representar a identidade nacional é uma atitude presente nas obras de escritores latino-americanos desde o período romântico. De um lado, há em muitos escritores a necessidade de se encontrar uma linguagem particular, um estilo ou um gênero que seja adequado a uma definição do nacional, que possibilite uma diferenciação do modelo hegemônico europeu. 
De outro lado, há a tentativa de se inserir no modelo europeu, pois a partir de modelos e referências similares àquelas já utilizadas, o escritor latino-americano teria a possibilidade de experimentar uma harmonia com a literatura produzida no antigo continente.

Ambas as visões têm como foco o objetivo de fazer com que a literatura produzida na América Latina possa ser lida, valorizada e reconhecida em seu país de origem e em outros países, suplantando as restrições geográficas e econômicas que lhe impõem um natural isolamento.

Este objetivo de criar uma obra de arte que seja vista pelo mundo e possa ser considerada universal estaria alinhado ao conceito que Siskind (2016) denominou de "desejo cosmopolita", o sentimento do escritor latino-americano de se colocar em igualdade com os escritores das principais literaturas mundiais.

\begin{abstract}
el cosmopolitismo fue un entramado discursivo estratégico, calculado, que intentaba negociar un lugar de enunciación a la vez particular y universal, en el contexto de la hegemonía global de la cultura moderna tratando de corregirla y redirigirla, en franca oposición a modalidades locales de esa hegemonía particularista, nacionalista, hispanófila o etnocéntrica. Estas autorrepresentaciones cosmopolitas dependían de una dislocación del orden simbólico que contenía y confinaba al intelectual latinoamericano y que estaba constituido por la experiencia traumática y paralizante de una marginalidad opresiva que debía ser reprimida para embarcarse en este proceso de subjetivación cosmopolita. (SISKIND, 2016, p.41)
\end{abstract}

A necessidade de lutar contra a marginalidade artística a qual é submetido leva o escritor latino-americano a buscar formas de se estabelecer no cenário hegemônico. É neste embate que o escritor irá desenvolver um discurso que seja ao mesmo tempo particular e universal e que surja a partir de uma "subjetivação cosmopolita". Uma visão que se demonstra próxima da proposta de Borges, em que, a partir do elemento universal, o local emerge, particularizando a obra.

Em sua obra, Borges cria e recria a partir de referências literárias e filosóficas universais, buscando exatamente aquilo que propôs em seu ensaio, a possibilidade de fazer emergir o aspecto argentino de forma natural, enriquecendo o elemento originário europeu.

Segundo Sarlo (2007), Borges trabalhava "en las orillas", ou nas margens, e a partir desta condição, vai ao centro buscar as bases para uma escritura original, uma intertextualidade criadora, criativa, libertadora.

Colocado en los límites (entre géneros literarios, entre lenguas, entre culturas), Borges es el escritor de "las orillas", un marginal en el centro, un cosmopolita en los márgenes; [...]; alguien que, paradójicamente, construye su originalidad en la afirmación de la cita, de la copia, de la reescritura de textos ajenos, porque piensa, desde un principio, en la fundación de la escritura desde la lectura, y desconfía, 
desde un principio, de la posibilidad de representación literaria de lo real. (SARLO, 2007, p.9)

Cecília Meireles, durante sua vida, dedicou grande atenção a temas ligados ao folclore brasileiro, tendo publicado diversos estudos nesta área e realizado, inclusive, trabalhos nas artes plásticas sobre elementos da cultura popular. Apesar disso, sua obra é marcada por uma contemplação permanente sobre o mundo e sobre o tempo, e uma confrontação da realidade material efêmera, com algo perene, imutável.

As características da obra da poeta não costumam apresentar elementos relacionados diretamente a uma determinada cor local, ou a regionalismos. Conforme Gouvêa (2008), a escrita da poeta, a partir da subjetividade, introduz uma obra "tão vasta quanto discreta" em que estão presentes elementos de diversas tradições:

outra aporia [...] refere-se à erudição [...] na escrita da autora, tão vasta quanto discreta, à recorrente reminiscência de tradições poéticas e filosóficas, universais e da língua portuguesa, desde as mais remotas até algumas das práxis contemporâneas - as quais subjazem amalgamadas em seu tecido poético, de modo quase sempre velado, sob a aparência de simplicidade ou mesmo singeleza. (GOUVÊA, 2008, p.16)

Há, portanto, na obra de Cecília Meireles, alusões a diversas referências do conhecimento humano, tanto no que se refere às tradições ligadas à origem da poeta, como a outras consideradas universais. À diferença de Borges, não é comum a referência explícita a autores ou obras filosóficas e poéticas nos textos da poeta brasileira, que seria o que Gouvêa (2008) considera que está amalgamado no "tecido poético" de forma oculta, e com aparente simplicidade.

\subsection{Não adesão a movimentos artísticos}

Cecília Meireles publicou seu primeiro livro Espectros em 1919, e na década seguinte irá consolidar sua condição de escritora, publicando novos livros e participando como colaboradora da revista Festa, uma publicação cujo grupo responsável procurava retomar valores do Simbolismo, utilizando elementos espiritualistas e buscando estabelecer uma oposição à visão cientificista e racional.

Naquele período, surgiu no Brasil o Modernismo, um movimento artístico de ruptura com os movimentos que o antecederam. Tendo como influência vanguardas europeias - como o Surrealismo e o Cubismo -, o Modernismo brasileiro foi marcado pela tentativa de se criar 
uma estética artística genuinamente nacional, em que a identidade brasileira surgisse a partir da utilização de elementos culturais populares, inclusive pelo uso da linguagem coloquial.

A poeta Cecília Meireles não acompanhará o movimento modernista brasileiro - ao menos o original, marcado pela ruptura -, e construirá uma obra que, apesar da influência simbolista inicial, apresentará características próprias, particulares, em que o aspecto subjetivo e metafísico ganha preponderância.

Conforme GOUVEIA (2002, p.17) “Cecília distancia-se de escolas, sendo o seu discurso, por vezes antitético, paradoxal, predominantemente espiritualizante e intuitivo, um meio de buscar a intemporalidade da condição humana e de traduzir um sereno desespero perante o Destino".

O movimento modernista brasileiro não guarda relação direta com o movimento modernista de origem hispânica, surgido no final do século XIX. O Modernismo no mundo hispânico apresenta como importante aspecto o fato de ter sido um movimento surgido no continente americano, e que, posteriormente, se expandiu para a Espanha, invertendo assim o sentido da relação cultural usual entre os continentes.

Diferentemente do movimento brasileiro, o Modernismo hispânico apresentava, em seu primeiro momento, influência direta de escolas literárias de origem francesa como o Simbolismo e o Parnasianismo, fazendo com que questões como forma, ritmo e musicalidade fossem essenciais na poesia produzida por seus autores. Posteriormente, num segundo momento, o movimento hispânico passou a perseguir temas genuinamente americanos, no que, então, pode se considerar que guarde certa relação com o posterior movimento brasileiro.

\footnotetext{
Dentro del modernismo pueden apreciarse dos etapas: en la primera, el culto preciosista de la forma favorece el desarrollo de una voluntad de estilo que culmina en refinamiento artificioso y en inevitable amaneramiento. Se imponen los símbolos elegantes, como el cisne, el pavo real, el lis; se generalizan los temas desentrañados de civilizaciones exóticas o de épocas pretéritas; se hacen malabarismos con los colores y las gemas y, en general, con todo lo que hiera los sentidos; y la expresión literaria parecer reducirse a un mero juego de ingenio que sólo persigue la originalidad y aristocracia de la forma. [...]

En la segunda etapa se realiza un proceso inverso, dentro del cual, a la vez que el lirismo personal alcanza manifestaciones intensas ante el eterno misterio de la vida y de la muerte, el ansia de lograr una expresión artística cuyo sentido fuera genuinamente americano es lo que prevalece. Captar la vida y el ambiente de los pueblos de América, traducir sus inquietudes, sus ideales y sus esperanzas, a eso tendió el modernismo en su etapa final, sin abdicar por ello de su rasgo característico principal: trabajar el lenguaje con arte. (UREÑA, 1978, p.33-34)
}

Principal nome do Modernismo hispânico, o nicaraguense Rubén Darío, conforme SISKIND (2016, p.160), considerava que o movimento atendia a um desejo de entrar em 
contato com o mundo todo. Outro nome importante do movimento, o cubano José Martí normalmente considerado uma espécie de fundador de uma identidade latino-americana -, defendia a existência de uma literatura mundial, e, ainda segundo SISKIND (2016, p.166), essa aparente contradição entre pulsões particularistas e universalistas seriam a base do próprio movimento modernista.

De modo semelhante ao Brasil, a Argentina também viveu um movimento artístico vanguardista na década de 1920, denominado Ultraísmo que rompeu com modelos anteriores, especialmente com o Modernismo hispânico. Movimento artístico eminentemente poético, o Ultraísmo tinha em suas características a ênfase na utilização da metáfora, a retirada dos adornos da adjetivação da linguagem, a abolição da rima, dentre outras.

Conforme apresentado no capítulo anterior, Jorge Luis Borges participou do movimento ultraísta desde o início, tendo sido ele, inclusive, o autor do artigo na revista Nosotros, em 1921, que apresentava os objetivos do movimento e indicava as características da poesia produzida por seus autores. No mesmo artigo, Borges fez críticas ao movimento modernista:

Esto lo afirmo, pese a la numerosidad de monederos falsos del arte que nos imponen aún las oxidadas figuras mitológicas y los desdibujados y lejanos epítetos que prodigara Darío en muchos de sus poemas. La belleza rubeniana es ya una cosa madurada y colmada, semejante a la belleza de un lienzo antiguo, cumplida y eficaz en la limitación de sus métodos y en nuestra aquiescencia al dejarnos herir por sus previstos recursos; pero por eso mismo, es una cosa acabada, concluida, anonadada. Ya sabemos que manejando palabras crepusculares, apuntaciones de colores y evocaciones versallescas o helénicas, se logran determinados efectos, y es porfía desatinada e inútil seguir haciendo eternamente la prueba. (BORGES, 2011c, p.81)

Ocorre que, pouco tempo depois, Borges se afasta do Ultraísmo, tornando-se, posteriormente, crítico do movimento.

Borges comprende la inoperancia de la metáfora vanguardista en su lírica y necesita
buscar un cauce más personal, que posteriormente hallará por el camino del mito y
del símbolo. De ello derivan sus constantes reflexiones y sus cambios de puntos de
vista, los que no obstante, siempre se apoyan en la conciencia de una tradición
literaria, en un orden eterno. [...] Borges no se ubica ya en la posición
revolucionaria del escritor vanguardista, sino desde una perspectiva más amplia que
incluye distintos puntos de vista, y que le permite ver los movimientos literarios
como síntesis y como una apertura en la historia de la literatura. (GERTEL, 1976,
p.99-100)

Finalmente, nas entrevistas já citadas, Borges apresentou um argumento favorável ao Modernismo hispânico, e, em especial, à importância de Rubén Darío na literatura de língua espanhola, depois de séculos de "decadência": 
Eu penso que tudo o que foi feito depois não poderia ter sido feito sem o modernismo, o que, em certos casos, seria, bom, injusto culpar o modernismo pelo ultraísmo, que foi uma bobagem, ou pelo criacionismo. Mas, no entanto, essas coisas não teriam sido feitas sem Darío. [...] porque realmente eu penso que, a partir do Século de Ouro, e talvez incluindo o Século de Ouro, decai a poesia espanhola. Acredito que o Conceptismo, o Culteranismo, sejam formas de decadência.[...] E depois temos o século XVIII muito pobre, o século XIX também, e então vem Darío e tudo se renova. E isso se renova na América e depois chega à Espanha, e inspira grandes poetas como os irmãos Machado, e como Juan Ramón Jiménez. (FERRARI, 2009b, p.126)

Em função de tudo que foi acima exposto, pode-se perceber, portanto, que ambos os escritores, Cecília Meireles e Jorge Luis Borges, guardam em comum a característica de terem convivido, à mesma época, em seus respectivos países, com movimentos vanguardistas que apresentavam características de rompimento com movimentos artísticos anteriores. E os dois autores não seguem estes movimentos, ao contrário, irão trilhar um caminho independente desses movimentos, seguindo numa perspectiva mais intimista e particular.

\subsection{Aproximação com pensamento oriental}

Um outro aspecto comum entre os escritores é a rejeição de ambos ao nacionalismo. Borges, que se referia a si mesmo como "um inofensivo anarquista", considerava o nacionalismo como um "dos máximos males desta época [...] do planeta dividido em países, e esses países possuidores de fronteiras, de lealdades, de preconceitos...” (FERRARI, 2009b, p.82). Por seu turno, a poeta Cecília Meireles

\footnotetext{
defendeu a ideia da fraternidade mundial e de uma irmandade que não fosse nacional, isto é, limitada pelos símbolos e pelo sentimento de pertencimento típicos das Nações-Estado. Em seus artigos, pregava a abolição total das velhas instituições, em prol do renascimento de uma sociedade menos apaixonada pelos símbolos de uma pátria construída na base da exclusão, da desvalorização de seus cidadãos e cidadãs e das guerras. (LAMEGO, 2001, p.219)
}

Em um ensaio publicado no ano de 1961, Jorge Luis Borges fez uma apreciação crítica de textos do escritor indiano Rabindranath Tagore, vencedor do prêmio Nobel de Literatura de 1913. Os textos analisados foram apresentados numa conferência sobre o tema do nacionalismo realizada em São Francisco, no ano de 1917, ao final da Primeira Guerra Mundial.

Por vezes, Borges fez restrições públicas à poesia de Tagore, no entanto, neste ensaio, demonstra concordar com a tese apresentada pelo poeta indiano, de que a ideia de nação seria a raiz de dois males: o nacionalismo e o imperialismo. Ao final do ensaio, Borges acrescenta 
que Tagore reuniria em si as culturas ocidental e oriental e afirma que "en cada página de este libro conviven la afirmación asiática de las ilimitadas posibilidades del alma" (BORGES, 2011, p.113).

A aproximação de Borges com as ideias orientais de "ilimitadas posibilidades del alma" ocorrerá também com Cecília Meireles, que, desde cedo teria demonstrado interesse pela Índia, sua cultura, religião e literatura. Segundo consta em uma de suas crônicas de viagem, intitulada "Transparência de Calcutá", o interesse pela Índia teria iniciado "por ocasião da atribuição do prêmio Nobel a Tagore - em 1913, portanto, quando contava onze ou doze anos" (GOUVÊA, 2008, p.38).

No seu primeiro livro, Espectros, a poeta incluiu um poema que faz referência direta à Índia, de título Brâmane, que apresenta um asceta desta casta, cujos componentes são instruídos a "praticarem a caridade e a renúncia ascética, a não acumular bens e a purificar os desejos e controlar os sentidos sensoriais" (OLIVEIRA; SINGH, 2014, p.119).

Em 1923, Cecília Meireles publicou um poema dedicado ao poeta indiano Rabindranath Tagore, que realizaria uma visita à América do Sul no ano seguinte. A admiração da poeta por Tagore e por Mahatma Gandhi, veio ampliar seu interesse pela Índia, país que viria a conhecer apenas no ano de 1953. Conforme Dilip Loundo (2007, p.153-154), a poeta percebia que, em Tagore, Deus seria uma "experiência mística e transcendental"; enquanto que, em Gandhi, seria "a Verdade, aqui e agora"; posturas distintas, mas fundamentais para a existência da civilização indiana.

Ainda de acordo com Loundo (2007), os primeiros livros de Cecília Meireles, apresentam poemas que, além das características parnasianas e neo-simbolistas, demonstrariam a influência do "lirismo místico" de Tagore. Posteriormente, a partir da publicação de Viagem, a poeta passaria à percepção de que a "ascese espiritual" só é realizável, caso se busque o "conhecimento do mundo", e não evadir-se dele. Surge então, na obra da poeta, o que Dilip Loundo denomina "lirismo filosófico", que será marcado pela presença da "filosofia indiana", um novo caminho de conhecimento que

\footnotetext{
Consiste num método de desprendimento de todos os objetos empíricos [...] que, em lugar de evasão, significa proximidade epistemológica e envolvimento compassivo como os mesmos; e uma resolução metafísica consequente que, ao invés de um reino ontológico transcendente a este mundo, se instaura enquanto fundação [...]. Em suma, o lirismo maduro de Cecília Meireles reflete uma determinação qualificada de conhecer a totalidade de um mundo que se faz presente como ponto inicial e como destinação final (diferenciada) de sua jornada filosófica. Daí o caráter positivo e antiniilista da lírica ceciliana, marcada pela diversidade de motivos, pelo elogio cromático das formas mundanas, pela contemplação totalizante que a tudo abarca [...] (LOUNDO, 2007, p.133)
} 
A obra de Cecília Meireles passa então a apresentar esta tentativa de aproximação do todo, do universal, a partir de um desapego material em prol de uma purificação espiritual, enquanto busca no múltiplo, na diversidade, a unidade do divino. Uma percepção que perpassa ainda a experiência do momento instantâneo, que a poeta expõe nos versos de Solombra: "Ir falando contigo, e não ver mundo ou gente. E nem sequer te ver - mas ver eterno o instante" (MEIRELES, 2001, p.1265). O eterno instante a suspender o tempo, a levar cada momento ao patamar da eternidade, da comunhão com a unidade.

No livro Poemas escritos na Índia, alguns versos demonstram alguns dos aspectos culturais indianos acima relacionados. No poema Pobreza, a ascese, o desapego material são apresentados na figura de um "velho", que é inicialmente retratado quase como uma estátua, mas que estava "vivo, existente", que "suplicava", "e tinha o mundo em seus olhos de opala"; a presença do todo no indivíduo. O indivíduo que é criatura, mas também divino, e que "ao pedir, abençoava”. E a importância da sua vida desprovida de bens é retratada nos versos finais: "Tão pobre que parecia divino".

O poema Manhã , do mesmo livro citado no último parágrafo, apresenta uma sequência de elementos, fragmentos que, agregados, vão formando o todo, que no poema é a manhã retratada. São então citados: "o sol que chegou cedo", "o som” das conversas dos lavadeiros, "a voz das águas", "a minha vida", "a minha alma", "uma saudade", todos num processo de integração da paisagem, do sentimento da poeta, na eternização do instante a-histórico.

\section{Manhã}

Há o Sol que chegou cedo à montanha ventosa

e a alva roupa translúcida que os lavadeiros abrem no ar.

Há o som de suas conversas, matinal, risonho, límpido.

Há a crespa voz das águas com mil anéis para mil dedos.

Há a minha vida sob cortinados,

e a sensação da fresca manhã lá fora.

Há minha alma cheia de amor, num mundo que não me pertence.

Há uma saudade secular de infâncias, ternura, humanidade.

Há um desejo de aqui ficar para sempre, sob os cortinados de tule, vendo o mosquito escrever seu zumbido com finos traços, ouvindo lá fora os lavadeiros, com suas cordas, suas historias, sentindo o vento levantar para o céu nuvens de roupas...

Unidade, alegria, festa, inocência do mundo.

Manhã clara. 


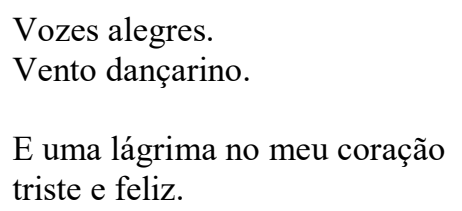

(MEIRELES, 2001, p.1018).

Um mosaico que é sintetizado no verso "Unidade, alegria, festa, inocência do mundo", que representa a unidade em sintonia. $\mathrm{O}$ tudo que leva o sujeito poético às lagrimas, mas que se confessa "triste e feliz", por perceber neste momento o encontro com a eternidade que tanto almeja.

A aproximação de Cecília Meireles com a cultura e o pensamento oriental, que desde a juventude a aproximou da Índia, na maturidade abrangeu outras regiões do Oriente. Em seu trabalho, a poeta realizou traduções de poetas de Israel e chineses como Li Po e Du Fu e, também "se referiria na obra em prosa, além de a pensadores como Buda, Confúcio e Lao Tsé, [...] a múltiplos escritores como os persas Gazzali, Kayam [...], o árabe Haji Abdul elYez [...], os japoneses Kikaku e o "divino Bachô”” (GOUVÊA, 2008, p.38).

Sobre o poeta Bachô (ou Matsuo Bashō), Cecília Meireles escreveu uma crônica, publicada no livro Escolha o Seu Sonho, em que faz comentários sobre a forma poética do hái-kái, do qual o poeta japonês foi um dos mestres. Ao final do texto, a poeta faz uma observação que denota o estado de espírito que experimentava em relação à sua época:

Este pequeno exemplo de compaixão, conservado num breve poema japonês de trezentos anos, emociona e confunde estes nossos grandiosos tempos bárbaros. Mas sua luz não se apaga, e até se vê melhor - porque vastas e assustadoras são as trevas dos nossos dias. (MEIRELES, 1996, p.12)

O trecho acima demonstra a existência de um sentimento de não-conformidade, de estranhamento em relação ao mundo em que vive. A completude, a eternidade do instante, o desapego, a busca pela unidade que conhecera no mundo indiano e que fora motivo de inspiração na vida e no trabalho, não se alinha com o mundo em que vive, resgatando o sentimento expresso pela poeta sobre seu defeito: "uma certa ausência do mundo".

A melancolia e a sensação de estranhamento frente a uma realidade que por um lado é sem sentido, e por outro aterrorizante, serão sentimentos que acompanharão a trajetória da poeta desde sempre. Os ideais de vida, de sociedade e de mundo parecem se afastar de tal maneira que o sonho surge como possibilidade de se afastar de uma realidade que se afigura sem solução. Em artigo sobre o livro Solombra, João Adolfo Hansen apresenta uma análise do sentimento experimentado pelo sujeito poético: 


\begin{abstract}
A afirmação do sonho como atividade imaginária que transforma restos acompanhase da dupla negação temporal do presente e do passado. "Nada escuto / nada alcanço", diz o eu, referindo-se à sua total fidelidade ao objeto, fidelidade que o faz isento e ausente do presente. E "nada escuto / nada alcanço", diz, referindo-se também ao perdido. Aqui, o eu, melancólico, sombrio, elegíaco, solitário, faz da negação do presente e do passado pela imaginação que os inventa o princípio de sua autonomia: "Quem me vê não me vê, que estou fora do mundo". A autonomia do eu afirma a transcendência precária da sua arte: a autonomia é a negação de um mundo, este, nosso, aqui e agora, que não presta, e do passado, que é "Lá, constante presença em memória guardada", segundo o eu, que também afirma "percebo a tua essência e não sei nem teu nome". (HANSEN, 2007, p.44)
\end{abstract}

A necessidade de estar fora do mundo, a negação do presente e do passado, a remissão a um instante que somente existe na memória, demonstram o desencanto perante a inutilidade de ser, perante uma realidade da qual não se deseja fazer parte, da qual se sente fora. Nesta circunstância, a busca pelo transcendental será possível por intermédio do sonho que surge como possibilidade de fuga, uma tentativa de obter, em um outro mundo, as respostas que não serão possíveis na realidade vigente.

\title{
4.5 Relação com ideias de Schopenhauer
}

Jorge Luis Borges, na entrevista anteriormente citada, relata sua aproximação com a cultura e o pensamento orientais após ler, durante sua juventude, obras de Arthur Schopenhauer que faziam referência ao budismo. A partir daí, a leitura de livros relacionados ao filósofo alemão, ampliaram seu interesse pelo budismo e pelo hinduísmo, especialmente:

Por isso eu acredito que tudo foi pensado no Oriente. [...] De modo que eu tenho um enorme respeito e um enorme amor pela filosofia da Índia especialmente, e pela da China, porque se eu reconheci tantas coisas estudando essas filosofias, com algum conhecimento da filosofia ocidental, isso significa que, sem dúvida, há muitas outras coisas que eu não reconheci porque ainda não se manifestaram no Ocidente, mas que se manifestarão. Por isso, essas filosofias do Oriente são, de fato, inesgotáveis. (FERRARI, 2009a, p.226-227)

Schopenhauer utiliza o que chama de "sabedoria milenar dos indianos" para construir sua visão do mundo como representação. Em uma citação dos Vedas, uma das coletâneas de textos sagrados do hinduísmo, o filósofo cita $m \bar{a} y \bar{a}$, que seria "o véu da ilusão que envolve os olhos dos mortais, deixando-lhes ver um mundo do qual não se pode falar que é, nem que não é, pois assemelha-se ao sonho" (SCHOPENHAUER, 2011, p.9).

A renúncia ascética, elemento presente no hinduísmo, é considerado por Schopenhauer como uma forma de negação da vontade, na busca pelo auto-conhecimento. A ascese deve servir "como mortificação contínua da vontade, com o que a satisfação dos desejos, as 
doçuras da vida, não mais estimulam a vontade, contra a qual o autoconhecimento provocou repugnância” (SCHOPENHAUER, 2011, p.443).

Apesar disso, ao final do seu texto, Schopenhauer estabelece uma crítica à visão de evolução existente no hinduísmo e no budismo, contrapondo uma visão niilista da existência, sem que haja um prêmio a posteriori.

Dessa forma, pela consideração da vida e conduta dos santos [...] havemos de dissipar a lúgubre impressão daquele nada, que como o último fim paira atrás de toda virtude e santidade, e que tememos como as crianças temem a escuridão; melhor isso, em vez de nos esquivarmos do tema, como o fazem os hindus, através de mitos e palavras vazias de sentido, como "reabsorção em Brahman", ou "Nirvana" dos buddhistas. Antes, reconhecemos francamente: para todos aqueles que ainda estão cheios de vontade, o que resta após a completa supressão da vontade é, certamente, o nada. (SCHOPENHAUER, 2011, p.476-477)

A poeta Cecília Meireles demonstra em vários de seus textos, especialmente naqueles que tratam do elemento do sonho, uma espécie de desencanto em relação a esta possibilidade. Se por um lado, as doutrinas orientais lhe parecem trazer a esperança numa unidade no absoluto, numa condição de evolução, por outro lado, a perspectiva de uma espécie de "nada" schopenhaueriano, torna-se de fato assustadora, e surge o temor como o da criança em relação à escuridão. O sonho seria então para a poeta, uma forma de fuga da realidade presente, da perspectiva de outros planos, onde haja, como proposto pelos orientais, uma outra possibilidade, aperfeiçoada, onde o eterno instante seja uma espécie de nirvana. Como pode ser percebido no poema Sonho de sepulcro, também presente na coletânea Sonhos:

Sonho de sepulcro

Eu mesma vejo o meu sepulcro.

Vejo-o e toco seus relevos.

Eu mesma estou deitada, e sou mármore feliz,

belo mármore dourado, em posição de eterno sonho.

Eu mesma vejo o meu sepulcro.

fica perto do mar, fica debaixo das árvores, um amigo o mandou de longe, e andamos em redor dele, e eu me sinto parecida com uma que fui um dia.

E há um ramo de flores secas no meu sepulcro, e eu mesma retiro do meu peito as flores secas.

Eu mesma ajudo minha escultura a virar-se para o outro lado.

Pois até no sepulcro é preciso haver flores novas.

E descansar de um sonho noutro.

(MEIRELES, 2001, p.1316) 
No poema, pode-se perceber como o sujeito poético encara a morte como um refúgio, cujo sepulcro além de apresentar características de beleza é também um lugar aprazível de aconchego: "belo mármore dourado", "fica perto do mar, fica debaixo das árvores". No sepulcro, o sujeito poético declara "me sinto parecida com uma que fui um dia", uma forma de resgate do eterno instante do passado.

Na primeira estrofe, há a expressão de que no sepulcro está deitada "em posição de eterno sonho", uma indicação de que a morte não seria apenas um sono eterno, como normalmente apregoado pela voz corrente, mas sim um sonho eterno, onde o sepulcro se transforma numa morada, que deve ser cuidada como aquelas que se têm em vida.

No último verso, há a indicação de que no sepulcro se vai "descansar de um sonho noutro", o que reafirma a visão de que a vida também seria um sonho. No entanto, no poema pode-se perceber o sentimento de encontrar, na morte, um sonho do qual se refugie do sonho de viver. A esperança num eterno instante que resgate do passado perdido e que traga apenas a serenidade de ser "mármore feliz".

Jorge Luis Borges não aparenta o mesmo desencanto de Cecília Meireles, conhecedor e admirador do pensamento oriental é bastante alinhado com a percepção proposta por Schopenhauer, em que o pessimismo dá lugar a certa serenidade em relação à existência, e que encontra na arte um lenitivo frente ao nada.

Em Borges, a percepção da criação como uma espécie de sonho divino, em que o absoluto está presente em tudo, faz com que o homem seja ele mesmo um sonho, um simulacro de realidade. Neste aspecto, o sonho ou o devaneio faz do homem também um criador, alguém que estabelece um novo plano para o universo de infinitos planos e repetições.

\footnotetext{
A través del sueño, de la imaginación, de la fantasía, de la magia, de los artificios y del mito, el ser humano consigue superar y trascender este mundo, en el arte y la literatura. La filosofía no es menos fantástica que el arte. Borges convierte así al ser humano en un acuñador de ficciones y un creador de mitos. (YOUNES, 1996, p.90)
}

O conto El Zahir, incluído no livro El Aleph (1949), é narrado em primeira pessoa, por um personagem cujo nome é o mesmo do autor: Borges. No conto, é relatada a história de uma moeda, o Zahir, que chega às mãos do personagem-narrador em um bar ao qual havia ido após sair do enterro de uma mulher de quem estava "enamorado". A partir de então, o narrador relata como aquela moeda pode representar ao mesmo tempo várias outras coisas e ter diversos significados distintos tornando-se um pensamento fixo que o conduzirá à loucura. 
No conto, vários trechos permitem ilustrar alguns dos pensamentos do escritor. Logo no início o narrador cita que a mulher morta que era toda "ortodoxa" e seguidora das modas "buscaba lo absoluto, como Flaubert, pero lo absoluto en lo momentâneo. Su vida era ejemplar y, sin embargo, la roía sin trégua uma desesperación interior." (BORGES, 2011, p.266). Enquanto Flaubert buscou o absoluto em suas obras, na arte, a mulher buscou no cotidiano, na saciação da vontade, sem sucesso, chegando ao desespero.

Interessante observar a busca do absoluto no momentâneo, no instante; algo que, à primeira vista, poderia levar à associação com o "eterno instante" de Cecília Meireles, mas que ao observarmos a característica da personagem, podemos perceber que na personagem há a exaltação da vontade, enquanto nos poemas de Cecília Meireles há uma tentativa de busca do divino oculto na representação.

Adiante, no mesmo conto, o narrador comenta que estava compondo um conto fantástico. O narrador dentro do conto, criando outro conto em que há outro narrador, e que este narrador "es un asceta que ha renunciado al trato de los hombres y vive en una suerte de páramo" (BORGES, 2011a, p.268). Neste conto, o narrador acaba se revelando uma serpente de nome Fafnir, ser da mitologia nórdica, apresentado na obra $O$ Anel dos Nibelungos do compositor alemão Richard Wagner. A obra de Wagner foi muito influenciada pelo pensamento de Schopenhauer, uma referência que ilustra a presença do filósofo na obra do narrador do conto.

O narrador, posteriormente, indica que encontrara um livro que reunia documentos sobre a superstição do Zahir. Na cultura islâmica, ele seria um dos nomes de Deus, e, entre tantas outras referências, se referiria a uma "especie de tigre infinito", que, em uma pintura de um "faquir musulmán", era feito de outros tigres circundado por mares, montanhas e exércitos todos semelhantes a tigres. A ideia de planos e repetições infinitos presentes nos seres.

Ao final do conto, o narrador reconhece que a ideia fixa no Zahir o levará à loucura, mas não demonstra desespero com a situação, ao contrário, aparenta total serenidade, chamando de "falacia" se referir a esta situação como terrível. $\mathrm{Na}$ página final, várias observações do narrador fazem referência à visão de mundo do escritor, e, especialmente, à relação com as ideias de Schopenhauer:

Antes yo me figuraba el anverso y después el reverso; ahora, veo simultáneamente los dos. [...] el mundo visible se da entero en cada representación, de igual manera que la voluntad, según Schopenhauer, se da entera en cada sujeto. Los cabalistas entendieron que el hombre es un microcosmo, un simbólico espejo del universo [...] Según la doctrina idealista, los verbos vivir y soñar son rigurosamente sinónimos; de miles de apariencias pasaré a una; de un sueño muy complejo a un sueño muy 
simple. [...] Quizá yo acabe por gastar el Zahir a fuerza de pensarlo y de repensarlo; quizá detrás de la moneda esté Dios. (BORGES, 2011, p.273)

No trecho o narrador faz referência à ideia do mundo como vontade e representação de Schopenhauer, mas agrega a ela a visão cabalista de ver o homem como um "microcosmo", além de apresentar a percepção dos idealistas de que viver e sonhar seriam a mesma coisa. Ao ser absorvido completamente pela ideia fixa no Zahir, o narrador pensa que talvez tenha chegado ao absoluto, à essência do sonho mais simples, ao sonho original divino.

Em sua obra de ensaios chamada Outras inquisições, Borges incluiu um capítulo em que discute a proposta de existência de tempos infinitos do filosófo irlandês J. W. Dunne. Apesar de não concordar plenamente com as ideias do autor sobre a existência de tempos subjacentes, Borges se demonstra impressionado pela visão de Dunne de que o sonho seria a comprovação de que a eternidade já nos pertenceria, que o eterno não seria necessariamente uma exclusividade do divino, conforme proposto pelos teólogos.

Dunne, surpreendentemente, supõe que a eternidade já nos pertence e que isso é
corroborado pelos sonhos de cada noite. Nestes, segundo ele, confluem o passado
imediato e o imediato porvir. Na vigília percorremos o tempo sucessivo a uma
velocidade uniforme, no sonho abarcamos uma área que pode ser vastíssima. Sonhar
é coordenar os vislumbres dessa contemplação e com eles urdir uma história, ou
uma série de histórias. [...] (Schopenhauer escreveu que a vida e os sonhos são
folhas de um mesmo livro e que lê-las em ordem é viver; folheá-las, sonhar.)
Dunne garante que na morte aprenderemos o feliz manejo da eternidade.
Recuperaremos todos os instantes de nossa vida e os combinaremos como bem
entendermos. Deus, e nossos amigos, e Shakespeare colaborarão conosco.
(BORGES, 1999, p.25)

Neste trecho, é possível perceber que Borges compartilha a ideia de que o sonho seria o elemento que possibilita este encontro com a eternidade. A referência a Shakespeare nos remete naturalmente ao conto anteriormente apresentado Everything and Nothing, e à ideia de que o dramaturgo inglês era também uma espécie de deus ao criar seus personagens.

O sonho noturno seria, portanto, a possibilidade da experiência da eternidade em vida, a confluência de passado e futuro num só instante, uma equiparação com o divino antes da morte. O devaneio permite, de forma semelhante, a criação de outras existências na ficção, que poderão ganhar vida e eternidade, a partir do imaginário do poeta. A busca por esta eternidade será parte do trabalho do poeta, onde importará encontrar o absoluto no efêmero, o eterno no instante. Neste sentido irá caminhar a poesia de Cecília, a busca pelo eterno instante: 
Cecília engloba todas as ações possíveis em todos os espaços e tempos possíveis. [...] Encara o instante poético de forma unidimensional, como num [...] desvinculamento com o mundo. Este instante assim definido, não só pode ser considerado a ponte entre o terreno e o divino, como também releva a intuição do infinito num mundo de coisas e sonhos. Cecília elege o instante poético como meio de aprender a ver de forma nova o mundo. $O$ instante é criação. A poesia parte da emoção do instante, é instante privilegiado e eterno, interioridade e êxtase. (GOUVEIA, 2002, p.142)

Como visto no poema Em sonho anunciam a minha morte, em que a realidade é vista com desilusão, num cenário em que o absoluto parece distante ou inexistente, o sonho surge como alternativa para tentar atingir o eterno. A incompletude e o desencanto vividos na realidade fazem com que a morte pareça já estar presente, fazendo com que a esperança possível esteja no sonho, como nos versos de Aqui estou nos vales da terra: "Vivo do que sonho, e tudo mais parece morte".

Não há registro que indique algum encontro de Cecília Meireles com Jorge Luis Borges, nas vezes em que viajaram para os países um do outro. Tampouco não foi possível encontrar alguma referência que indique que os escritores tenham conhecido a obra produzida por cada um. No entanto, a aproximação de Cecília Meireles com o pensamento oriental, especialmente com as tradições hindus e budistas, evidenciadas em crônicas e poesias, foi compartilhada por Borges.

Esta aproximação, possivelmente, tem raiz comum nas ideias propostas por Schopenhauer, de quem Borges foi reconhecidamente leitor, e que também buscou no pensamento oriental parte da inspiração de sua filosofia. De forma semelhante, segundo Gouvêa (2008, p.121) a obra de Cecília Meireles apresentaria um "livre pensamento" em que estão presentes, entre outras filosofias, a de Schopenhauer. Provavelmente produzidas a partir de ideias e inspirações semelhantes, as obras dos escritores demonstram diferenças na forma como percebem o elemento do sonho na realidade, na vida e na morte.

Em Cecília Meireles há uma certa desesperança no sonho que a vida proporciona, e uma expectativa em relação à morte como um sonho onde se alcance um outro estágio, aperfeiçoado, próximo da ideia oriental de nirvana.

Já em Jorge Luis Borges, a realidade da vida é percebida como um sonho criado por um autor, e se vê a si mesmo como um criador de realidades, uma espécie de deus que dá vida a novas realidades e novos personagens, enquanto os imagina durante a vigília.

Estas experiências que são objeto de estudo em diversas áreas, como a Filosofia, podem ser representadas na Literatura, seja em forma de sonho ou devaneio, numa temática recorrente, que, como pudemos perceber, na América do Sul, foi utilizada pelos poetas Cecília 
Meireles e Jorge Luis Borges. Contemporâneos - e quase compatriotas - que se dedicaram ao sonho e suas particularidades, ainda que sob um enfoque diferente. 


\section{CAPÍTULO 5}

\section{CONCLUSÃO}

O elemento onírico, presente no nosso imaginário, estejamos acordados ou dormindo, sempre se coloca como algo fascinante para qualquer ser humano. A possibilidade de fruirmos vivências diferentes daquelas às quais estamos acostumados durante o período da vigília permite que nos afastemos temporariamente da realidade perceptível. Estas experiências que são objeto de estudo em diversas áreas, podem ser representadas na Literatura, seja em forma de sonho ou devaneio.

A princípio, vimos que teorias e conceitos propostos por outras áreas do conhecimento, como a Filosofia, podem ser empregados, subsidiariamente, como forma de possibilitar novos entendimentos do texto poético. Ressaltando-se, contudo, a necessidade exposta de se evitar incorrer no discurso comum de considerar a Filosofia como responsável pelos conceitos, enquanto à Literatura remanesceria o papel de transformar estes conceitos em um discurso apenas belo, mas vazio.

No âmbito da Literatura, a imaginação, presente nos atos de sonhar e de devanear, permite a experiência de outras realidades diferentes daquelas vividas no cotidiano da vigília. O poeta, ao apresentar seu sonho - ou seu devaneio -, e transformá-lo em texto literário, conduz o leitor a outro universo de possibilidades, onde a confrontação com a realidade e sua percepção permite a criação de novas representações do imaginário.

Dentro da cultura ocidental, desde a antiguidade o sonho foi tratado por filósofos, escritores e em textos religiosos, sendo por vezes considerado de origem divina e tendo caráter premonitório. O questionamento da realidade advindo da discussão do fenômeno do sonho no mundo ocidental também sofreu influência das culturas e religiões orientais.

A literatura dos países ibéricos possui em sua história diversas obras de autores relevantes como Cervantes e Camões, que trataram do tema do sonho. Num mesmo período de tempo, durante o século XX, em países vizinhos, cujas civilizações e culturas possuem uma raiz comum na Península Ibérica, os escritores Cecília Meireles e Jorge Luis Borges utilizaram o tema do sonho de forma recorrente, ao produzir uma obra independente em relação a movimentos literários.

A poeta Cecília Meireles tratou da temática do sonho em muitas obras, e, mais especificamente, em uma coletânea de poemas publicados postumamente sob o título Sonhos, composta de quarenta e dois poemas que versam sobre o assunto. Nesta coletânea, os poemas 
abordam o tema do sonho, fazendo com que se estabeleça um olhar crítico em relação à realidade e à forma como ela pode ser confrontada.

Nos poemas Sonhei um sonho, Em sonho anunciam minha morte e Aqui estou nos vales da terra percebe-se a busca por perceber o sonho e o devaneio, como outra realidade em que a vida e a esperança sejam possíveis, e ainda uma tentativa de observar sob outra perspectiva a realidade do período da vigília, que talvez pudesse ser uma outra forma de percepção do mundo real, apresentando semelhanças e dissonâncias em relação ao universo propriamente onírico.

O escritor argentino Jorge Luis Borges expôs, em sua obra, diversos elementos e símbolos, e também diversas referências a teorias filosóficas e pensamentos. O sonho, um dos elementos mais utilizados, serve para estabelecer uma espécie de poética do autor, a partir da qual se torna possível a criação de narrativas e poesias que terão o elemento onírico como parte do argumento para a construção do narrador e do enredo.

No trabalho de análise foram utilizados poemas publicados a partir da década de 1960 e também contos de diversos períodos, mas que têm o sonho como elemento fundamental de sua narrativa: As ruínas circulares e Everything and Nothing; que têm em comum o fato de apresentarem narradores que, em seus sonhos e devaneios, concedem vida a outras realidades e seres.

A confrontação das obras dos dois escritores permitiu a percepção de que, além da possível raiz comum da cultura ibérica, há ainda uma possível influência do pensamento oriental, cuja relativização da realidade e a busca por uma unidade, ou pelo absoluto seriam fatores presentes na forma como o assunto é abordado.

A reconhecida influência de Schopenhauer na obra de Borges torna-se fundamental para que haja um pequeno distanciamento do aspecto mais puramente metafísico do pensamento oriental. Enquanto Cecília Meireles busca o divino e o absoluto na alternativa de realidade possibilitada pelo sonho; em Borges, o próprio ato de sonhar pode levar o ser humano a se equiparar ao divino, ao transformá-lo em criador de realidades.

A análise aqui efetuada poderia ser ampliada em trabalhos posteriores, com a agregação de outras obras dos escritores, assim como a inclusão de outros escritores latinoamericanos, que também se dedicaram ao mesmo tema. Poderia ser interessante estabelecer outras analogias com disciplinas diversas do conhecimento, como a psicologia e a sociologia, de forma a enriquecer a análise e apreciação das obras.

De toda maneira, muito há a ser observado nas obras de Cecília Meireles e de Jorge Luis Borges, não só nesta temática, mas também em outros assuntos, de forma a possibilitar 
um olhar mais amplo sobre estes escritores, cujas obras possuem grande importância no âmbito de suas literaturas nacionais. 


\section{REFERÊNCIAS BIBLIOGRÁFICAS}

ALAZRAKI, Jaime. Borges o el difícil oficio de la intimidad: reflexiones sobre su poesía más reciente. In: Revista Iberoamericana, Pittsburgh, Volumen XLIII, 1977.

Estructura y función de los sueños en los cuentos de Borges. In: Revista Iberoromania, Madrid, Número 3, 1975.

ANDRADE, Carlos Drummond de. Cecília: Imagens para Sempre. In: Correio da Manhã, Rio de Janeiro, 11 nov. 1964.

ANDRADE, Mário de. Literatura modernista argentina III. In: Borges no Brasil. São Paulo: Editora UNESP, 2001.

. Viagem. In: O empalhador de passarinho. Rio de Janeiro: Nova Fronteira, 2012.

ARNÁIZ, Sara Molpeceres. El mito como expresión filosófica. In: Filosofía y Literatura: Diálogo recobrado. Madrid: Editorial Manuscritos, 2013.

ARNAU, Juan. Cosmologías de India. Cidade do México: Fondo de Cultura Económica, 2012.

AZZETTI, Héctor. Itinerario poético de Borges. Buenos Aires: Editorial Biblos, 2011.

BERKELEY, George. Três diálogos entre Hilas e Filonous em oposição aos céticos e ateus. In: Os pensadores: George Berkeley. São Paulo: Nova Cultural, 2005.

BACHELARD, Gaston. A Poética do Devaneio. São Paulo: Martins Fontes, 2009.

BAJTÍN, Mijaíl M. Problemas de la poética de Dostoievski. Cidade do México: Fondo de Cultura Económica, 2003.

BERNUCCI, Leopoldo M. Biografia e visões especulares: Borges e Dante. In: Borges no Brasil. São Paulo: Editora UNESP, 2001.

BLANCHOT, Maurice. O espaço literário. Rio de Janeiro: Rocco, 2011.

BOSI, Alfredo. Em torno da poesia de Cecília Meireles. In: Ensaios sobre Cecília Meireles. São Paulo: Editora Humanitas, 2007.

BORGES, Jorge Luis. Cuentos Completos. Barcelona: Random House Mondadori, 2011a.

Aires, 2001.

Destino e obra de Camões. Buenos Aires: Embaixada de Portugal em Buenos

Discussão. São Paulo: Difusão Editorial, 1986.

El hacedor. Barcelona: Random House Mondadori, 2012.

Libro de sueños. Barcelona: Random House Mondadori, 2013.

. El Nacionalismo y Tagore. In: Redescubriendo a Tagore: con el motivo del 150 aniversario del natalicio del vate indio. Mumbai: Indo-Latin American Cultural Initiative, 2011.

Outras inquisições. São Paulo: Editora Globo, 1999. 
Poesía completa. Barcelona: Random House Mondadori, 2011 b.

Textos recobrados. Barcelona: Random House Mondadori, 2011c.

BRESCIA, Pablo. Modelos y prácticas en el cuento hispanoamericano: Arreola, Borges, Cortázar. Madrid: Iberoamericana, 2011.

BRETON, André. Manifesto do surrealismo. In: Vanguarda europeia e modernismo brasileiro: apresentação dos principais poemas, manifestos, prefácios e conferências vanguardistas, de 1857 a 1972. Petrópolis: Vozes, 2002.

CORTÁZAR, Julio. Un nacimiento, cien años de literatura. Pamplona: Leer-e, 2014.

Obra crítica. Rio de Janeiro: Civilização Brasileira, 1998.

COSTA, Ana Medeiros da. Sonhos. Rio de Janeiro: Jorge Zahar Editor, 2006.

DAMASCENO, Darcy. Cecília Meireles: o mundo contemplado. Rio de Janeiro: Editora Orfeu, 1967.

DE LA BARCA, Pedro Calderón. La vida es sueño. Valencia: Imprenta de Ildefonso Mompié, 1822.

DELEUZE, Giles; GUATTARI, Félix. O que é a filosofía? São Paulo: Editora 34, 2004.

DE MAN, Paul. Un maestro moderno: Jorge Luis Borges. In: Jorge Luis Borges: El escritor y la critica. Madrid: Taurus Ediciones, 1976

DESCARTES, René. Meditações. São Paulo: Editora Nova Cultural, 1996.

FERRARI, Osvaldo. Sobre a filosofia e outros diálogos. São Paulo: Editora Hedra, 2009a.

Sobre os sonhos e outros diálogos. São Paulo: Editora Hedra, 2009b.

FREUD, Sigmund. A Interpretação dos sonhos (I) 1900. Rio de Janeiro: Imago, 2001.

GADAMER, Hans-Georg. De la contribución de la poesia a la búsqueda de la verdad. In: Estética y hermenéutica. Madrid: Editorial Tecnos, 2013.

GAGNEBIN, Jeanne Marie. As formas literárias da Filosofia. In: Filosofia e Literatura. Porto Alegre: Editora da PUC-RS, 2004.

GERTEL, Zunilda. La metafora en la estetica de Borges. In: Jorge Luis Borges: El escritor y la critica. Madrid: Taurus Ediciones, 1976

GOLDSTEIN, Norma Seltzer. O espírito vitorioso: uma proposta de ensino de e pela literatura. In: Ensaios sobre Cecília Meireles. São Paulo: Editora Humanitas, 2007.

1982.

. Literatura comentada: Cecíla Meireles. São Paulo: Abril Educação,

GOUVÊA, Leila V.B. Pensamento e "Lirismo Puro" na poesia de Cecília Meireles. São Paulo: Editora da Universidade de São Paulo, 2008. 
GOUVEIA, Margarida Maia. Cecília Meireles - Uma Poética do Eterno Instante. Lisboa: Imprensa Nacional Casa da Moeda, 2002.

HANSEN, João Adolfo. Solombra, ou a sombra que cai sobre o eu. In: Ensaios sobre Cecília Meireles. São Paulo: Editora Humanitas, 2007.

HEIDEGGER, Martin. Arte y Poesía. Buenos Aires: Fondo de Cultura Económica de Argentina, 1992. ¿Qué es metafísica? Madrid: Alianza Editorial, 2003.

JOST, François. Uma filosofia das letras. In: Literatura Comparada: textos fundadores. Rio de Janeiro: Rocco, 2011.

KHÉDE, Sonia Salomão. A Literatura como arte na contemporaneidade In: Os Contrapontos da Literatura. Petrópolis: Editora Vozes, 1984.

KOHUT, Karl. Sueños en el Renacimiento y en el Barroco hispánicos. De Juan Luis Vives a Sor Juana Inés de la Cruz. In: Los sueños en la cultura iberoamericana (siglos XVI-XVIII). Sevilla: Consejo Superior de Investigaciones Científicas, 2011.

LABORDE, Elga Pérez. El sueño como lenguaje en la poética de Borges. Disponível em: $\mathrm{http} / / /$ www.antoniomiranda.com.br/colaboradores/elga_laborde_borges.pdf. Acesso em: 20/03/2016.

LAMEGO, Valéria. A combatente: educação e jornalismo. In: Ensaios sobre Cecília Meireles. São Paulo: Editora Humanitas, 2007.

LIMA, Luís Filipe Silvério. O Império dos Sonhos: narrativas proféticas, sebastianismo \& messianismo brigantino. São Paulo: Alameda, 2010.

Sueño y misión en el Padre Vieira. In: Los sueños en la cultura iberoamericana (siglos XVI-XVIII). Sevilla: Consejo Superior de Investigaciones Científicas, 2011.

LIMA, Luiz Costa. A Antiphysis em Jorge Luis Borges. In: Mímesis e modernidade: formas das sombras. São Paulo: Paz e Terra, 2003.

LÓPEZ, Pablo Javier Pérez. La poesía como originariedad originante. In: Filosofía y Literatura: Diálogo recobrado. Madrid: Editorial Manuscritos, 2013.

LOUNDO, Dilip. Cecília Meireles e a Índia: viagem e meditação poética. In: Ensaios sobre Cecília Meireles. São Paulo: Editora Humanitas, 2007.

LYRA, Pedro. Ciência, Filosofia e Arte. In: Os Contrapontos da Literatura. Petrópolis: Editora Vozes, 1984.

MACHADO, Álvaro Manuel; PAGEAUX, Daniel-Henri. Da Literatura Comparada à Teoria da Literatura. Lisboa: Editorial Presença, 2001.

MAGALHÃES, Antonio. Partilhas do saber. Diálogos entre filosofia e literatura. Revista Páginas de Filosofia, v1, n.2, 47-59, jul/dez 2009. Disponível em: https://www.metodista.br/revistas/revistasims/index.php/PF/article/viewFile/1479/1565. Acesso em: 28/11/2015.

MATEOS, Zulma. La filosofia en la obra de Jorge Luis Borges. Buenos Aires: Editorial Biblos, 1998. 
MEIRELES, Cecília. Poesia completa / Cecília Meireles. Rio de Janeiro: Nova Fronteira, 2001.

Escolha o Seu Sonho. Rio de Janeiro: Editora Record, 1996.

O Diviníssimo Poeta. Revista Para Todos. Rio de Janeiro, nº 262, 22/dez/1923,

p.49.

MELLO, Ana Maria Lisboa de. Poesia e Imaginário. Porto Alegre: Editora da PUC-RS, 2002.

A poesia metafísica no Brasil. In: A poesia metafísica no Brasil: percursos e modulações. Porto Alegre: Libretos Editora, 2009.

MENESES, Adélia Bezerra de. As portas do sonho. São Paulo: Ateliê Editorial, 2002.

MORA, José Ferrater. Dicionário de Filosofia (vol. 4). São Paulo: Edições Loyola, 2001.

MURCHO, Desidério. Todos os sonhos do mundo e outros ensaios. Lisboa: Edições 70, 2016.

NETO, Miguel Sanches. Cecília Meireles e o tempo inteiriço. In: Poesia completa / Cecília Meireles. Rio de Janeiro: Nova Fronteira, 2001.

NITRINI, Sandra. Literatura Comparada: História, Teoria e Crítica. São Paulo: Edusp, 2010.

NUNES, Benedito. No tempo do niilismo e outros ensaios. São Paulo: Editora Ática, 1993.

OLIVEIRA, Gisele Pereira de; SINGH, Udaya Narayana. A "Pastora das Nuvens" e o "Sol: Cecília Meireles em diálogo com Rabindranath Tagore e o pensamento indiano em prosa e poesia. In: Cecília Meireles em diálogos ressonantes: 50 anos de presença em saudade (1964-2014). São Paulo: Scortecci, 2014.

PALMA, Dante Augusto. Borges.com: la ficción de la filosofía, la política y los medios. Buenos Aires: Editorial Biblos, 2010.

PAREYSON, Luigi. Os problemas da estética. São Paulo: Martins Fontes, 1997.

PERRONE-MOISÉS, Leyla. Literatura comparada, intertexto e antropofagia. In: Flores da Escrivaninha. São Paulo: Companhia das Letras, 1990.

PIZARRO, Ana. Introducción. In: La Literatura Latinoamericana como proceso. Centro Editor de América Latina, Buenos Aires, 1985.

PLATÃO. Teeteto. Lisboa: Edição da Fundação Calouste Gulbenkian, 2010.

PRIETO, Martin. Breve historia de la literatura argentina. Buenos Aires: Editorial Taurus, 2011.

REMAK, Henry H.H. Literatura comparada: definição e função. In: Literatura Comparada: textos fundadores. Rio de Janeiro: Rocco, 2011.

ROSE, Sonia; SCHMIDT, Peer; WEBER, Gregor. Sueño, mentalidades y representación en la Iberoamérica virreinal. In: Los sueños en la cultura iberoamericana (siglos XVI-XVIII). Sevilla: Consejo Superior de Investigaciones Científicas, 2011.

SABIK, Kazimierz. La problemática del sueño en el teatro español de la segunda mitad del siglo XVII. In: Associazione Ispanisti Italiani, Sogno e scrittura nelle culture iberiche. Roma: Bulzoni, 1998. 
SARLO, Beatriz. Borges: un escritor en las orillas. Madrid: Siglo XXI de España, 2007.

SCHOPENHAUER, Arthur. O mundo como vontade e representação. São Paulo: Editora Unesp, 2013.

SISKIND, Mariano. Deseos cosmopolitas: modernidade global y literatura mundial en América Latina. Buenos Aires: Fondo de Cultura Económica, 2016.

SOUZA, Roberto Acízelo. Iniciação aos estudos literários. São Paulo: Martins Fontes, 2006.

STEINER, George. Nenhuma paixão desperdiçada. Rio de Janeiro: Record, 2001.

TRUEBA, Teresa Gómez. El sueño literario en España - Consolidación y Desarrollo del Género. Madrid: Ediciones Cátedra, 1999.

UREÑA, Max Henríquez. Breve historia del modernismo. Cidade do México: Fondo de Cultura Económica, 1978.

VIEIRA, Padre Antônio. Xavier dormindo e Xavier acordado. Lisboa: Miguel Deslandes, 1694.

YOUNES, Ebethal. Jorge Luis Borges y el patrimonio filosófico oriental. Revista Variaciones Borges. Pittsburg: University of Pittsburgh, 1996, Volume 2, p.87-99.

ZAMBRANO, María. Filosofía y poesía. Cidade do México: Fondo de Cultura Económica, 2006. 